\title{
Proceedings of the 7th Annual Meeting \\ on Laboratory Animals
}

(Wakayama, Oct. 6-7, 1972, )

第 7 回実験動物 研 究発表会

（昭 和 47 年 10 月 6 日・ 7 日）

和歌山県民文化会館

**プログラム**

挨 拶会 長 松 下 宏(和歌山医大)

特別講演 疾患モデルと実験動物 大阪大学教授 山 村 雄 一

種之系統

座 長土川 清 (遺伝研)

1. マウスの 2 系統とそれらの交雑子孫における産子数の変化

○伊藤雅夫（日大・医）, 窪道護夫 (動薬検), 猪 貴義 (家衛試)

2. 近交系マウスにおける産子数選抜の効果について

猪 貴義, ○北 德 (家衛試)

3. 共通祖先 (dd) から分離育成された DDD 系, DSD 系の繁殖能力の比較

○猪 貴義, 三浦克洋, 今村憲吉, 北 德 (家衛試)

4. 共通祖先（dd）をもつ 2 近交系マウス（DDD，DSD）における妊娠中の乳腺発育之，下垂体および胎盤性 mammotropin 量の差について

○長沢 弘, 矢内玲子, 宮本盛吉（国立がんセンター），猪 貴義（家衛試）

座 長 江 崎 孝三 郎（害中研）

5. DDY マウスにみられる尾曲りとその遺伝様式

○中野健司, 山本碩三, 黒沢重利, 沓掛源四郎, 今泉 清 (予研),

藤本政晴, 宮本盛吉（国立がんセンター）

6. 歩行異常マウスの発見と維持

○織田銑一, 近藤恭司 (名大・農)

7. ネズミ鞭虫の人為感染率が高いマウスの系統

影井 昇 (公衆衛生院), ○土川 清 (遺伝研)

8. 臼歯欠如に関するマウス KYF 悪系間差異

○土川 清, 原田和昌 (遺伝研), 土川琴代（伊豆聥信病院）

9. ベンツピレン水酸化酵素とマウスの系統差

渡辺民朗（東北大・抗研） 
座長猪貴義（家衛試）

10. 腸炎菌感染に対して均一高度感受性の DKI 系マウスに, 比較的抵抗性の $\mathrm{C} 3 \mathrm{H} / \mathrm{He}$ 系の遺伝子を導入した coisogenic 系統の育成実験 第 3 報

牛場大蔵, 岸本好雄, 斉藤和久, ○前田良三 (慶大·医),

江崎孝三郎（実中研）

11. 実験感染におけるマウスの系統, 週令差による菌感受性の変動

○五島瑳智子, 上村利明, 堂ケ崎勲, 桑原章吾（東邦大・医）

西田 実 (藤沢薬品・中研)

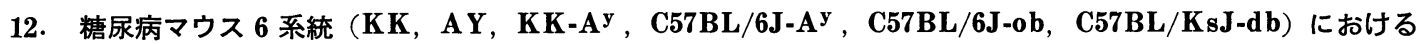
糖尿病症状の比較

西村正彦（和歌山医大 ・応医研）

13. Alloxan に対する ICR 系マウスの糖尿発症について

猪 貴義, ○今村憲吉 (家衛試), 伊藤雅夫 (日大・医),

角田美知枝（日大・農獣医）

座長山田淳 三(放医研)

14. 市販の Wistar 系ラットより育成した近交系（WT-1)，第 1 報 育成途中

○高橋久英, 植 富蔵, 藤平栄一, 仲沢政雄 (大正製薬)

15. 核黄㾝症ラットの繁殖力ならびに産仔数の減少

○棚瀬久雄，鈴木善雄（三共・中央研）

16. Wistar, Buffalo との比較における MP の行動特性一open field における自発的行動一

○辻敬一郎 (名大・教養), 西村正彦 (和歌山医大・応医研)

17. 市販 Hartley-F モルモットにおける移植免疫反応

○高橋 宏, 三浦 馨, 橋本達一郎, 室橋豊穂 (予研・結核部)

依田八治（予研・獣疫部）

$$
\text { ノーマル・データー }
$$

座 長奥木実（都立老人総合研）

18. ウィスター今道系ラットの胎生期およひ哺乳期の成長に関する研究 (I ) 体重および藏器重量 ○塩田尚三，杉山 修（中外・綜合研）

19. ウィスター今道系ラットの胎生期および哺乳期の成長に関する研究 (II) 化骨核の出現時期と化骨化の推移 ○杉山 修, 塩田尚三（中外・綜合研）

20. 高齢（生後 2 年以上）Wistar-Imamichi Rat の解剖所見ならびに臟器重量について

上松嘉男, 若藤靖匡, 川西宏明, 藤田博文, 古沢優子, 斉藤キミ子,

毛利弘子, 筏井 洋, 田内清憲, 鈴木勝士, ○五十嵐章之, 須藤环雄（動繁研）

21. 高齢（生後 2 年以上）Wistar-Imamichi Rat の血液生化学的検查ならびに血液生化学的検討

土松嘉男, 若藤靖匡, 川西宏明, 藤田博文, 古沢優子, 斉藤キミ子,

毛利弘子, 筏井 洋, 田内清憲, ○鈴木勝士, 五十嵐章之, 須藤环雄（動繁研） 
座 長 佐 藤博 (佐々木研)

22. ラットの老化に関する研究 I . 死亡率, 臓器肉眼所見および藏器重量について

○飯塚 壮, 渡辺満利，小堀ナホ，田中寿子（実中研）

23. Sprague-Dawley-JCL 系ラットの長期飼育の一経験

○西部忠幸, 橋本喜信（日本曹達・生科研）

螺良義彦（奈良医大）

24. Sprague-Dawley JCL ラットの加令にともなう諸変化 I . 体重および生理值

○小林孝好, 笠井一弘, 梁川嘉子, 坂口 孝（ヘキスト・ジャパン）

25. Sprague-Dawley JCL ラットの加令によもなう諸変化 III. 病理組織学的変化

○笠井一弘, 重栖幹夫, 小峰作次, 坂口 孝（ヘキスト・ジャパン）

座 長 㴶 道 護 夫（動薬検）

26. Chinchilla の繁殖について

○遠藤 克, 西川滇八 (日大・医)，相馬広明（東京医大）

佐久間勇次 (日大・農獣医)

27. 幼若および成熟イエウサギ（Japanese White Nibs）の心電図 pattern ならびに測定值について

○小林春男, 荒井 研, 赤堀文昭（麻布獣大）

梅沢英彦（日生研・実動研）

28. 実験動物の繁殖 cycle における血液検査成績一ウサギについて

辻紘一郎, ○田村博志, 小島 操, 中村勝美（中外・綜合研）

サ ル

座長本庄重 男 (予研)

29. 組織化学的方法によるアカゲザルの排卵期の推定

○谷岡功邦，泉山絅子，緒方孝康，小泉 均（実中研）

30. ニホンザルオスの性成熟及び生殖機能の季節変動

和 秀雄 (日本モンキーセンター)

31. アカゲザルの血液形態的, 生化学的所見の 5 カ年間の観察結果について

○黑沢和雄, 松島松椊, 阿部栄四郎, 佐々木喜一郎, 柳沢 正, 小沢小市, 武重恒一（日本農村医学研）

32. 実験室内で繁殖，育成したカニクイザルの血清蛋白分画について

○川西康夫 (東西), 本庄重男, 長 文昭（予研）

座 長 由 利 男(日本モンキーセンター)

33. 育成カニクイザルの成長について

○長 文昭, 藤原 徹, 吉岡幸雄, 中山 満, 本庄重男 (予研)

34. 妊娠カニクイザルの血液諸性状

○藤原 徹, 須崎百合子, 矢部美機子, 吉岡幸雄, 栗原金治, 本庄重男（予研） 
35. 乳幼児のモデルとしての仔ザル（カニクイザル）の人工飼育実験

○畠山富而, 若生 宏, 上原充郎, 和田幸子 (岩手医大), 本庄重男, 藤原 徹, 長 文昭 (予研)

36. 前面可動㣣体式サルケージについて

○長 文昭, 小川房雄, 本庄重男 (予研)

37. 輸入ザルにおける下梸の出現状況と治療

○高阪精夫, 本庄重男, 諸田 栄, 加園武芳, 阿部宣子, 中条江美子（予研）<smiles>[Tl]</smiles>

座長倉 益茂 実(日生研)

38. ニホンウズラの血球抗原に関する研究 1 . “K”疑集原に関する研究 水谷 誠（日生研·実動研）

39. ニワトリのコクシジウムに対する感受性について （1） Eimeria tenella およひ E. acervulina による 発病回復の過程について

○及川 弘, 川口陽資, 吉田英子, 奥沢良子, 峰下銕雄（塩野義・油日）

40. ニワトリのコクシジウムに対する感受性について $\quad(2)$ 産卵鶏白色レグホンの銘柄間の差について ○及川 弘, 川口陽資, 吉田英子, 奥沢良子, 峰下銕雄（塩野義・油日）

$$
\text { 疾病と異常 }
$$

座長坂 口孝（ヘキスト・ジャパン）

41. KK マウスの離乳時体重と高血糖発症との関係

○嶋川幸三, 古野厚次, 松尾隆夫（武田薬品・中央研）

42. 肥満マウスの $\alpha$-glycerophosphate generating enzyme について

○小林克裕, 松下 宏（和歌山医大）

43. 䢙伝性筋萎縮症マウスのクレアチン代謝異常について

辻 繁勝, ○大亦順子, 保田龍男（和歌山医大）

44. ビタミンE欠乏飼料給与マウスにおける胎児の異常形態について

中村経紀，○村田義彦（麻布獣大）

座 長螺 良 義 彦（奈良医大）

45. 岡山大学医学部マウスコロニーにおける近交系マウスの自然発生瘇㽾について

○藤田 甫, 有吉佐代子（岡大・医）

46. 20-M Cによるラットの皮ふ癌発生について

○長瀬すみ, 佐藤 博, 長谷川明（佐々木研）

47. 前立腺癌モデルとしての Shionogi carcinoma 115 について

○峰下銕雄（坫野義・油日）, 山口健二（塩野義・研）

松本圭央（阪大・医） 
48. 腫垢像の変化からみた DSD, DDD 系マウスの Estradiol に対する反応性 本間怱太 (家衛試)

座 長藤 原 公 策 (東大・医科研)

49. マウスの乳仔下痢症に関する疫学的研究

○山本碩三，中川雅郎，田名網らみ子，佐味慎三，木口一朗（予研）, 木下邦明 (船橋農場)

50. ラットにおける HVJ の疫学的調查

○牧野 進, 瀬古彰司, 中尾博之, 三日月勝見, 亀井幸雄（塩野義・油日）

51. HVJ 污染マウスコロニーにおけるウイルスの存続様式

○岩井 浤, 伊藤豊志雄, 山中順子, 石原保子 (実中研)

52. Mycoplasma pulmonis と HVJ のマウス肺炎起炎性に関する研究

○斉藤 学, 山本碩三, 武藤 健, 中山一栄, 佐味慎三, 中川雅郎 (予研)

座 長武藤健 (予研)

53. ウサギにおける気管支敗血症菌感染の疫学的調査研究

○依田八治, 中山一栄, 遊佐智栄, 松本幸蔵, 渡辺幹男, 中川雅郎（予研）

54. ウサギ Tyzzer 病の自然発生

○来原兄忠, 寺内 淳 (日本メルク万有)

55. ウサギの趾踵部炎症に関する研究 I. 発生, 経過について

○野口午郎, 二木力夫, 内山智晴, 宇佐美正義, 佐藤忠夫, 高垣善男（中外 - 綜合研）

座長中川雅 雄 (予研)

56. ラットにおける Tyzzer 病の自然発生例について

○武藤 健, 中川雅郎 (予研), 藤原公策 (東大・医科研), 平賀興吾 (都衛研)

57. Wistar 系ラット集団にみられた野鼠との交雑と思われる一事故例について

○山田淳三, 山崎友吉（放医研）

58. 市販 clean マウスの放射線関係実験への適用について

○北爪雅之，山田淳三，土屋武彦（放医研）

座長 今 泉 清 (予研)

59. ラットの消化管内細菌に関する検索 1. 発育期における細菌数の変化

○餅田久利, 田内美代子, 炭䆮鏡子, 田中輝彦（エーザイ・生物研）

60. バリヤー内で人工哺育したラットの腸内菌叢の定着について

○中尾博之, 瀬古彰司, 牧野 進, 三日月勝見（塩野義・油日）

61. 最近 3 年間における市販実験用動物（主としてマウス・ラット）の寄生虫検査成績

○田中英文・藤波不二雄, 大島 慧（田辺製薬・生物研） 
62. モルモットにおけるコクシジウム感染による原虫相の変化

武藤 健, 杉崎正雄 (予研), ○白鳥耕也（資生堂・研）

\section{実験手技}

座 長 長 瀬す み(佐々木研)

63. マウス，ラットの屠殺法についての一考案

○谷口芳信 (日本クレア), 高橋 弘 (実中研)

64. 小動物における採血方法の検討 第二報, 尾静脈採血法

○矢島隆二, 後藤鋼星, 水上浩司、(ヘキスト・ジャパン)

65. シロネズミの新しい固定法と頸静脈連続採血法

$\bigcirc$ 金武朝春, 瀬井康雄, 茶川清二 (涌永薬品・中央研)

座長山内忠平（実中研）

66. 朣外見所見を利用した妊娠ラットの確保，スメア法と比較した交配率と作業勃率

○田中光夫，児玉直己，江角吉造（日本シェーリング）

67. ラットのヒフ移植試験法の比較検討

○前田甚作，豊島久美子，原田喜男（塩野義・研）

68. ラットの甲状腺機能検査のための Triosorb Test

○樽本保男，斉藤修司，仲沢政雄（大正製薬）

施

設

座 長佐 藤 善一(日本クレア)

69. 実験動物飼育施設の環境調査, II．F生育場

○高橋 弘, 米山敏子, 佐藤悦子, 今井都泰 (実中研),

谷口芳信, 田口福志（日本クレア）, 嶋本洋二（日東理科工業）

70. 実験動物飼育施設の環境調査，III． I 生育場

○山内忠平，平山三船（実中研）, 谷口芳信（日本クレア）

71. 実験動物飼育施設の環境調査一 $\mathrm{I}$. 国立公衆衛生院 SPF 動物実験施設

○吉沢 晋, 山崎省二 (公衆衛生院), 滝沢隆安 (家衛試)

72. 国立ガンセンターにおける実験動物飼育方式の改善について

○藤本政晴, 宮本盛吉, 長沢 弘, 榑谷和男（国立がんセンター）

73. 実験動物施設の環境統御 一シャワー廃止とその影響について一

○久保文雄, 加藤法子, 高橋徳太郎, 務台方彦, 代田 稔（ヤクルト研） 
生産 と管 理

座 長 鈴 木 善 雄 (三共製薬)

74. オートクレーブ滅菌が飼料の消化・吸収に及ぼす影響について

○山中聖敬, 斉藤宗雄（実中研）

75. 東大医科研・実験動物センター 4 階に設置されたオートクレーブによる器材の滅菌に関する検討

○前島一淑，鈴木 潔，小林理造，須藤力ツ子，伊藤喜久治（東大・医科研）

76. Pathogen Free Rabbits $の$ 育成

○多賀谷修, 松原孝雄, 餅田久利, 橋本茂樹, 田中輝彦 (エーザイ・生物研) 木村 克, 鈴木四郎, 脇田隆治, 野崎良美 (カワシマ商事)

77. 残留農薬研究所動物実験棟における空中細菌についての検査成績

○高橋和明, 古橋彰子, 大沼富雄, 坂本年夫, 白須溙彦 (残留農薬研)

座長鈴木潔（東大・医科研）

78. 日生研におけるウサギ (JW-NIBS) の生産について 梅沢英彦, 由井福男, ○矢沢 筆, 倉益茂実 (日生研・実動研)

79. 精製飼料によるマウスの飼育・繁殖について（I）

○岩田寿雄, 三鴨信秋, 北村佐三郎（オリエンタル酵母）

80. 系統マウスの繁殖成績と計画生産についての一試案

○宮本盛吉, 長沢 弘, 藤本政晴（国立がんセンタ一）

座 長 川 俣 順一（阪大・微研）

81. 久留米大学医学部動物実験センターの管理運営について

○野田安孝, 山田誠哉（久留米大・医）

82. 動物実験センターにおける施設点検の実際とその結果

野田安孝, ○田中智久, 稲吉三男 (久留米大 · 医)

83. 和歌山医大 ・実験動物センターのその後の運営について

○西村正彦, 辻 繁勝, 松下 宏 (和歌山医大)

84. 電子計算機によるマウスの飼育管理について 第 2 報

藤崎年英（和歌山医大）

座 長 中 村 経 紀（麻布獣大）

85. マウス交配時の雄雌同居最適比率について

○野崎良美（カワシマ商事）, 田中輝彦（エーザイ・生物研）

86. マウスの反復過排卵誘起

石島芳郎（東京農大）

87. 昼間飲水率からみた不適照明時間の限界

村上宏（神戸大・医） 
88. ハムスターの性周期に及ぼす光の影筫一夏期における照明条件の検討

中野健司, ○沓掛源四郎, 今泉 清 (予研)

89. 実験動物と騷音 V. 騷音環境で飼育したラットの体重およひ採食, 飲水量について

$\bigcirc$ 今井都泰, 高橋 弘（実中研）

ヌ

座長及川弘（塩野義・油日）

90. 実験用 Beagle の眼底について 第 2 報 色素欠乏症犬に関する観察

○福井正信, 安達二朗, 赤池 勇 (中外・綜合研)

91. 実験用 Beagle に関する基礎的研究一繁殖コロニーにみられた疾病について

辻紘一郎, ○常井和男, 神津正光, 真貝 博, 富永 聰 (中外・綜合研)

92. イヌの甲状腺炎について

○二木力夫, 高垣善男, 福井正信, 富永 聰（中外・綜合研）

93. ピーグル繁殖コロニーにおけるジステンパーの大量発生について

O久木田禧一, 岩城隆昌 (日本E D M), 山内忠平 (実中研)

座 長辻紘一郎 (中外・綜合研)

94. 実験用 Beagle の歯牙の磨耗について

福井正信, ○赤池 勇, 安達二朗 (中外・綜合研)

95. 犬の無麻酔下カテーテル採尿法

○東山 昇, 中田勝久, 山口健二（塩野義・研）

96. 自家繁殖 Beagle 犬の血液諸検查值

○内海健二朗, 深川清二, 鶴田耕右, 大西久美雄, 辰巳 熙 (大日本製薬 - 総合研), 野田周作（大阪府大・農） 


\section{* * 抄}

\section{特別講演 疾患モデルと実験動物}

山村雄一（大阪大学）

田嶋博士によると,「実験動物とは研究に重要であると して飼いならされ，合目的々に繁殖，生産される動物」 といらふらに定義されている。ここで私が問題にしたい のは合目的の内容に「人間の疾患」のモデルを加えたと きのことである。

Russel らによると，実験動物はまず遺伝子型によっ て規定されるが，受精から出生までの胎児としての発育 や出生後哺乳時の環境によって規定されて一つの表現型 をとり,さらにその後の動物育成の場と実験の場として の近隣環境によって規定されて演出型となるという。し かしこの演出型のみで人間の疾患モデルをカバーできな いことは当然であって, 実験動物の環境条件が整備され るほど遺伝子型の影響が強くあらわれ，遗伝子の異常に よる疾患モデルの研究には適当であるが，その他の疾患 モデルの研究には不充分である。

疾患モデルを実験動物に求めるためにはいくつかの条 件を満す必要がある。

第 1 にその疾患が人間のものとよく似ているための動 物種の選択を行うことである。動物種についてはどのよ らに努力しても所詮人間との差を埋めることは不可能で ある。つまり部分的相似性にとどまる。その上でさらに 疾病としての相似性を追求する必要がある。そのために は動物種に関する研究のみではなく，人間の疾病に対す る認識をたかめる必要がある。

実験動物はしばしば試薬に例えられるが，両者の間に は大きな差異があることをみとめ，その認識の上に立っ て実験動物の研究を行ら必要がある。すなはち(1)純度の 内容に大きな差があり，(2)用に臨んで同一物を任意の量 つくることができない。(3)試薬は誘導体を任意につくれ るが動物では難かしい。高血圧ラットや糖尿病マウスが 誘導体に当るのかも知れないが，(4)試薬の变質は困る が，疾患モデルでは動物の疾患が欲しい。などの大きな 差がある。

第 2 亿実験動物を放置して扬いて疾患を発生するとい らだけにとどまらず，一定の処置を加えて疾患をつくり 出すことが要求される。

しかもそれは人間の咨患にきわめて相似して和り，そ の発生の率が高いことが要求される。

第 3 にベッドサイドの実験から矢患の問題点をとら え, 実験動物に移してモデルとして問題を解決し, 再び これをべッドサイドにかえすことが理想である。
そして最後に実験動物抜きのヒトからヒトの疾患を類 推できないか，その可能性を検討することも忘れてはな らない。

第 1 の人間の疾病に似た動物種の選択については, 例 えば肥満マウス, 糖尿病マウス, 高コレステロール血症 ラット，筋萎縮症マウスなどや実験的腫瘍があげられ る。わが国で維持されている可移植性腫瘍は1971年度で マウスで73, ラットで51系統もあり, ラット腹水肝癌の 株だけでも90株, 吉田肉腫で39株という多数にのぼって いる。しかしこのなかから人間の腫瘍に最も相似してい る株はどれか, 人間の癌の治療に有効な抗癌物質を探す にはどの株が最適であるのか。明快に答えることはむつ かしい。

そこで積極的に動物に処置を加えて人間の疾患に似た ものをつくる必要がおこる。その例としては動物の微生 物による感染やわれわれが作ったウサギの実験的肺癌を あげることができる。

結核の化学療法が進歩した現在では, 結核性空洞が結 核の臨床で最も困難な問題となっている。われわれはま ず動物（ウサギ，サル，モルモットなど）の肺に空洞を つくる試みからはじめた。そしてこの空洞作製法によっ て結核の乾酪性壞死や空洞は, 結核菌の蛋白またはりポ 蛋白を抗原とする遅延型アレルギーがひき金となってい ることを明らかにした。強力な化学療法剤に抵抗して空 洞が今もな数多く残っているわけも明らかとなった。 さらに結核菌から分離したツベルクリン活性をもつペプ チドや蛋白の静脈内注射や，免疫抑制剤のイムランや 6ーメルカプトプリンの 投与によって空洞形成が予防さ れた。そこで果してイムランが空洞発生予防作用を持つ かどらかをしらべたとところ, 動物実験と全く異り, 何 らの臨床効果もみとめられなかった。

実験動物を妨きにて人間の疾病のなりたちにメスを 入れ，さらにそれが分子生物学全般にも大きな影響を与 えている場合も少なくない。例えば免度グロブリンにお けるミエローマ蛋白の研究, 赤血球の生理と病理に和け る異常へモグロビンの研究などである。

また, 人間の先天性代謝異常が他の一般的な代謝病の モデルとなったこともある。例えばLesch-Nyhan 症候 群の病因がグアニンやヒボキサンチンの回収経路の欠損: にもとづくことが明らかになり，その後痛風患者の数パ 一セントに扔いて同じ経路に部分的欠損が存在すること がわかった。前者の先天性遺伝性代謝異常が痛風の疾患 モデルとなった例である。この例は疾患モデルが人間で 成立し，人間以外の動物でなくてもよいことを示してい 
る。

疾患モデルとして実験動物をとりあつからとき, 従来 の方法に加えて, (1)もっと実験者が人間の疾患の実態を 十分にとらえて拈くこと，(2)実験動物につくられた疾患 モデルが果して人間の疾患とどれだけの相似性をもって いるかをさらに十分に検討する。そのためには動物の臨 床医学ともいうべきものが必要である。(3)実験動物ぬき の人間同志の疾患モデルは考兄られないかなどを考慮す ベきであろら。

いずれにせよ人間または動物の疾患モデルを考えると きには一定の問題意識を明らかにする必要があろう。 [発言]

坂口 孝(ヘキスト・ジャパン) 動物実験を行らも のとして, 疾患モデルとして実験動物を用いて研究を行 う場合, 安易な態度をさけるべきだと思いますが，臨床 医学の立場より我々動物実験を行ら者が心得えて拉かね ばならぬ限界について打教え頂きたいと思います。

河合清之 (労衛研) 1 . 代謝疾患異常の原因という ものは, どらいうふらに考えてよいものでありましょう か?。2. もしかりになんらかの原因を考虑するとき に, 遺伝的代謝異常再現を実験的に再現するアプローチ は必要となる可能性はありませんでしょらか? 。

\section{種亡系統}

\section{1. マウスの 2 系統とそれらの交雑子孫における産子数 の変化}

○伊藤雅夫（日大・医），洼道護夫（動薬検）, 猪 貴義（家衛試）

〔目的〕遺伝的に制御された実験動物の 1 つとして, 交雑群，とくに近交系間の交雑 $F_{1}$ は, 遺伝的変異が近 交系と同様に小さい事，環境の変動に対する自己調節機 能は近交系に優っていると云われている事などから，近 年実験動物としてのその重要性が注目されている。演者 らは，GTH の反応性についての遺伝的要因を知る一過 程に执いて, DDK と C $57 \mathrm{BL} / 6$ 系との間で交雑試験を 行う必要から, 両系統間で Reciprocal に交雑子孫を作 出した際，C57BL/6 系を合にした交配組合せの場合に 和いて, 妊娠率の低下と, 顕著な産子数の低下が観察さ れた。従来から, DDK の早は他系統との間に子孫が取 りにくいと云われて打り，系統の特性の1つにあげられ ているが，今回の成績では，DDKの早の要因に加党 て， C57BL/6 の今を用いた事が，“側の要因として加 味されている事が示唆されるものであった。この事は, 交雑群作出に拈ける問題点として興味深い点と思われる ので報告する。

〔成績〕 DDK，C57BL/6 系における，系統内で交配
した場合の産子数は, DDK で $5.28, \mathrm{C} 57 \mathrm{BL} / 6$ で 8.09 であった。2 系統間で $\mathrm{F}_{1}$ を作出する場合, $\mathrm{DDK}$ ( 早) $\times$ C57BL/6（合）の交配組合せに拈いては，3/28 が分婏に

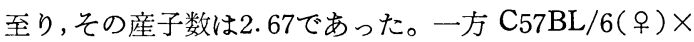
$\operatorname{DDK}(\hat{0})$ の組合せでは 10/12 が分婏に至り，その産子 数は7.80であり，DDKの 早に他系統の方を交配した場 合に産子が得にくいといら従来の報告によく一致する成 績であった。さらに，得られた $F_{1}$ の早を用い，交配令 を $\mathrm{F}_{1}, \mathrm{C} 57 \mathrm{BL} / 6, \mathrm{DDK}$ と変えた場合，産子数は交配組 合せの違いにより有意に変化することが認められ，特に C57BL/6 系の文を交配した場合に沶いて，産子数が著 しく低下することが認められた。また， DDK( 早)×

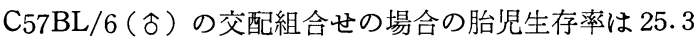
\%であり，DDK の系統内交配の場合の $62.2 \%$ と比べ有 意に低い成績であり, 排卵数, 着床数に打いても有意に 低いことが認められた。

\section{[発言]}

江崎孝三郎（実中研） 今回の発表に関連した報告が ありますので追加致します。1つは，富田の報告でD D $\mathrm{K}$ 古 ×他系占での産仔が減少すると云うものである。

他の 1 つは若杉の報告で, この産仔数の減少が早期の 胚死亡によるものであり, かつ，受精 $3 \sim 4$ 日の異常卵 割が肧死亡の原因である，と云うものである。

吉田元一（信大・農） 実験マウスの飼育方法につい て御説明下さい。とくに妊娠期に拈ける雌雄マウスの同 居について。

高橋和明（残留農薬研） 着床前のロスの原因の一つ として雄の二オイの影響が考えられませんか。

近藤恭司（名大・農）名大(農)でも, C $57 \mathrm{BL} / 6$ を用 いて同様な結果をえました。卵巣移植実験を行って，こ の $F_{1}$ 胚の死亡は, 子宮と胚との関係から怙さるもので はなく，卵の方に原因のあることがわかり，その「異常 を抗こす性質」は，遺伝子によって遺伝しているもので あることが，わかってきました。

土川 清（遺伝研） D D K 雌とC57 B L 雄のほか, ぞの系統の雄との交配でも同様の現象がみられますか。

伊藤雅夫（日大·医）吉田への解答：우 3 に対し今 1 の割合で交配し，腟栓確認後も，分娩直前まですと同 居させておいた。これは生産の場でのデータなのでこの 様な条件になったのである。

高橋への解答 : 着床前のロスの高い事の原因は本実験 の段階では明確に答えられないが, $\operatorname{DDK}($ ㅇ $) \times \mathrm{C} 57 \mathrm{BL}$


合に比べ有意に低くかった事から，子宮と胚との関係等 遺伝的な要因の他に，ヘロモナルな要因が関与している ことは，充分考りょしなければならないと思われる。 土川への解答 : 現在まで数系統間で同様の試験を行っ 
ているが，同様の現象がみられる組合せと，否定される 組合せの両方がある。現在まで, CEW ( ㅇ ) と C57BL/6 (合)との交配組合せで，肧死亡が高くなる事が認められ ている。

\section{2. 近交系マウスにける産子数選抜の効果について}

猪 貴義, ○北徳 (家衛試)

近交系マウスの維持に括いて，その特性，均一性等の 長期間にわたっての維持は重要であるが，その使用目的 から, 高い繁殖能力の保持, 低下した繁殖能力の回復增 進はさらに重要な課題である。すでに確立された近交系 の遺伝的変異は，理論的に極めて小さく，選抜の効果は 得られない事が予測されるが，近交系に拈ける繁殖能力 選抜が有効か否かの検討は重要と思われるので，確立さ れた近交系に拈ける 産子数選抜の 効果について 検討し た。

用いた系統は， $\mathrm{C}_{3} \mathrm{H} / \mathrm{He}, \mathrm{C} 57 \mathrm{BL} / 6, \mathrm{NC}, \mathrm{KK}$ であ るが，C3H/He，C57BL/6は，1950年代にわが国に輸入 され，1963年に東大医科研を経て家衛試に導入された。 この両系統は, 医科研では closed colony として維持 されていたが，家衛試では再び兄妹交配を開始した。 NC，KK は，名大より1963年に導入されたが，さらに 兄妹交配を継続している。選抜方法は， C3H/He， C57 $\mathrm{BL} / 6$ には家系選抜， $\mathrm{NC} ， \mathrm{KK}$ には家系内個体選抜と 家系選抜を組合わせ実施した。選抜率はいずれの場合も 約34\%であった。

世代平均産子数では, $\mathrm{C} 3 \mathrm{H} / \mathrm{He}, \mathrm{C} 57 \mathrm{BL} / 6, \mathrm{KK}$ に増 加傾向が，NC に減少傾向が認められた。また，累積選 抜圧, 累積選抜反応とその 関係を示す実現遺伝率は, $\mathrm{C}_{3} \mathrm{H} / \mathrm{He}:+13.0,+1.1,0.08, \mathrm{C} 57 \mathrm{BL} / 6:+7.3$, $+1.2,0.16, \mathrm{KK}:+12.4,+1.1,0.09, \mathrm{NC}:+17.3$, -1.1, negativeとなった。次に, $\mathrm{C}_{3} \mathrm{H} / \mathrm{He}, \mathrm{C} 57 \mathrm{BL} / 6$ に扮いて，選抜による産子数度数分布の変化について検 討した結果, 両系統とも, 最高頻度值が選抜の方向に移 動し, 産子数の多い個体数の増加が認められたが, 分布 の範囲には大きな変化は認められなかった。

以上の結果から，近交系の遺伝的変異は，長期間にわ たって継続された近親交配によって，非常に小さくなっ ているが，近交系に沶いても，産子数選抜によって，あ る程度, 産子数を増加し得る事が示唆されるものと考学 られた。

\section{[発言]}

江崎孝三郎（実中研） 産仔数などは環境の影響を受 ケやすい形質である。世代を重ねることによって動物が 環境になれる点, 人が動物の性格を怙ぼえる点, 飼育管 理の改善などの点; これらの影響が大きいのではない か。
北徳(家衛試) これまでのが知られており, 産 内外の報告によると, 産仔数の遺伝率は一般に低いこと 仔数の決定には環境の諸要因が大きく影響することが考 えられます。しかし今回報告しましたように,すへて 系統が，まったく同じょらに産子数増加の傾向を示して いるのではなく，NC系に扣いては，環境，管理条件が 同一であるにもかかわらず，産子数が減少傾向を示して おりますので, 今回得られた結果は, 御指摘の環境, 管 理条件のみの影響によるものではなく, 選抜による遺伝 的な結果であると考えています。

山田淳三（放医研） 遺伝的分散が非常に小さいと思 われる近交系で選抜効果が認められているよらですが， これについてどう括考えですか。近交系の規定である 20 代以上といらことも疑問がでてきますが?。

北德 (家衛試) 理論的に近交系は, きわめて遺 伝分散が小さい状態にありますが，選抜の効果が得られ て怙りますので，実際には遺伝分散が残っているのでは ないかと考えています。兄妹交配を20世代継続すること によって, 近交係数 : $98.6 \%$, 近 縁 係数 (血縁係数) : 99.6\%という理論值が得られますが，実際の值は理論值 よりもかなり低いことが示され, 理論值と実際の值は区 別して考えるべきであることが，これまでに，Grünberg, Falconer, 近藤らによって何回か指摘されて来て おります。

\section{3. 共通祖先 (dd) から分離育成された DDD 系, DSD} 系の繁殖能力の比較

\section{○猪 貴義, 三浦克洋, 今村憲吉, 北徳(家衛試)}

わが国に括いては, dd マウスを共通祖先とし, 分離 育成された多くの近交系が維持され，これまでに各種の 研究に使用されてきた。

これらの研究素材を育種という観点からとらえてみる と, 共通祖先から出発し, 作出された近交系の相互間に 特いて，どのような特性がどの程度の範囲にわたって変 化してきているかについて検討することは極めて重要な 意義がある。

今回は, 繁殖能力に拈いて大きい差を生じた DDD(東 大医科研由来, F 45 47), DSD (東北大農学部由来, F 37〜41）の比較成績である。

DDD の産子数は 7.69 0.20 , 哺乳率, 離乳率は約 85 $\%$, 食殺率（親が産んだ子を生後12日令までに全部食べ た腹数／分娩腹数）は $12.0 \%$ ，他方，DSD の産子数は $4.68 \pm 0.38$, 哺乳率, 離乳率は約30\%, 食殺率は64.7\% であり, 両系統間には産子数, 哺乳率, 離乳率, 食殺率 に大きい差がみられた。

DSD の産子数の減少原因については, 排卵数の減少, 
排卵された卵子の子宮着床前の消失，分娩後の新生子の 食殺が他系統よりも多いことが明らかにされ，哺乳率， 離乳率の減少, 食殺率の増加は, 母の泌乳能力の減退に 原因することが推定された。

DDD，DSD の両系統の繁殖能力の差をひき起した育 種的な原因としては，両系統の維持繁殖集団の大きさの 違いにもとづく選抜効果の相違に起因するものと考学ら れた。

[発言]

奥木 実（都老人研） 繁殖集団の有効数はどれくら いでしょらか。

猪 貴義（家衛試） 維持繁殖集団の大きさは，理論 的には，対象とする集団の遺伝的変巽が大きく，遺伝改 良の期待できる選拔初期の時代には繁殖集団を大きく維 持し，選拔世代が進み，集団の遺伝的変異が小さく，遺 伝改良が期待しにくい時期には維持繁殖集団は小さくと もよいと一般に考兄られる。しかし，維持繁殖集団の大 きさは，実際には施設の大きさ，人員，経費などの客観 的な状況によって規制をうける場合が多いが，余りにも 維持繁殖集団を小さくすると有効な選拔が行なわれなく なり，今回の報告のように生産力が低下寸る危険性があ る。

太田秀夫（愛知衛研） マウス繁殖による食殺の原因 として色々要因は考兄られるがその点について教光願い たい。

猪 貴義（家衛試）食殺原因については御指摘の通 りである。ここ $2 \sim 3$ 年, 食殺問題が本研究会に执いて 論議されてきたが，食殺原因として，演者は次のいくつ かの原因を考学ている。(1). 近交退化 (inbreeding depression)——近交世代の増加にともなう能力の低下 一飞よる繁殖, 泌乳能力の低下, (2). 栄養の欠陥, （3）. 管理上の欠宿——親に対する精神的ストレスの負 荷，(4). 母の育子能力の減退一一巣作りの悪いもの, 分 婏後, 乳子をケージ内に散らすものは食殺の傾向が高 い。

\section{4. 共通祖先 (dd)をもつ 2 近交系マウス (DDD, DSD) における妊娠中の乳腺発育と，下垂体およひ胎盤性 mammotropin 量の差について}

○長沢 弘, 矢内玲子, 宮本盛吉（国立 がんセンター), 猪 貴義 (家衛試)

〔目的〕 DSD マウスに护ける育子性低下の原因を検 討する一環として，泌乳にとって重要な要因である妊娠

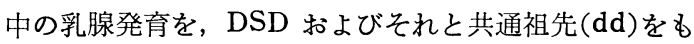
ち育子性の良好な DDD 飞和いて比較し，また妊娠19日 目に怙ける下垂体抢よび胎盤性 mammotropin 量を調 べた。
〔方法】家畜衛生試験場で系統繁殖された DDD およ び DSD を70 日令で交配した。乳腺発育の指標として は; 妊娠14日目に biopsyにより採取した左側胸部第三 乳腺の一部执よび19日目朝供試した際採取した右側第三 乳腺の wholemount 標本による乳腺胞発育度, ならび に妊娠19日目の両側そけい部乳腺の核酸量を用いた。下 垂体中 prolactin, GH 量はディスク電気泳動法により, また胎盤性 mammotropin 量は胎盤の水抽出液を若齢 $\mathrm{C}_{3} \mathrm{H} / \mathrm{He}$ 雌 マウスの 右側胸部第三乳腺皮下に 局所注射 して，その発育度を指標とした。

〔成績〕妊娠14および19日目の乳腺胞発育度, 19日目 の乳腺中核酸量のいずれに扎いても DDD は DSD ょり 有意に大きく，DSD における DNA および RNA は DDD の約 $1 / 2,1 / 3$ であった。妊娠19日目の DDD の乳 腺は完成した乳腺胞系で占められ，多くのものに分泌物 の存在が認められた。一方 DSD の乳腺胞は小さく，そ の発育は妊娠14日目の DDD のそれに相当する程度であ った。下垂体中の prolactin, GH 量は単位下垂体重あ たりでは系統間に差はみられなかったが，全下垂体あた りでは DDD は DSD ょり有意に高かった。胎盤6コあ たりの mammotropin 量は両系統とも同程度であっ た。したがって全体としての量は胎盤数の多いDDDは DSD の約 3 倍で，分泌量にも大きな差のあることがう かがわれた。

[考察]DSD の育子性の低下は, 妊娠中の乳腺発育 やその機能のひくいことによるところが大きく，また刺 激者としての mammotropin 分泌の差が乳腺発育の差 の大きな原因の一つと考兄られた。な拈本実験の詳細は 「実験動物」21(4), 1972 に揭載。

\section{[発言]}

本間䳏太 (家衛試) DSD の泌乳能力との関連を示 す興味ある成績を拝見させていただき有難うございまし た。乳腺発育に関与する因子の中で妊娠の維持にも関与 するものがあると思われます。DSD では妊娠の 維持 はとくに悪くないといわれていますが，この点は下垂体 のプロラクチン分泌能が低いといら先生の成績からどら 考えられるでしょらか。DSD では mammotropin 重 が少いといらことですが, 1 コの placenta 当りでは有 意差はないように見うけました。従って, 乳腺発育に関 しては, むしろ, 乳腺側の反応性の検討が重要であろら と考皇ますがいかがでしょらか。

長沢 弘（国立がんセンター）仰せの通り, 乳腺発 育に関与する因子（ホルモン）は，一方では娃娠維持に 関与しています。乳腺発育には分泌される mammotropin の全体としての量が問題と考えられますので, 乳腺発育に拈ける顕著な系統差は, 下垂体ないし胎盤か らの全体としての mammotropin の分泌量に扣いて 
DSD が DDD より有意に低いことによると考兄らま す。一方, 妊娠の維持には胎子あたりの量がむしろ問題 と思われます。下垂体単位重あるいは胎盤 1 個あたりの mammotropin 量には系統差がなく，また DSD は DDD より胎子数が少ないことを考劣ると妊娠が正常に 維持されることもらなづけるかと存じます。乳腺の発育 には, 刺激者としての mammotropin の量と, それに 対する乳腺の感受性(反応性)が大きな要因です。DDD とDSD 飞打ける乳腺の mammotropin 飞対する感受 性の差を検討することは, 両系統の乳腺発育の差の原因 を追求するために非常に大切なことと存じます。

渡辺民朗（東北大）核酸量を測定するとき, 湿重量 当りの值を示しているのでしょらか。

長沢 弘（国立がんセンタ一）両側そけい部の乳腺 全部を試料として用いましたので, 測定值は “全量”と いらことになります。

吉田元一 (信大・農) 乳腺の発育にみられる差を系 統差と考兄られるか，近交退行と考吕られるか。

長沢 弘（国立がんセンタ一） 現時点においてみれ ば明らかに系統差です。その系統差の原因を考学れば, 近交退化もその一つとしてあげられるでしょら。

\section{DDY マウスにみられる尾曲りとその遺伝様式}

○中野健司, 山本碩三, 黒沢重利, 沓掛源四郎, 今泉 清 (予研), 藤本政晴, 宮本盛吉（国立 がんセンター）

〔目的】兄妹交配で維持されているDDY に尾曲りが 発現した。この形質を紹介すると同時にこの尾椎骨異常 が遺伝的なものであるか否かを確かめるため交配実験を 行った成績について報告する。

〔方法】交配実験は予備実験で劣性遺伝を示唆する成 績を得ているので形の如く交配実験 $\left(\mathrm{F}_{1}, \mathrm{~F}_{2}\right.$ の分離, 戻 し交配）を行ない遺伝様式を検討した。

〔成績〕この異常は尾椎骨の変形による尾曲りであっ て出産直後の新生仔について直ちに彎曲は識別できる。 この尾曲りの度合はまちまちで斉一な形状をとることが ない。更に仔マウスのひげは生後 4 週令までは彎曲して 枯り,ひげの彎曲と尾曲りとは必ず並行しているが 4 週 令を過ぎた頃からひげは正常の直毛に復する。交配実験 では $F_{1}$ と执いて DDY との交配で腹によって尾曲り の出現をみることもあった。ddN, GPCY, C57BL/6, $\mathrm{DBA} / 2$ の諸系統との交配 $\mathrm{F}_{1}$ ではすべてが正常尾であ った。 $F_{2}$ の分離をみると DDY のみが $3: 1$ の分離比を 示し他の系統では示さなかった。戻し交配ではDDYの みが $1: 1$ の比率を示し，他はすべてこの 分離比を示さ なかった。

[考察】以上からこの形質は遺伝子と形質とを明確に
対応させ得るものではなく単純劣性遺伝子による形質の 遺伝とは考它にくい。わが国では近藤教授の日本尾曲 り，その他 Short tail, Fused, Flexed tail などがあ るが，これらのいずれにも属さないのではないかと考光 られる。彎曲の度合は 1 腹中でも様々で 1 つの型に固定 できないこと, 異常の発現が DDY に対してのみ劣性遺 伝様式を示すことから今後この形質の固定と DD 亜系間 での比較を試みたい。

[発言]

山口健二(塩野義・研) 私共も ddNを祖先とする ddSを維持していますがその亜系の 1 つであるC-1系に 曲尾を頻度高く観察しそしてこの系統の雄では闘争が最 も強いことも観察しています。data は只今整理中で す。先生の方ではこの曲尾と闕争の間に関連があるよう な観察はなされたことはありませんか。

中野健司（予研） 私共が報告したDDYにみられた 曲尾マウスでは, 雄の間で特に闘争が烈しかったことは ありませんでした。従って私共の曲尾と闘争との間に関 連はないものと考えて赤ります。

\section{6. 歩行異常マウス (Rolling mouse Nagoya, rol) の発見亡維持}

○織田銑一, 近藤恭司 (名大・農)

〔目的〕乳児死亡が多発するSIIIb系に㨟いて歩行異 常マウスを発見した。この異常は遺伝するという推定の もとに交配実験を行い，その遺伝様式を解析しようとし た。また mutant 系実験動物として育成を試みた。更 に, この例から, mutant 系実験動物育種の体系化を検 討した。

〔結果と考察】交配実験により，この歩行異常 (Rolling mouse Nagoya, rol) は, 常染色体上の単一劣性 遺伝子に支配されていた。症状は 2 週令で確実に判別で き，歩行の際に，よろめき，横転をくり返えす。SIIIb の中では, adult に達するものは極めてまれであったが, 雑種化してみると, 安定してこの mutant の adult を 得ることができた。雑種化したす 早は共に性成熟に達す るが，占を mutant にすると，仔を得ることが困難で あった。古を mutant にとった場合には, 仔を得るこ とができるが, 育仔能力はやや低く, その仔の成長は良 くなかった。 mutant と normal とを同居させると， やはり mutant は成長が悪い。そのため mutant のみ は40日までは親と同居させることがのぞましい。この遺 伝子を保存するために, heterosisを考虑しつつ, C57BL/ 6JNga，C3Hf/HeNga などを用い, cross-intercross system を行っている。

以上を総括してみると, mutant 系実験動物育種の基 本は次の 5 点に要約されよう。(1) mutant gene の保 
存が第 1 の目的であり, gene background の整一化 （近交化）はその次の目標である。 mutant の中には生 存能力が弱いものが多く, そのために heterosisを利用 した交配を考学る必要がある。(2) mutant 系の維持は hetero 型にて行うことを重視する。(3) mutant gene の保存と実験利用との交配では, 必ずしも同一様式には ならない。この時 coisogenic あるいは congenic strainを考光て, 常汪同一 strain から normal と mutant とを得られるようにする。(4)mutant の発見時の事情, 生存抽よび繁殖能力等, 維持交配に関するデータは可能 な限りそろえる。(5)mutant gene の形質発現（どの部 位に，いつの時期に）を正確に把握する。

[発言]

山田淳三（放医研） Mutantを保存する手段として 2 元 3 元で保つことは良い方法と考学ます。しかし実際 に実験動物として使用するには, まだ 2 元 3 元した場合 のデーターが不足して括り, 今後これらの点について集 積して行く必要があると考学ますが。

織田銑一 (名大・農) Mutant 系実験動物育種の目 的は, mutant gene に関する研究扣よびその利用にあ ると考㝋ます。そのため, いかに mutant gene を保存 していくか, といらことが重要になります。 2 元 3 元交 配だけでなく，どのよらな交配様式をとろらと， gene の保存さ光出来ればかまわないと思います。gene の保 存が出来たら兄で, gene background の整一化 (congenic strain や coisogenic strain) を目指すことが望 ましいと思います。尚, その mutant gene を保存する ために，最もふさわしい交配様式を考えること，あるい は, mutant gene をいくつかの近交系に入れて，その 効果を観察することも一つの実験になります。実験動物 として使用する際のことですが，はっきりした mutant 形質を現わす場合や近交化がむずかしい場合には，近交 化しなくても，実験内容方法を兄らぶことによって研究 目的に近づくことが出来るのではないかと考觉ます。

\section{7. ネズミ鞭虫の人為感染率が高いマウスの系統}

影井 昇 (公衆衛生院), ○土川 清 (遺伝研)

ヒトで鞭虫保卵率が高い（40～50\%）地域がみられ， 虫の寿命も長い（約10年）のに, 現在その特効的な駆虫 剤は見出されていないことなど，世界的にも鞭虫はとり 残された 1 つの問題とされている。その上動物実験で も, 例えばイヌでは感染実験がうまくいかないし, 市販 マウスは一般に感受性が低い。そのためコーチゾンを投 与して感受性を高める方法が用いられているが， マウス の死亡率が高くなり, 体重の減少も著しく, 実験も煩雑 である。そこでコーチン゙ン処理をしなくても, 自然に感 受性が高いマウスの系統を探すため, ネズミ鞭虫 Tri- churis muris を, いくつかの系統を選んで感染させて みたところ，幸いに感受性が高い系統を見出すことがで きた。

生後 $5 \sim 6$ 週のマウスに, 1 頭当り 300 個の虫卵を経 口投与し，30 または 32 日後に虫体を回収し, 虫数, 虫 体和よび子宮内卵数を計測した。調査した系統のらち $\mathrm{KYF} / 2$ 系統のみ感染率が $100 \%$, マウス 1 頭当りの平均 虫数も 84 120で, これと比較のためコーチゾン $1 \mathrm{mg}$ を 4 回 $(0 ， 1 ， 7 ， 8$ 日に) 投与した GPC マウスでの虫数 にくらべて約 2 倍であった。また虫体の発育もよく, 雄 虫で平均 $14 \mathrm{~mm}$, 雌虫で $16 \mathrm{~mm}$, さらに虫の子宮内卵 数も平均 730 個を算えた。

その他の $\mathrm{C} 3 \mathrm{HeB} / \mathrm{Fe}(\mathrm{TC} 3 \mathrm{H}), \mathrm{PW}$ や $\mathrm{CBA}$ 系統は 40〜 50\%, KYG 系統は 16.7\%の感染率を示したが, い ずれも虫数が少く, 虫体の発育も悪い。また BALB/c, $70 \mathrm{C}^{\mathrm{e}}$ と $\mathrm{KYC}$ 系統では感染率 $0 \%$ であったが, 反復実 験で KYC は40\%の感染率を示した。

ネズミ鞭虫の感染虫数や虫体の発育などに関する総合 的な調查結果からみて, $\mathrm{KYF} / 2$ 系統のように感受性の 高い系統は従来の報告には見当らないし，今後この方面 の研究に有用な実験動物になるものと考える。なお, $\mathrm{KYF} / 2$ 系統の起原や, 他の特性については講演 8 で述 べる。

[発言]

安達二朗 (中外・綜合研) Trichuris muris の原記 載で本種はどの宿主より採取, 同定されておりますでし ょうか。

土川 清（遺伝研） 予研で継代されているスタムを 用いた。これは, 米国 NIH から入手したもので, house mouse (Mus m. mnsculus) から採取・同定されてい る。

\section{8. 臼歯欠如に関するマウス KY F 亜系間差異}

○土川 清, 原田和昌 (遺伝研), 土川琴代（伊豆聥信病院）

$(\mathrm{A} / \mathrm{J} \times \mathrm{CBA}) \mathrm{F}_{1}$ と $[\mathrm{DD}($ 北里 $) \times \mathrm{NC}] \mathrm{F}_{1}$ の交雑か ら得たマウスを， $\mathrm{P}$ 世代として兄妹交配をはじめ， $\mathrm{F}_{11}$ から枝わかれさせて劣性白斑の発現位置に関する無選抜 (KYF/1 系) と, 選抜 $(\mathrm{KYF} / 2, \mathrm{KYF} / 3$ 系) で 3 系統 を導いた。これらの亜系について，選抜目標にはしなか った形質,すなわち骨変異をしらべてみると，6 骨変異 と下顎第 3 日歯欠如の頻度に亜系間差異が認められ, 他 の 10 変異にはそのような 差異がみられなかった。下顎 第 3 臼歯を欠如するものの頻度は, 雌雄別に KYF/ 1 : $42.0,60.0, \mathrm{KYF} / 2: 48.0,72.0, \mathrm{KYF} / 3: 90.0,98.0$ \%で, 性別に左右側をプールして比較すると，KYF/1 と KYF/2 の雌での間を除いて, 各亜系間に差異が認め 
られた。従来特定の突然変異系のほか, 既存の近交系の らちに, KYF の各亜系にみられるような第 3 臼歯欠如 を高率に示す系統の報告はないので，それに関与する要 因や，亚系間の差異に関する遺伝要因をしらべるため, 覀系間のダイアレル交配を行ってみた。

実験が未完成の段階で，これまでに得られた結果だけ から結論めいたことを述べるのは早計であるが，各亜系 間交配で第 3 曰歯を欠如するものの頻度は一様に高くな り, 性別に左右側をプールして久如歯の頻度をみると, ほぼ用いた両親の系統のうち高い方の頻度か，またはそ れ以上に高い值を示し， $\mathrm{KYF} / 1$ と $\mathrm{KYF} / 3$ の相反交雑 でのみ明らかな母親の効果が認められた。

ここで比較に用いた数值には, 両側性欠如の頻度が極 めて大きく関係しており，KYF 亜系間での第 3 刍歯欠 如頻度の差異は, 基本的には各髙系の下顎第 3 臼歯の分 化, 発育が悪いといら 共通の 背景（遺伝子の 支配によ る）のもとで，両側性（欠如）発現を規定するか，また は歯胚退化の臨界期に関係する優性効果をもつ遺伝子の ちがいによるものと考えられる。な扣他の骨変異に関し ては別の機会に述べる。

\section{9. ベンツピレン水酸化酵素とマウスの系統差}

渡辺民朗, 菊地公男 (東北大·抗研)

〔目的〕マウスの肝, 小腸等に拈いて, 強力な発がん 剂である Benzo (a) pyrene の代謝変動について実験し た。すなわち, Benzo(a)pyrene Hydroxylase 活性の 調節機構の系統による差異が遺伝的要因によって支配さ れているかどらかについて考察した。

[方法] $\mathrm{C} 3 \mathrm{H} / \mathrm{He}, \mathrm{DBA} / 2$ 等のマウスの肝, 小腸, 肺 から Microsome 分画をとり, 基質として Benzo (a) pyrene $80 \mu$ moles を加光, Tris, MgH, TPNH, TPNH 生成系の存在下にて反応し, 生成された 3-Hydroxy-Benzo(a)pyrene を螢光により測定し, 此活性 を検べた。飼料はオリエンタル製 $\mathrm{MF}$ で, 金網底のケ ージを使用し, 自動的に 1 日のサイクルで点滅する光源 を持つコイトトロン内で飼育された。C $3 \mathrm{H} / \mathrm{He} \times \mathrm{DBA} / 2$ の $\mathrm{F}_{1}, \mathrm{~F}_{2}$ のマウスは金網のケージに移動後, 少なくと も 1 週間は飼育し, 実験に供した。

〔成績〕 1）マウス肝に批ける酵素活性を検べると系 統間に差異はなかったが，誘導物質である Methylcholanthrene を腹腔内, または経皮的に投与すると, C3H， Swiss Albino 系は活性上昇を示したが，DBA マウス は示さなかった。2）誘導物質の経口的投与した時の変 動をみると，系統間の関係は上記と同様であったが，肺 では DBA マウスで活性上昇が認められた。3） C $3 \mathrm{H}$ と DBA の $\mathrm{F}_{1}$ についてみると, 肝, 小腸ともに誘導は 明らかであった。そこで，それらの $\mathrm{F}_{2}$ を検べた。肝で
は活性上昇の陽性と侩性動物に分けられたが， $\mathrm{F}_{2}$ の雄 マウスの小腸の活性上昇は明らかに認められた。

〔考察】肝に打ける酵素誘導の系統間の差異は, $F_{1}$, $\mathrm{F}_{2}$ マウスに括いて誘導陽性マウスが優性であった。し かし， $\mathrm{F}_{2}$ マウスの小腸についてみると肝における酵素 誘導と異なることから, 肝と小腸に打ける酵素の調節機 構に異なった因子が関与していることが考えられる。

\section{0. 腸炎菌感染に対して均一高度感受性の DKI 系マウ スに, 比較的抵抗性の C3H/He 系の遺伝子を導入 した coisogenic 系統の育成実験 第 3 報}

牛場大蔵, 岸本好雄, 斉藤和久, ○前田良三 (慶大・医), 江崎孝三郎 (実中研)

〔目的〕腸炎菌感染に対して均一な高い感受性を示す 近交系の DKI マウスに, $\mathrm{C} 3 \mathrm{H} / \mathrm{He}$ から, 比較的抵抗性 支配遺伝子 $(\mathrm{R})$ を導入した coisogenic の DKI-R が 育成された。今回は育成されたマウスにつき, 導入され た遺伝子が安定して維持されること, また感染菌の宿主 内増殖抑制效果について検討することを目的とした。

[方法] $\mathrm{C} 3 \mathrm{H} / \mathrm{He}$ ○と $\mathrm{DKI}$ 果との $\mathrm{F}_{1}$ 合から DKI우 に連続戻し交配（各代の後代検定によってRを持つへテ ロのマウスを選抜）した B C 10 の動物同志の交配により $\mathrm{R}$ をホモに持つマウスを作出した。即ち交配仔のうち後 代（DKI との交配仔）が $80 \%$ 以上生残するものを，RR と判定したが，そのらち90\%以上のものを親として選抜 するよら努めた。これを $\mathrm{G}_{0}$ として, 兄妹又は colony 内交配を抗こない, $\mathrm{G}_{2}-\mathrm{G}_{7}$ マウスについて抵抗性の検定 をおこなった。また一部は後代検定をもおこなった。こ れらの検定には腸炎菌 No11 株 $10^{-6} \mathrm{mg}$ を腹腔内攻撃 し, 1 週後の生残率を求めた。また体内生菌数測定に は, No11 株 $10^{-6} \mathrm{mg}$ 腹腔内, 或いは同株の S M 耐性株 $11_{r_{6}} 10^{-4} \mathrm{mg}$ を静脈又は足踫内攻撃した後, 経時的に攻 撃部位及び脾, 肝(homogenate)の培養菌数を算定し, $\mathrm{C} 3 \mathrm{H} / \mathrm{He}$, DKI と比較した。

[成績】 $\mathrm{G}_{2}$ から $\mathrm{G}_{7}$ までの398匹中377匹 (93.8\%) が 生残し, そのうち同親の仔につい殆んどが $90 \%$ 以上生残 した。また代を重ねても抵抗性の率が減少しなかった。 DKI との戻し交配の場合にも，90\%以上が生残した。 体内生菌数については, いずれの攻撃経路の場合も, と くに攻撃 24 時間以後の肝, 脾の菌数は DKI より著明に 抑制されることが認められた。

[考察】上記成績から, 育成された DKI-R の抵抗性 が安定して維持され, 攻撃菌の臟器内増殖を抑制するこ とが確められたので，このマウスを $\mathrm{DKI}, \mathrm{C} 3 \mathrm{H} / \mathrm{He}$ と 比較して実験チフス症の自然抵抗性追究のために用いら れると考えられる。

[発言] 
今井章浩（武田薬品・生物研） 足蹠感染の意義（理 由）についてらかがいたい。

前田良三（慶大・医） マウス足踣は, 肝, 脾などに 比較してサルモネラの増殖し難い部分であり，いわゆる target organ ではないが，そのような場所でも系統間 に差があるかどらかを検討した結果, 差が認められたの で，その成績を示した。

猪 貴義（家衛試）腸炎菌に対しい高感受性系統で ある DKI 系に抵抗性遺伝子を導入した coisogenic strain が育成されたといら事実から，腸炎菌に対する 抵抗性の遺伝は single gene, あるいは major gene によって支配していると考えられる。今回の報告と関連 して, これまでネズミチフス菌に対する感受性, 抵抗性 についての遺伝支配を検討した Gowen の研究があげら れる。Gowenはネズミチフス菌に対する抵抗性は poly gene によって支配され, 複雑な遺伝型式をとることを 明らかにしている。今回の発表成績は poly gene 支配 を全面的に否定するものであるかどうか伺いたい。

前田良三（慶大・医）われわれの育成実験成績にお いても, main-gene の他に修飾的に働らく遺伝子が存 在する可能性が指摘されました。この修飾遺伝子の遺伝 型式や，抵抗性支配上の意義などについては， maingene とは又別個の問題として追求しなければならない と考えています。

\section{1. 実験感染におけるマウスの系統，週令差による菌感 受性の変動}

○五島瑳智子, 上村利明, 堂个崎勲, 桑原章吾 (東邦大・医), 西田 弮 (藤沢薬品・ 中研)

近年増加しているグラム陰性桿菌感染症の原因菌であ る大腸菌, クレブシエラ, 変形菌, 緑膿菌などは, マウ スに対しても菌力は弱く, 通常の菌株では, かなりの菌 量で攻撃しないとマウスを倒すことができない。このよ らな菌種を用いて感染防御実験を行なら場合，ぞのよう なマウスを用いるのが適当か, あるいは表わされた $\mathrm{ED}_{50}$ を比較評価するには，どのよらな基盤にもとついたらよ いかということは, 宿主と菌の組合せに加えて, 薬剤の 条件があるので，かなり複雑な問題となる。このような 問題の解析の一助として, 今回, マウスの系統, 週令に よる菌感受性の違いについて検討するため次の実験を行 なった。

〔方法〕マウスは市販の ICR, ddy, dd の 3 系統の 今。感染菌は大腸菌 C - 11 株, 緑膿菌 GNB-1-106, GNB- 2-29 を腹腔内接種, 薬剤は AB-PC, CEZ, KM をそれぞれ 1 回，皮下投与した。

〔成績〕大腸菌に対しては ICR がもっとも感受性が
高く, ddy, dd の順に鈍くなる。ICR の週令差は 4 週 令がもっとも鈍く，3，6，8では感受性が高い。これ らを治療した実験では AB-PC, CEZ での $\mathrm{ED}_{50}$ 值は $\mathrm{ICR}$ がもっとも高く, $\mathrm{KM}$ では変動がみられない。系 統差による菌感受性の違いの原因をさぐる目的で RES 機能をしらべると, carbon clearanceは dd より ICR の方が遅く，また血清成分では dd のコレステロール值 が ICR より低いことがみとめられた。緑膿菌 2 株では マウスの週令, 系統による差は明瞭ではない成績が得 られた。

[考察】 以上の実験では結論は得られないが，正常な マウスにも分布しているこれらの菌種を用いて感染実験 を行なうのには，SPF マウスなども含めた基礎的なデ 一タが必要と考える。

[発言]

猪 貴義（家衛試） I C R 系の攻撃菌に対する感受 性が 4 週令に扣いてもっとも低かったという原因につい てどのように技考えになりますか。

五島瑳智子（東邦大・医）この現象については今ま でのところまったくわかりません。先天的防衛機構の週 令差などが考えられますが，手がかりとなるよらなデー タはありません。

近藤恭司（名大・農）実験感染に拈けるマウスの系 統差をみる場合，「遺伝的体質が異なる」というデータ 一の多い系統を比較する方が，明瞭にでると思われま †。

五島瑳智子 (東邦大・医) 抗菌薬の in vivo 評価 のためには，多数のマウスを用いるので，供給面などか ら大量に入手しやすい系統で私共が日常使用しているも のについて検討した。

奥木 実（都老人研） $4 \mathrm{~W}$ 令の感受性が低く, $3 \mathrm{~W}$, 6，8Wは高いとのこと，その原因を検討するために才 ートアナライザーの測定值をさらに各週令にわたって比 較してほしい。

五島瑳智子（東邦大・医）各週令での血清オートア ナライザーの成績, 拉よび血球数などさらに検討いたし ます。

12. 糖尿病マウス 6 系統 (KK $, \mathrm{AY}, \mathrm{KK}-\mathrm{A}^{\mathrm{y}}, \mathrm{C57BL} /$ $6 \mathrm{~J}-\mathrm{AY}^{\mathrm{y}} ， \mathrm{C57BL} / 6 \mathrm{~J}-\mathrm{ob}, \mathrm{C57BL} / \mathrm{KsJ}-\mathrm{db}$ ) にお ける糖尿病症状の比較

西村正彦（和歌山医大・応医研）

〔目的〕演題の 6 系統は何れも糖尿病マウスとして認 められているが，一堂に集めての比較はなされていなか ったのでC57BLを共通の genetic background にした $\mathrm{A}^{y}, \mathrm{ob}, \mathrm{db}$ の三遺伝子間の比較，および $\mathrm{A}^{y}$ gene を KK系に導入した $\mathrm{KK}-\mathrm{A}^{y}$ 系，正常系統へ導入した $\mathrm{C} 57$ 
$\mathrm{BL} / 6 \mathrm{~J}-\mathrm{A}^{y}$ 系，carrier inbred strain である $\mathrm{AY}$ 系の 三系間の比較を行らことによって, 遺伝子差及び系統差 を明らかにした。

〔方法〕糖尿病症状として肥満の有無, 尿糖, 血糖,

GTT を指標にした。肥満の程度は生後10力月令まで每 週調べた体重により表わした。尿糖についてはテス・テ ープにより離乳後生涯まで毎週調べ冊又は卅の発症率で 示した。糖負荷試験は 5 力月令で行い, ad lib 血糖值を 調べ, 絶食後 glucose $1 \mathrm{~g} / \mathrm{kg}$ を腹腔内投与し，0，30, 60，120分後の血糖值を定量した。固型飼料は MF を用 いた。

〔成績】 雌雄とも6 系統全て肥満を起すが，その程度 は single gene の比較に打いて $\mathrm{db}>\mathrm{ob}>\mathrm{A}^{y}$ であり, $\mathrm{A}^{y}$ gene の back が変っても db, ob を越すほどの变 化は見られなかった。

尿糖発症率は single gene の比較では雄 $\mathrm{db}(83 \%)>$ ob $(28 \%)>\mathrm{A}^{y}(5 \%)$ であったが, $\mathrm{A}^{y}$ gene と background の関係では, $\mathrm{KK}-\mathrm{A} y(98 \%)>\mathrm{KK}(30 \%)>\mathrm{AY}$ $(7 \%)>\mathrm{C} 57 \mathrm{BL} / 6 \mathrm{~J}-\mathrm{A}^{y}(5 \%)$ となり, background の 影響が強くあらわれた。発症開始週令, 発症持続期間も この順位に従らが, 更に Age が進むにつれ何れの系統 も尿糖消失を来し陰性となる。性差として雌は $\mathrm{db}$ を除 き他系統の発症率が低下し, $\mathrm{db}>\mathrm{KK}-\mathrm{A}^{y}$ の順位に逆転 した。

ad lib血糖及び糖負荷後血糖は single gene として は雌雄共 $\mathrm{db}>\mathrm{ob}>\mathrm{A}^{y}$ であり, $\mathrm{A}^{y}$ gene の back を变 えた系統と比べると雄 $\mathrm{db}>\mathrm{KK}-\mathrm{A}^{y}>\mathrm{KK}>\mathrm{ob}>\mathrm{AY}>$ $\mathrm{C} 57 \mathrm{BL} / 6 \mathrm{~J}-\mathrm{A}^{y}$ の順位であった。性差として雌は $\mathrm{db}$ を 除き血糖曲線の低下が見られた。

[考察] single gene の効果の比較に C $57 \mathrm{BL} / 6 \mathrm{~J}-\mathrm{db}$ を用いる方が正確であるが，これは症状軽減して C57 BL/6J-ob に類似するといら報告があり，異った backgroundへの遺伝子導入を ob, db にも適用すれば更に 重症化することが期待できる。

\section{[発言]}

渡辺民朗（東北大・抗研） 1 . 糖尿動物の血糖值, 尿 糖值に日差変動があると思いますが, いかがでしょう か。2. 糖負荷試験の成績から尿糖值の変動の 9 系統間に 扣ける差異を説明出来るのでしょらか。

西村正彦（和歌山医大・忘医研） 1 . 日差変動は血糖 值で大きく，尿糖值で少なかった。2. 糖負荷試験による 糖処理能力に尿糖値は必ずしも比例しないので, 糖負荷 試験成績から尿糖值の系統間差異を説明出来ないと考兄 ます。

高橋和明（残留農薬研） 1 . 初歩的な質問で恐れ入り 三ますが，加令によって糖尿が消兄る原因についてどの様 に考兵て招られますか。2. 日内变動（糖尿）について本
実験はどの様に考虑されて扔られますか。

西村正彦（和歌山医大・応医研） 1. 加令による尿糖 陰性化の原因は分りません。2.1日に頻繁に採尿した 時, 日内変動は起るが, 毎週 1 度の検査では非常に持続 的でした。

前田甚作（塩野義・研） obese mouse でない普通 のマウスでもテステープで測定すると十に出ることがあ るがどらか。

西村正彦（和歌山医大・応医研） control である C57BL/6 J 系や AY 系の normal litter を詳細に調 べたが雌雄とも十を出すことは無かった。正常動物とみ なした系統でも DBA/2, KSA，AIII そ扔いては雌にの み十又は土を呈することがあり（詳細は実験動物Vol.18, No. 4, pp 147-157), 本実験では册と州を count しま した。

金武朝春（湧永薬品・中研）糖尿病の血糖值以外の臨 床症状である食量, 尿量, 飲量を測定したことがありま すか。

酉村正彦（和歌山医大・応医研）飲水量と尿量の多 いことは確認しています。食餌量は測っていませんが多 食性として知られています。

高野喜一(武田薬工・中研) マウスとラットでアロ キサン糖尿病を調べた経験からすると，血糖值には変動 があっても, テステープで冊〜冊の尿糖の出現率が 1 日 のらちに変動することはないと思う。

\section{Alloxan に対する ICR 系マウスの糖尿発症につ いて \\ 猪 貴義, ○今村憲吉 (家衛試), 伊藤雅夫 (日大・医), 角田美知枝 (日大・農獣)}

Alloxan は, 強力な糖尿発症効果を示すために, 多 くの箺験的糖尿病の研究に使用されてきている。演者ら は, これまでに, 近交系マウスを用いて Alloxan によ る実験的糖尿病の研究を行なってきたが，今回は，ク口 一ズドコロニーの ICR 系マウスを用いて, 雌雄間の発 症数, 発症率, 体重減少率等を検討し, これまでに得ら れた10近交系マウスの糖尿発症率と比較した。

材料は, クローズドコロニーの ICR 系マウスで，体 重41〜48g, 日令約100日令の雌雄を使用した。Alloxan は, 生理的食塩水に稀秎し, マウス尾静脈より注射し た。投与量は, 体重 $1 \mathrm{~kg}$ 当り, $40 \mathrm{mg}$ 区, $60 \mathrm{mg}$ 区， 80 $\mathrm{mg}$ 区, $100 \mathrm{mg}$ 区の各 4 区分とし, 各用量とも雌雄20例 を用いて行った。糖尿判定は，10日間強制排尿を行な い, 糖尿試験紙テステープの呈色反応により判定した。

発症率は, 雌雄共 $40 \mathrm{mg}$ 区では, $10 \%$ 前後の低発症, $60 \mathrm{mg}$ 区では，1日目の低発症以外は，60７0\%の中程 度の発症を示し, $80 \mathrm{mg}, 100 \mathrm{mg}$ 区では, 80 100\%の高 
発症を示した。尚, 発症率は, 雌雄間に有意差は認られ なかった。体重減少率に拈いても, 雌雄共 $40 \mathrm{mg}$ 区で は，ほとんど減少は見られず，60mg区，80mg区，100 $\mathrm{mg}$ 区と, Alloxan 投与量を増加するに従って体重が減 少する傾向が見られた。

尚これまでに得られた，10近交系マウスの糖尿発症 率と比較した場合, ICR 系マウスは, 高感受性グループ に属することが明らかにされた。

\section{[発言]}

坂口 孝（ヘキスト・ジャパン） 1. Alloxan 糖尿 の発症を尿糖陽性のみを指標とされているようですが， 他の血糖値, その他の糖代謝異常より生ずる影響につい てはいかがですか。このような他の指標での系統差はい かがですか。2. Alloxan 糖尿の場合, 投与量によっ てはその症状が次第に回復する経験を持っていますが， こような回復過程には系統差はなかったでしょらか。 3. 何か, 実験的糖永, 或いは実験動物自然発症糖尿と 臨床的な糖尿病症状とを混同した発言があった様です が，我々はこのよらな点に特に留意せねばならぬと考兄 ます。

猪 貴義（家衛試）Alloxan 注射後に扣ける糖尿発 症の回復はこの実験ではえられなかった。Alloxan は むしろ持続的糖尿発症を発現させる点で特長があるよう にみられる。しかし，これまで10系統の近交系を用いて Alloxan 飞対する感受性を検討してきたが，Alloxan の糖尿発症に対して抵抗性を示す NC 系では, 低用量区 に招いて糖尿発症を回複する結果が兄られている。Alloxan による糖尿発症の系統間差は高用量 $(100 \mathrm{mg} / \mathrm{kg})$, または，低用量 $(40 \mathrm{mg} / \mathrm{kg})$ を注射したばあいには明 らかでないが，適用量（60〜 $80 \mathrm{mg} / \mathrm{kg} ）$ を用いたばあ いに明瞭な系統間差がえられている。

今村憲吉 (家衛試) 本実験に招いては, Alloxan糖 尿の発症の陽性については, テステープを用いて判定し て抢ります。血糖值，他の糖代謝異常については検討し ていません。

猪 貴義（家衛試） Alloxan 糖尿の回復について は，これまで10系統の近交系マウスと今回報告した ICR 系について検討してきたが，実験的糖尿，実験動物での 自然発症糖尿，臨床的な糖尿病を混同することは危険で ある。しかし実験動物を用いての実験的糖尿，自然発症 糖尿の研究は終局的には臨床的糖尿病の解明をめざする のであり, 実験的糖尿, 自然発症糖尿で得られた知見が 臨床的糖尿病の病因模写, 病变模写, 疾患模写になりら るかどらか慎重に検討し適用を誤らないよらにすべきで ある。

\section{4. 市販の Wistar 系ラットより育成した近交系（W $\mathrm{T}-1)$ ，第 1 報 育成途中における基礎資料}

○高橋久英, 森 富蔵, 藤平栄一, 仲沢政雄（大正製薬）

[1]近交系名: WT-1

〔2〕兄妹交配世代数とその年次：F 20（1972年）

[3] 標識遺伝子: cc

〔4〕起源：@育成の起源となった動物：1965年12月に 森が日本ラットより日本クレア経由で購入した市販の Wistar ôㅇ 50 , 우 우 50 を, バリヤーシステムの動物 舎内で維持（温度 : $23 \pm 2{ }^{\circ} \mathrm{C}$, 湿度 : $55 \pm 5 \%$, 飼料 : オリエンタル酢母社製 NMF)。(b兄妹交配を開始した 年月：1965年12月下旬。⑳代をこえた年月：1972年 5 月。

[5]育種目標: 繁殖成績良好なもの以外は, 特別な育 種目標を定めなかった。

[6]育成者: 高橋久英, 森 富蔵, 金田 繁, 他

[7] 維持機関名: 大正製薬株式会社 $(\mathrm{J}-\mathrm{TAI})$

[8]成育途中（F 9-F 16）飞扣ける基礎資料括よび 特性：(@)基礎资料；(价産仔数（ $\overline{\mathrm{X}} \pm \mathrm{SD}) ; 8.21 \pm 3.80$, (ㅁ)離乳数; $6.70 \pm 3.80$, ( ( ) 性比; 離乳時において雄 : 倠 $=189: 193=0.939$, (二)体重； 4 週令（雄: 44.5 55.5 , 雌: 42.1土5.5), 7 週令（雄: $154.3 \pm 14.5$, 雌: 129.0 \pm 7.6 ）, 24週令（雄: 649.8 558.2 , 雌: $380.0 \pm 62.3$ ）。 (b)特性：生後 8 週令に执いて Adjuvant関節炎の発症率 を他系統と比較したところ，S.D 系（87\%～94\%)， LEW (100\%), BD-IX (33〜42\%), WT-1 ( $0 \sim 25$ \%)であった。

\section{[9] 参考文献 :}

(a) 応用薬理 (1970) 4（5）897-902

(b) 応用薬理（1971）5（2）169-183

\section{5. 核黄疸症ラットの繁殖力ならびに産仔数の滅少}

○棚瀬久雄, 鈴木善雄（三共・中央研）

〔目的〕 Albert Einstein Medical College より導 入した核黄疸症ラット (Gunn's strain) は雌の繁殖能 カがよくなっていたので, 他の系統の雌と交雑して近交 系の育成を試みているが, 黄疸症の雌 $(\mathrm{j} / \mathrm{j})$ の繁殖力は やはり低く, 産仔数も少ないのでその原因について調べ た。

〔方法】 近交10 12世代，12１4週令のものを用いて 5 つの遺伝子型の交配につき 2 週間同居させた場合の妊 娠率と産仔数を調べた。また産仔数減少の原因を調べる ために排卵数, 妊娠 6 日の着床数, 妊娠 14 日の死亡肧を 調ベた。

〔結果〕 雄の遺伝子型に関係なく $\mathrm{j} / \mathrm{j}, \quad+/+$ の妊娠率 
は $90 \%$ ，その平均産仔数は約11匹であったが $\mathrm{j} / \mathrm{j}$ の妊娠 率は $70 \%$ と低く, 産仔数も 7.0 ～7.6 匹程度と少なかっ た。また $\mathrm{j} /+,+/+$ の排卵数拈よび着床数は平均 13.5 であったが， $\mathrm{j} / \mathrm{j}$ のそれらは平均 12.5 とやや少ないよう であった。妊娠14日の死亡胚は $\mathrm{j} /+,+/+$ が平均 1.3

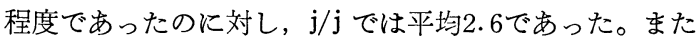
前者の死亡例が娃娠11日以前であったのに対して後者の それは12日以降の死亡例が増加していた。

〔考察】 $\mathrm{j} / \mathrm{j}$ 雌の妊娠率の低下は交尾しないことによ るものと, 交尾しても妊娠しなかったものによるもので あるが前者は性周期検査の結果，周期が不規則なことに よるものであり，後者は排卵しなかったことによるもの と思われる。このような個体では生後の黄疸症が視床下 部の損傷を引きおこし，下垂体・卵巣系の機能を低下さ せているものと推察される。また $\mathrm{j} / \mathrm{j}$ 雌の産仔数の減少 は大部分妊娠後半の肧の死亡によるものであるが，その 原因については母体のビリルビンの胎仔に対する致死作 用，胎仔と母体のビリルビン代謝の相互作用，あるいは 胎仔と母体の遺伝子型の相互作用などが考兄られるが， 胚の死亡しはじめる時期と造血器官の中心が肝臟に移行 する時期が一致しているのは興味深く，今後このような 点について検討したい。

\section{Wistar, Buffalo との比較におけるMPの行動特 性一open field における自発的行動-}

$$
\begin{aligned}
& \text { ○辻敬一郎 (名大·教羪), } \\
& \text { 鈴木善雄 (三共・中央研) }
\end{aligned}
$$

〔目的〕近交系ラットのうち, Moriyamaso(MP)： $\mathrm{F}(37+?+11)$ の個体の open field 飞拈㤝自発的行 動をとりあげ, Buffalo(BUF) : F (?+10), WistarNagoya $(\mathrm{W}-\mathrm{N}): \mathrm{F}(?+5)$ のそれと比較する。

〔方法〕被験体：各群 100 匹（雌雄同数）で, いずれ も日令平均約 90 日，15時間の給䬣制限下で観測する。行 動空間 : open field は一辺 $120 \mathrm{~cm}$ (壁面の高さ $25 \mathrm{~cm}$ ) の正方形の等質空間で，その一辺の中央に出発箱（一辺 $20 \mathrm{~cm}$ ）が付設されている。open field は観測のために 一辺 $20 \mathrm{~cm}$ の正方形に区画され，そのらち at random に決めた 2 個所に慨が置かれている。手続さ：個体を出 発箱に30秒留置した後, 入口のドアを開き 30 分間の行動 観測を扣こなう。測度には, 出発潜時, 移動区画数, 同 一区画内の停留時間なぞを採った。

〔結果〕出発潜時は, MP. W-N, BUF の順に 增大 する。一旦 open field に出た後の行動としては, MP は最初の移動活動量が大で時間とともに速やかに減衰し て非活動的な停留 (crouchingなど) に移行するのに対 し，W-N や BUF では全体としての移動量が少なく, むしろ移動を伴わない sniffing が目立ち，時間的減衰
も著しくない。反面慨への接近や攝食は $\mathrm{W}-\mathrm{N}$ が最も早 く, BUF がそれに次ぎ，MP は両者よりも時間的に遅 い。

[考察】これらの行動特徴から, MPはW-Nや BUF に比して, 新奇事態への habituation が速かであるこ とが示される。他方, 慨への到達や掑食には最も長時間 を要することから，その探索行動としての効率は必ずし も高いものとはい党ない。この点については, 今後, 各 種の条件づけの成績によっても確かめられねばならない が，同時にまた各系統間にみられた生育過程における差 異（群内個体間の攻撃の頻度差など）之関連づけて検討 することも必要と思われる。

\section{[発言]}

奥木 実（都老人研） 行動実験の場合, くりかえし 実験の影響はいかがですか。馴れ，トレーニングはあり ませんか。

辻敬一郎（名大・教養）この実験では新奇事態での 自発的反応の特性をみることが主眼であったから，同一 個体についての反復測定は避けた。しかし，反復による habituation はむろん生ずると思われるし，またその habituationの過程に種差や系統差もあり，それ自体興 味ある問題だと思う。ただ，同一事態での反復測定によ ると habituation と同一事態での測定の持続にともな らそれとはきわめて類似したパターンを示すことが別の 実験で確かめられている。

野田安孝（久留米大・医） Urination p defecation の後の実験法について御教示下さい（一匹の Rat の観 察後，次の Ratをopen-field に入れる時，どのように されているか?)。

过敬一郎（名大・教養）この種の測定に抢いて, olfactory cue の効果は大きいと思われるので，各個 体の行動観測の終了ごとに open-field 内部を洗浄して いる。データには，個体の観測順序による一定の偏りは 検出されなかったので，一応その種の cue の統制はお こなわれたとみなしてよからう。

\section{7. 市販 Hartley-F モルモットにおける移植免疫反応}

○高橋 宏, 三浦 馨, 橋本達一郎, 室橋豊穂（予研・結核部），依田八 治 (予研・獣疫部)

現在，一般に広く使用されておりますモルモットは， 1954 年米軍 406 部隊綜合研究所より 予研に 分与された Hartley 系モルモットを基にするもので， random breeding の非常に利用価値の高い品種であります。一 方，分与をらけた時以来共同研究者依田は，これを基に して inbreedingを执こない24代を継代した。そこで私 達は, skin graft により組織適合性をしらべたところ， 
この動物を Hartley No. 25 と仮称しておりますが, 近交化されていることを確認して打ります。表題の“市 販 Hartley-F” は20代 inbreeding された時点で船橋 農場に分与されたもので, 分与されてからは random breeding され市販されているモルモットであります。 この近交化されたモルモット（Fモルと略す）と通常の out bredの Hartley（Hモルと略す）がまざった状況 で供給されることは, 種々の点で混乱が生ずることは当 然であります。そこでこの F モルを皮唐, 脾細胞, 骨髄 細胞の移植免疫反応から組織適合性が高いこと, $\mathrm{H}$ モル と区別されるべきであることを確認したのでその成績を 報告します。

皮膚移植では, $\mathrm{H}$ モルの移植 7 日には生理的色調を呈 して生着していますが, 13日には黒褐色に変色して脱落 します。それに対してF モルは, 移植後 $3 \sim 4$ 週に発毛 し200日以上も密生した長毛の有毛 graft として生着し ています。ついで, 結核菌感作動物の肉芽腫脾細胞を正常 recipient モルに細胞数 $3.8 \times 10^{8}$ の移植を行いました。 ッ・アレルギー受身伝達を indicator にして, 細胞移 入直後と 1 週後に PPD $40 \mathrm{mcg}$ を皮内注射してッ・ア レルギーの受身感作をしらべました結果, Homograft rejetion がおきない時点の 細胞移入直後では両群とも 強いツ反応を呈しているが，1 週後にはFモルのみに強 いツ・アレルギーの持続が認められて, 移入細胞に対す る rejectionがなかったことを示していました。さらに 骨髄細胞移植の実験では，2 週間以内に $100 \%$ 致死せし めることのできる ${ }^{60} \mathrm{C}$ の全身照射を行い，照射㨁後に正 常モルの骨髄細胞の移植を行ったところ, 細胞移入が $1 \times 10^{7}$ 以下の場合にはいずれの組合せでも救命効果が なく死亡しますが， $5 \times 10^{7}$ 以上の細胞移入であれば， F

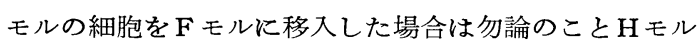
の細胞をHモルに移入しても 100 日以上の生存が認めら れています。これは, skin graft の場合と異なります が, recipient の動物が致死量の放射線を全身照射をう けていることと，現在の Hartley か closed breeding のため比較的 Histocompatibility が高まっているため

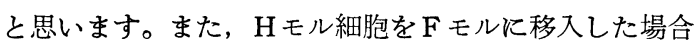
には救命効果がなく死亡しますが， $\mathrm{F}$ モル細胞を $\mathrm{H}$ モル に移入した場合には生存して括ります。これは，Recipient のFモルには, $\mathrm{H} モ ル の 1$ 部の組織抗原しかない ために rejection がおこり, Fモルの origin が Hartley であることを裏付けています。

以上, 皮䖉, 脾細胞, 骨髅細胞移植の 3 つの実験から 市販 Hartley-F は組織適合性が高い近交系モルモット であり，out bred の Hartley と区別して使用すべき であることを報告します。

[発言]
江角吉造（日本シエーリング） Hartley と船橋の 2 系統のモルモットに放射線をあて，骨髄細胞を移植した 場合, 一定以上の量を入れる事が生存に必要である。し かし両系統には共通の組織適合因子の他にプラスアルフ アの因子をもったものが一方にあって，その系の骨髄細 胞を他方に入れた場合は充分な量を移植しても，Graftversus-Host 反応により生存し得ない，と理解したがそ れでよいか。

高橋 宏（予研・結核部）さきほど述べましたよう に, Hartley モルモットの細胞をFunabashi モルモッ トに移入した場合には救命勃果がなく死亡しますが， Funabashi モルモットの細胞を Hartley に移入した 場合にの及生存が認められています。これは，Funabashi モルモットを recipient にした場合に移入される Hartley モルモットの細胞との間に共通抗源が 1 部しか ないために rejection が起り, 2 週間以内に死亡してお りますので, 先生の理解されたので結構です。

$$
\text { ノーマル・データー }
$$

\section{8. ウィスター今道系ラットの胎生期およひ哺乳期の成 長に関する研究 (I ) 体重およひ臓器重量}

○塩田尚三, 杉山 修（中外・綜合研）

〔目的〕胎生期, 乳仔期の成長には多くの要因が関与 するウィスター今道ラットについて現施設環境下, 一定 条件下での胎生哺乳両期間中の発育の標準的な資料を得 ることを目的とした。

〔方法】胎令 13 日以後の胎仔体重および conceptus の重量推移, 乳仔体重, 主要臟器重量推移を哺乳期隔日

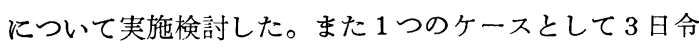
より24時間強制離乳後再哺乳させた乳仔重量についても 検討した。

〔成績〕（1）胎仔, 胎胞重量は胎令 15 日以後急激で平 行的な増加がみられ, 胎液は18日でピークを示し以後粘 稠性増加と共に減少，（2）相対的には胎仔体量増加にほ ぼ反比例して胎液が減少, (3) 乳仔体重臟器重量および 長さの増加推移を直線で示した場合, 各藏器に特徵ある 傾向がみられた。即ち 1 相性 (脾) 2 相性（体重, 体長, 尾長, 子宮, 胸腺(合)), 3 相性 (肝, 堅, 副腎, 胸腺, 殬丸, 卵巣, 消化管（内容物, 膵腸間膜を含む）腸管長） に分けられ, 直線勾配の変る時期は $5 \sim 7,9 \sim 11,13$ 〜15日であった。（4）０日令重量や長さに対する増加倍 数は21日令で睪丸が最も大きく38.5倍であり，20１0倍 は脾, 胸腺, 消化管, 子宮, 腎の順で, 10倍以下は体重, 肝, 副腎, 尾長腸管長, 体長であった。（5）比体重值で は肝, 副腎は 3 日令まで激減以後体重と平行増加, 15日 以後再び急増, 腎は 3 日まで上昇以後15日まで体重と平 
行, 17日より急増, 脾は 3 日令まで急増後体重と平行, 睪丸は11日以降特に15日令より著明な増加，（6）完全絶 食後再哺乳仔の重量回復は 7 日令まで体重はみられなか ったが, 肝, 腎, 心, 副腎は 1 日目（5日令）で重量増 加回復傾向著明であったが脾, 胸腺, 䁄丸, 尾長では 6 日令まで絶食の影響がより強く波及した。7日令では各 々著明な回復徵候がみられた。

〔考察】胎乳仔重量推移は著明で特徴があり乳仔造血 機能, リンパ球上昇時期, 肝機能などと考兄合せると興 味深い。また動物種によって乳仔臓器重量推移が異なる ものがある。

\section{9. ウィスター今道系ラットの胎生期および哺乳期の成 長に関する研究 (II) 化骨核の出現時期と化骨化の推 移}

○杉山 修, 塩田尚三（中外・綜合研）

〔目的〕前報告と同様にウィスター今道ラットの胎生 哺乳両期間中の骨格発育の標準的資料を得ることを目的 とした。

〔方法〕胎令13日以後の胎仔および 0 日令，1日令以 後隔日令乳仔の骨格観察をアリザニンレッド S 骨染色後 行ない, 化骨核の出現時期, 長骨計測による化骨過程推 移について検討した，また 3 日令より 24 時間完全絶食後 再哺乳した乳仔化骨過程推移への影響についても検討し た。

〔成績〕（1）化骨核の出現は胎令 15.5 日に鎖骨，下顎 骨にみられ，上下肢骨では16.5日以後に出現し，上肢骨 の方がより早く進行した。（2）椎骨の椎弓は17.5日から 頸腰椎上部に観察され, それ以後は尾側方へ進行し全椎 弓がみられたのは生後 3 日令であった。一方椎体は18.5 日に胸椎中央部から腰椎上部にわたってみられ, 以後頭 側, 尾側方に進行するが 尾側方への進行がより早かっ た。尾骨は7 日令まで急速に順次出現するがそれ以後は 緩慢であった。頸椎体のうち第 2 椎体の出現がもっとも 遅く，3日令で全頸椎体がみられた。（3）四肢長骨の化 骨化は胎令および日令が増すに従って，その長さに拉い て直線的な増長が認められたが，胎生期では上肢骨の化 骨過程が若干早く哺乳期になると下肢骨の方がより急速 であった。（4） 3 日令乳仔の 24 時間強制離乳による化骨 過程に対する影響は完全絶食期間中にも化骨化は進行し て扣り,むしろ再哺乳 2 日目の 6 日令で, 哺乳仔に対す る差がもっとも大きかった，しかしながら７日令では回 復の傾向が著明であった。

〔考察〕 ラットの化骨核出現時期扣よび化骨過程のバ ラッキは少なく, これらの検討から妊娠後期の胎仔毒 性, あるいは栄養障害, 乳仔を対象とした実験での発育 度を問題とする場合，また死胎仔の死亡時期の推定など
に利用できるものと考觉る。

\section{0. 高齢（生後 $\mathbf{2}$ 年以上）Wistar-Imamichi Rat の 解剖所見ならびに臟器重量について}

上松嘉男, 若藤靖匡, 川西宏明, 藤田博文, 古沢優子, 斎藤キミ子, 毛利弘子, 筏井 洋, 田内清憲, 鈴木勝士, ○五十嵐章之, 須藤㻟雄

(動繁研)

Conventional な条件下に拈いて，配合粒餌によって 1 年間 (10例) および 2 年 (17例) 以上生存したWistarImamichi 雄ラットの剖見所見ならびに藏器重量につい て比較検討した。

外望は, 1 年令では被毛光沢, 皮フの色, 执よび栄養 状態良好であったのに比べ, 2 年令では被毛の光沢消失, 剛毛で疎になり，皮フに色素沈着がみられ皮下脂肪も少 なく削瘦し動作はにぶく食欲のみ旺盛で，交尾欲が消失 するなど高令に特徵的な様相がみられた。

臓器の異常と疾病の発生率については, 2 年令で下垂 体腫瘍 33\%, 生殖器系の異常（主として萎縮） $22 \%$, 腎 臓の貧血性梗塞 $28 \%$, 化膿性疾患（鼓室の化膿）扣よび 肺炎 $44 \% ， 5$ 粜94\%（1 年令では 60\%）がみられた。

体重では, 1 年令に比べ 2 年令で減少が認められ, 最 も軽いもので $251.0 \mathrm{~g}$ であった。

解剖した臓器は, 脳, 外涙腺, 耳下腺, 顎下腺, 舌下 腺, 肺, 脾, 心, 食道 (重量-長さ), 胃, 小腸（重量· 長さ), 大腸 (重量 - 長さ), 肝, 膵, 松果体, 下垂体, 甲状腺, 副腎, 胸腺, 包皮腺, 膀胱, 尿道球腺, 精巣, 精巣上体, 輸精管, 精囊, 凝固腺, 前立腺(背葉·腹葉), 輸精管腺, 陰茎, 腎および肛門挙筋の重量を測定した。

上記の測定した臟器重量の中で 1 年令と比較して差の 認められたものについてのみのべる。2 年令で下垂体, 副腎重量が重く, 肚門挙筋の重量は著しく軽くなってい た。2 年令で,下垂体腫瘍が 5 例認められ重量は396.0 $39.0 \mathrm{mg}$ の幅があった。下垂体腫瘍があるラットのらち 精巣重量が著しく軽いものと, 1 年令の精巣重量と変わ らないものと 2 種類の型が認められた。また, 精巣の萎 縮している個体で，下垂体腫瘍の有無にかかわらず精巣 重量が 1 年令と変わらなかったものでは, 副生殖器重量 はかえって重かった。

[発言]

高橋和明 (残留農薬研) 本ラットは何年位生存しま すか。私は NCS 系マウマについて観察した際, 加令に ともなって腓腹筋の重量減小を認めて扣りますが，もし 先生の方で検討されていましたらおしえて下さい。

五十颳章之 (動繁研) 腓腹筋の重量は測定して括り ません。 
前田甚作（塭野義・研） 自然発生癌は無かった?。 前者の質問に和答えすることになるが，Wistar Rat の lifespan 測定をしたのであるが，その経験では，自然 発生癌が20力月以上になると約 $50 \%$ 程度発生した。勿論 これは系統の特徴でもあると思う。寿命の最長は 1,100 日，50\%死亡日令が860日であった。

降矢 況 (国立衛試) 1. 外部腫瘤の発生率は?。

2. 膀胱結石の発生率（国立衛試では Wistar 系ラッ トで 1 年目で死亡率は $20 \% ， 2$ 年目で35 40\%であり，

一般に雄より雌の方が低くなる）?。

五十風章之 (動繁研) 1.2 年以上生存したラット で17例中 2 例に乳癌が見られました。2. 今回の動物に は膀胱結石は認められませんでした。

\section{1. 高齢（生後 2 年以上）Wistar-Imamichi Rat の} 血液生化学的検查ならびに血液生化学的検討

土松嘉男, 若藤靖匡, 川西宏明, 藤田博文, 古沢優子, 斎藤キミ子, 毛利弘子, 筏井 洋, 田内清憲，○鈴木勝士，五十風章之，酷藤环雄 (動繁研)

Conventional な条件下で配合粒慨で 飼育した雄の Wistar-Imamichi 系ラットの 2 年以上の生存例18例, 1 年令 10 例, 離乳後, 船橋農場製の固型飼料で飼育した 6 力月令15例扣よび 3 力月令例10２7例の動物について 後大静脈血を用いて, 赤血球数 ( $\mathrm{RBC})$, ヘマトクリッ 卜值 $(\mathrm{Ht})$, ヘモグロビン量 $(\mathrm{Hb})$, 白血球数 ( $\mathrm{WBC}$ ), ならびに血漿中の総蛋白量 (TP), 尿素窒素量 (UN), 総コレステロール量 $(\mathrm{TCh})$, アルカリフォスファター セ活性值 (ALP), トランスアミナーゼ活性值 (GOT, $\mathrm{GPT}$ ), 血漿, 脳, 赤血球中のアセチルコリンエステラ 一ゼ活性值 (CHE) を測定し比較した。

血液検查に関しては，テクニコン社製の SMA-4 A型 自動分析装置を用い，TCh 抽よび CHE を除いた血液 生化学的検査に関しては日立製作所製の $\mathrm{H}-400$ 型自動 分析装置を用いた。又, $\mathrm{TCh}$ は Zak-北村法， $\mathrm{CHE}$ は Michael一上田法により測定した。

加令により著明な变化を示す検査項目は ALP 以外に なかったが，ほとんどの検查項自で，1年令までは変動 が小さいのに 2 年令では大きくなる現象が認められた。

2 年令に拈ける 各検査項目の 平均値と標準偏差は, $\mathrm{RBC} ; 788 \pm 178 \times 10^{4} / \mathrm{mm}^{3}, \mathrm{Ht} ; 52.3 \pm 7.4 \%, \mathrm{Hb}$; $15.99 \pm 2.33 \mathrm{~g} / \mathrm{dl}, \quad W B C ; 7930 \pm 3680 / \mathrm{mm}^{3}, \quad$ TP ; $7.00 \pm 0.64 \mathrm{~g} / \mathrm{dl}, \mathrm{UN} ; 14.2 \pm 3.7 \mathrm{mg} / \mathrm{dl}, \mathrm{TCh} ; 127$ $\pm 56 \mathrm{mg} / \mathrm{dl}$, ALP ; $21.23 \pm 6.88 \mathrm{~K}$. A. 単位, GOT ; $87.8 \pm 24.4 \mathrm{~K}$ 単位, GPT; $78.5 \pm 24.4 \mathrm{~K}$ 単位, $\mathrm{CHE}$

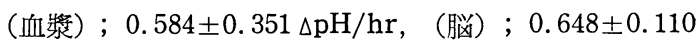

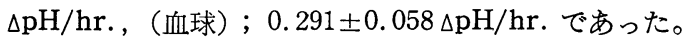

392mg の下垂体腫瘍のあった個体では RBC ; 350× $10^{4} / \mathrm{mm}^{3}$, Ht ; $27 \%$, Hb ; $8.2 \mathrm{~g} / \mathrm{dl}$, T.P. ; $5.4 \mathrm{~g} / \mathrm{dl}$ の極端に低い值を示し，64mg の下垂体腫瘍のあった個 体では（副腎 $114 \mathrm{mg}$ ，腎 $5.05 \mathrm{~g}$ ，肝；25.91 g)，TCh $315 \mathrm{mg} / \mathrm{dl}$, CHE (血漿) $1,858 \Delta \mathrm{ph} / \mathrm{hr}$ ．の高い值を示 した。

又, GPT では, 1 年令, 2 年令で, 150 単位以上の高 い值を示す個体が増える傾向が認められた。

\section{[発言]}

坂口 孝(ヘキスト・ジャパン) このような血液学 的性状, 生理值は採血方法によっても異なると思います が，先生はどのような採血方法を扮使いになりました か。

鈴木勝士（動繁研） 血液学的検査に関して，採血部 位による相違は確かにあります $(\mathrm{RBC}, \mathrm{Ht}, \mathrm{Hb}$ にお いては，採血部位による相違は比較的小さいが，WBC に拈いては著しい)。今回の成績は，全て後大静脈より 採血した血液によって得られたものです。

橋本秀介（ヤクルト研） アルカリホスファターゼの 加令による減少の原因について，どら考えられるか。遊 離とエステル型のコレステロールの定量を行っておられ るか。

鈴木勝士（動繁研） ALP についてその活性値を変 動させる原因については, 臨床的にいろいろ言われて特 りますが，今回の加令にともなら活性値の減少は，骨の 状態 (Ca 代謝の加令による変化) を反映しているので はないかと考光ております。コレステロールについて は，Zak-北村法による総コレステロールの定量の及行 ない，遊離型およびエステル型コレステロールの定量に ついては行なって扣りません。

\section{2. ラットの老化に関する研究 I . 死亡率, 臟器肉眼 所見およひ臟器重量について}

○飯塚 壮, 渡辺満利, 小堀ナホ, 田中寿子 (実中研)

〔目的〕ラットを用いた長期実験では, 加令に伴う疾 患の発生を頻々経験する。今回次の二目的をるってS. DJCL， Donryu-JCL の老化に伴う諸变化を検索した。 1. 一般毒性試駼に S. D-JCL を用いる場合の基礎デー ターを得ること。2. S.P.F 化された他系統ラットを, 同一条件下で飼育し, 長期毒性試験にどの系統が最も問 題が少いかを検討すること。

〔方法】 S. D-JCL, Donryu-JCL 雌雄計 475匹を, 1 ケージ内 5 匹とし, 恒温, 恒湿の環境下で飼育, 固型 飼料 CA-1, 扣よび水道水を自由摄取させ, 週 1 回各 個体の観察を行った。9，12，15，18，打よび24力月令 に 1 群雌雄各20匹につき, 血液学的検査, 血清生化学激 
査, 尿検査, 剖検, 臟器重量の測定, 組織学的検查を行 なった。これらの諸検査の内, 今回は, 死亡率, 剖検時 の肉眼所見, 臟器重量について報告した。

〔結果】両系統とも雄に早く死亡がみられ, 死亡率 は, S. D 雄にもっとも高い結果を得た。死亡動物の臟器 変化は, S. D 雄では腎症発生率が50\%ともっとも高く, 両系統の雌では乳腺に起因すると考兄られる皮下腫瘤が 40\%と高率で, Donryu では雌雄ともに肺感染症の発生 が高率であった。剖検時の最終体重は雌雄ともに S.D で大きく，Donryu との間に著しい差が認められた。 脳, 心臟, 鋅丸, 子宮重量に関しては, 加令, 系統差, 体重による差はほとんどなく，一定の重量を示した。他 方, 肝, 腎臟重量は両系統間に差がみられたが，これを臓 器体重比で示すと，両系統ともほぼ近い值を示した。剖 検所見では, 表面顆粒状で, 褐色調の強い腫大した腎症 の変化が, S. D 雄に $28 \%$ と最も多く見られ, 加令伴い 発生率が増加した。腎結石は, Donryu雄 $12 \%$, 雌 $2 \%$ のみに見られ，肺感染症もDonryu に高率であった。皮 下腫瘤は両系統の雌に多く, S.D の方が高率であり，発 生率は加令に伴い増加を示した。発生部位は下腹部から 鼠経部にかけて最も多く, 大きさは手挙大に至り, 多く は単発で周囲組織との癒着も比較的軽度であった。卵巣 Cyst 形成が，Donryu 24力月令に高率で，またDonryu 雄に扔いては, 白内障が $22 \%$ そられた。

〔考察〕S.D-JCLに高率に認められた腎症発生率を， Berg の 報告 ${ }^{1}$ とみられるS. D 腎症発生率と比較すると， 著しい差異は認められず, 高率な腎症発生は, S. D-JCL に特異的であるとするより，S.D系統に高率と考光られ た。他方 Wistar King A ラットつ慢性腎炎に関する 報告2)では，きわめて高率であり， S.D 系統のみに特に 高率とは考㝋にくいようであった。24力月令雌 S.D に

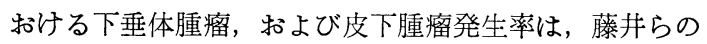
報告 ${ }^{3)}$ と近い值を示し，そつ発生率は Donryu 雌と比 し, 両系統間に著しい差異はみられなかった。しかし白 井らの Wistar King A 飞関する報告では ${ }^{4)}$, 雌50例中 5 例に下垂体腺腫がみられて居り, 我々の結果とは著し い差異が認められた。

1) Cotchin, E. \& Roe, F. J. C. Pathology of Laboratory Rats and Mice. p. 749, Blackwell Scientific Pab, Oxford and Edinburg, 1967

2）日井敏仁他：日病誌，58，202，1968

3）藤井登志之他：第 61 回日本病理学会総会, 東京 1972

4）臼井敏仁他：日病誌，53，123，1964

\section{[発言]}

梶原 疆（武田・生物研）「老化」が割に不用意に
使われていますが，長期飼育という言葉を使わないと， いろいろ混乱を起すと思いますがいかがでしょうか。体 験によりますと, ラットの 1 年或は 1 年半以上は, 仮に 感染を除きましても個体差が甚だしく，臨床的研究とま で云わなくても，個体別の記録が必要であり，また病理 所見も人体の剖検例のように1例ずつを吟味する必要性 を感じました。血液学的一生化学的 Data の統計をとる ときによく注意せねばなりません。

奥木 実（都老人研） 梶原先生が㨟っしゃる通り， 老化とか加令をいらことばを使うことは多くの問題があ り，簡単には云光ないと思います。老化とは何か，いつ からを云いどのよらな状態を老化と云らか，大へん難し い問題です。今迄やられた老化の実験もそれ以外の多く の要因が関与しているし，それをどれだけ除去して実験 されたか今後充分検討していただきたいと存じます。

飯塚 壮 (実中研) 無解答。

\section{Sprague-Dawley-JCL 系ラットの長期飼育のー 経験}

○西部忠幸, 橋本喜信（日本曾達，生科研）, 螺良義彦（奈良医大）

長期毒性試験に用いる動物は, 実験に当ってはその動 物の持つ特性を充分に認識していなければならない。 演者らは，わが国に拈いて毒性実験に繁用されている Sprague-Dawley-JCL ラットを長期間飼育し，種々の 知見を得たので当研究所の飼育条件下での結果として報 告したい。

〔方法〕以下にのべる結果は，いずれも1967 年から 1972年までの 5 年間に得られたもので，ラットは日本ク レア(株)より 4 週令で購入し, 当研究所の環境に 1 週間 馴化させた後に毒性実験の対照として，正常に飼育した 318匹（合 159，ㅇ 159）の分をまとめたものである。飼 育条件は, 室温 $22.0 \pm 0.5^{\circ} \mathrm{C}$, 比湿度 $55 \pm 5 \%$, 換気 $12 / \mathrm{hr}$, 照灯時間は午前 9 時から午後 5 時 ( 8 時間)。う ットは，ステンレススチール製アミケージに同性のもの を 2 匹ずつ入れ，飲水及び提䬣は任意に行わせた。又尚 各種機能検査の前に絶食はしなかった。

〔結果〕 2 年間に死亡したラットは, 肺, 腎, 下垂体, 乳腺などに，炎症又は腫瘍の発生をみた。即ち，気管支 肺炎を主とする肺炎 $34.3 \%$ 糸球体腎炎が $53.1 \%$ と高 く, 下垂体及び乳腺の腫瘍はいずれも $24.2 \%$ 発生であ った。尚乳腺腫瘍発生については性差がみられた(っ7.8 $\%$, $40.0 \%) 。 一$ 方各種の機能検査の結果，加令にと もなってその測定值が一定の变化を示す事が分った。即 ち加令にともなって上昇するものとして, 総コレステロ ール, S-GOT, S-GPT 等, 又下降するものとして, ALP, PBI，赤血球等であった。又加令により变化しな 
いものとして, 総蛋白量, アルブミン, BUN, 及び血 糖等であった。

更に, 臟器重量についても, 加令にともなって変化す るものがみられ, 減少 (又は消失) するものは胸腺で, 逆に下垂体では増大する傾向がみられた。

〔結語】今回, 瑇性実験に用いた対照群を，2 年間に 亘って整理した結果, いわゆる normal data といわ れ, 吾々が参考にして来たものが, 加令とともに色々の 方向に変化する事を知った。従って長期実験に当って は, その環境下に打ける, 加令による変化を充分知る必 要があろう。

24. Sprague-Dawley JCL ラットの加令にともなう 諸変化 I．体重および生理値

○小林孝好, 笠井一弘, 梁川嘉子, 坂口 孝 (ヘキスト・ジャパン)

我々は, Barrier System と Conventional な動物 飼育施設において SD-JCL ラットを，長期に飼育し， 加令がラットにどのような影響を及ぼすかを検討した。 その結果, 生存動物数は, 13 力月以後に急减し, 今の 方に早く死亡するものが多い。又体重は 3 力月迄は急速 に増加し, 以後は 1 年半迄, 徐々に増加した。

ラットに持ける加令の 影響と性差は, 一部の 生理值 (ALP, $\mathrm{Na}^{+}, \mathrm{K}^{+}$, 総 Cholesterol, 総蛋白), 臟器重 量（腎，甲状腺，下垂体，副腎）に見られ，それらの変 化は13力月以後に顕著となった。特に，令では腎炎を伴 う腎重量の 増加と上皮小体を含む甲状腺の増大が見ら れ, 早では副腎の増大が見られた。又13力月以後に乳腺 の腫瘍が高率に見られた。これらの変化は, Conventional な条件で飼育したものについても同様であった。 従って, これらの変化は, SD-JCL ラットの特徵といえ る。

又ラットを長期に飼育する場合，我々の様な飼育方法 をとった時には，1 年以上飼育するものについては, ·自 然発症的に, 病的変化の現われる可能性が増光ること を，念頭に执かなくてはならない。そして，その原因が 常に個体の加令, 臟器自身の加令からくるものか, それ に感染や栄養等の外的要因が加わっているのかは, 今後 検討しなければならない。更に，今回の実験成績から， もし質の良い動物を用いるならば, Conventional な飼 育方法でも，その管理方法によっては， Barrier System とさほどその加令の変化に差のみられない動物を, 飼育できるということを知った。しかしこのことは長期 実験に打いて，複雑な Barrier System の飼育方法ま で行なわなくても良いということではなく，むしろ長期 に実験動物を飼育する場合には，Barrier Systemが外 部からの感染を強く防禦することは，みのがせないとこ
ろである。

\section{[発言]}

中尾寿夫（日本シェーリング） SD-JCL ラットを約 2 年間恒温恒湿下に飼育した結果, 体重については生長 期に体重増加が多いのは当然であるが，その後もわずか であるが増加を示す。特に雌では高令となってからもか なりの増加をみる。未梢血所見では 8 週令以降各血球数 がほぼ一定となるが， 1 年以降赤血球, へモグロビン, リンパ球の減少が認められる。血液生化学的検査で, 15 項目程行った中, 尿素窒素は老令となると増加, 成熟動 物のアルカリホスファターゼは幼若のものの半分以下を 示す。コレステロールは 6 力月令頃から次第に增加,

$\mathrm{A} \cdot \mathrm{G}$ 比, 総蛋白は高令になると減少がみられる。藏器 の相対重量については，一般に成長期は次第に減少し, 成熟後ほぼ一定となるが，高令では再び減少を示してい る。

笠井一弘（ヘキスト・ジャパン）我々の場合は, 赤 血球の減少は認められて抢らず, $\mathrm{Hb}$ は減少というょり は一定になる傾向がみられた。リンパ球の減少は好中球 の増多による二次的なものといえる。総蛋白は, 高令に なるとやや減少の傾向にあるが， 6 力月以降あまり変化 はみられない。又 $\mathrm{A} / \mathrm{G}$ にも変化はみられない。臓器体 重比では，一般に加令とともにその比が 減少している が，腎藏，下垂体，甲状腺など藏器自体に変化の現れる ものでは, その比は再び増加している場合もある。

ある点では我々のデータと同様な点もあり, 又異って いる点も認められるが, しかしこのよらな臟器重量, 生 理値などは, 飼育管理方法, 飼料, 感染等の外部環境要 因による影響を受けやすいので，一般的に SD-JCLラッ トの生理值を断定することは出来ない。したがって，こ のような生理值の検討には, 十分慎重な配慮がなされる ベきである。

\section{Sprague-Dawley JCL ラットの加令にともなう 諸変化 II. 病理組織学的変化}

○笠井一弘, 重栖幹夫, 小峰作次, 坂口 孝 (ヘキスト・ジャパン)

〔目的〕 ラットを長期間の動物実験に使用する場合, 加令にともなって現われてくる種々の自然発症の変化を 知ることは, その実験結果を正しく評価する為に重要な ことであると考光, 各週令のラットの病理学的変化につ いて検討した。

〔方法】使用した動物および, 飼育条件は前報と同じ である。屠殺した動物についてはただちに各缄器を取り 出し, 肉眼所見を観察後, $10 \%$ ホルマリン液にて固定, 型のごとく組織標本 (H-E 染色) を作製鏡検した。

〔成績〕水腎症は早期より現われるが，週令による差 
はない。系球体炎, 腎孟腎炎の像を示す細顆粒状の腎变 化は雄で 7 力月頃より現われ，13力月以降で死亡する大 多数にみられ, 雌では雄に比して軽度であり, また, や や遅く出現する。

胃潰瘍, 悪性リンパ腫, 膵島腫, 皮フの乳頭腫, 卵巣 の腫瘍等はいずれも単発的である。

肝の腫瘍は19力月以降の雄に多くみられた。乳腺の腫 瘍は雌ラットで13力月以降に出現し, 死亡例の大多数に みられる。その他, 下垂体, 甲状腺の腫瘍及び, 副腎の 結節性肥大は13力月以降の雌雄いずれにもみられた。

[考察〕 1. SD-JCL ラットの主要死因は雄では腎变 化であり, 雌では乳腺腫によるものが多い。

2. 13力月以前にも水腎症や, 悪性リンバ腫などがみ られるが，13力月以降飞 種々の 変化が多く現われ始め る。

3. 病理組織学的にも今後, 加令の影響の検討に際し て飼育条件, 飼料, 感染など外的要因の影響を考慮して の検討が必要である。

4. 以上のごとく, 本ラットを長期間の実験に使用す る時, 特に, 13力月以降では種々の变化が合併, 死亡率 も增すので実験結果の 考察には充分な 注意が 必要であ る。

\section{Chinchilla の繁殖について}

○遠藤 克, 西川演八 (日大・医), 相馬広明 （東京医大），佐久間勇次（日大・農）

〔目的〕 前回の大会で, 実験動物としての Chinchilla を紹介したが, その後, 順調に繁殖しているので, 繁殖 方法, 繁殖季節, 産仔数括よび性比等についてその成績 を報告する。

〔方法】現在, Chinchilla の繁殖は4つの方法 (1. つがい式，2.一夫多妻式，3. 一夫多妻コロニ一式，4.禁 猟区式）によって行なわれているが，Chinchilla の雌 が非常に闘争性を持つことから，比較的一夫多妻式が多 く取り入れられて和り，私共もこの方法によって行なっ た。この方法は，1匹の雄に対して 4 〜 5 匹の雌をそれ ぞれ個室に入れ，各個室から出られないようにする一 方，雄の方は自由に雌の各個室に出入できるようにした ものである。

[結果〕 Chinchilla の繁殖季節は11月から翌年の 5 月までの間であり，分婏時期はその後，平均妊娠日数 111日を加えた 2 月から 8 月に起る。これまでの 81 例の 分婏例をみると，この間に分婏したものが63例 $(77.8 \%)$

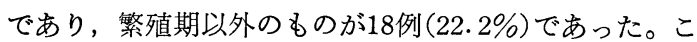
れらの産仔数をみると 1 仔から 4 仔分婏するものが認め られ，その内訳は，1 仔のものが22例(27.2\%)，2 仔の ものが 41 例(50.6\%)，3仔のものが17例(21.0\%)，4 仔
のものが 1 例 $(1.2 \%)$ であった。 81 例の分婏例から得ら れた産仔159匹の性比をみると, 雄が 104 匹 (65.4\%) に 対して雌が55匹(34.6\%)であり, 雄の方が有意に多かっ た。

〔考察〕以上の上うに, Chinchilla は繁殖季節内に 妊娠するものが約 $80 \%$ あ゙あり，それ以外のものは $20 \%$ 位 認められた。産仔数は，2 仔を分婏するものが全体の半 分を占め, ついで 1 仔, 3 仔の順であった。性比は, 有 意に雄が多い結果が得られたが，これは，雄のみを分婏 したものが 36/81 (44.4\%) と多く，この結果によるもの と考えられる。

\section{[発言]}

北德（家衛試） チンチラの場合，後分婏排卵時 に受胎するものがあるよらですが，今回のデーターにお いてどの程度認められましたでしょらか。

遠藤 克（日大・医） Chinchilla では，分娭後30 〜38時間後に排卵が認められ，分娩後すぐ受胎するもの がある。今回のデーターで分婏後 6 力月以内に次の分婏 が認められたものは $20 / 81$ 例(約 $25 \%$ )，4 力月以内のもの は11/81例(約14\%)であった。

田嶋嘉雄（日獣畜大）排尿の量，ならびに，に抒い について伺伺いしたいと思います。

遠藤 克（日大・医）尿量は，動物の大きさからす ると少い方であり，また，嗅いはマウスにみられるよう な特異的なものではない。

\section{7. 幼若および成熟イエウサギ (Japanese White Nibs の心電図 pattern ならびに測定值について}

○小柇春男, 荒井 研, 赤堀文昭 (麻布獣大), 梅沢英彦（日生研・実動研）

イエウサギを被験動物として心電図の変化を検討する 際, 幼若, 成熟あるいは性による差を明らかにする必要 があると思われる。従って生理的範囲を知る目的で無麻 酔，背位保定で A B 誘導法ならびに 胸部単極誘導法を Japanese White Nibs (J.W.N) の 5 週令の 84 匹, ㅇ 61匹, 20 週令の今 39 匹, +961匹, 合計 245 匹について 行ない心電計は時定数 1.8 秒, $1 \mathrm{mv}=10 \mathrm{~mm}$ の感度の心 電計を用いた。

A B 誘導法は家畜心電図研究会の暫定的な申しあわせ により，右後肢に接地電極を置き頸部背側中央部之剣状 軟骨部より誘導し，胸部単極誘導法は松浦らの方法によ り誘導した。

〔成績〕 1. A B 誘導法ならびに胸部単極誘導法の $\mathrm{C}_{1}$ では陽性 $\mathrm{P}$ 波， Rs 型，陽性 $\mathrm{T}$ 波。

2. 胸部単極誘導法の $\mathrm{C}_{2}, \mathrm{C}_{3}$ においては陽性 $\mathrm{P}$ 波, $\mathrm{R}$, $\mathrm{Rs}$ ，もしくはqR 型，陽性 $\mathrm{T}$ 波。

3. $\mathrm{C}_{4}$ では陰性 $\mathrm{P}$ 波, $\mathrm{QS}$ または $\mathrm{rS}$ 型, 陰性 $\mathrm{T}$ 波。 
4. $\mathrm{C}_{5}$ では $\mathrm{P}$ 波は平担, $\mathrm{rS}, \mathrm{RS}$ 型, $\mathrm{T}$ 波は平担か陰 性である。

5. PP ならびに QT 間隔は成熟において延長する。

6. $\mathrm{P}, \mathrm{QRS}, \mathrm{T}$ の持続時間は成熟に执いて若干延長し

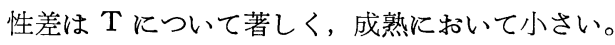

7. P, R, T の振幅は成熟に打いて低下する。

〔考察】イエウサギを被験動物として使用する際今 우 間の差の小さい成熟イエウサギを使用することが望まし いと考えられる。

[発言]

高橋 弘（実中研） 1. 無麻酔背位保定で, ウサギ はあばれませんでしたか?。また，あばれによって記録 が変化するよらなことはありませんでしたか？。2. 拉 示し頂いたデータは平均值と標準偏差でしたが, 統計的 有意差があるとされているものの中には, 多少ギモ்の ある項目(若しかしたら, 有意差はないのではないか?) もあったように思われますが，如何でしょらか？。

小林春男（麻布獣大） 1 . 無麻酔背位保定によりあ ばれは非常に少なかったが，そのようなウサギについ ては一定時間をすぎ静穏になってから記録を開始しまし た。またあばれの時点でも基線の動摇あるいは EMGが 混入する程度で, あばれの前後を含んで実験中遭遇した あばれの程度では大きい影響はみられませんでした。

2. ご指摘の平均值と標準偏差に拉ける有意差の疑問 点については，Fならびに $\mathrm{t}$ 検定を再度行って確めたい と考えています。

\section{8. 実験動物の繁殖 cycle における血液検查成績一ウサ} ギについて

$$
\begin{array}{r}
\text { 辻紘一郎, ○田村博志, 小島 操, 中村勝美 } \\
\text { (中外. 綜合研) }
\end{array}
$$

〔目的〕実験動物の繁殖, 育成を担当する立場から, 動物の生理的変動を把握しておく必要を感じ, コクシジ ウム・フリーコロニーとして生産維持している JW/CS K系ウサギの繁殖 cycle に和ける血液性状の変動につい て検討した。

〔方法】成熟 ᄋ ウサギ 7 頭について, 妊娠前 ( 2 回), 妊娠期 (4)回, 泌乳期 ( 3 回), 離乳後 ( 1 回)の計10回に わたり，ヒト用に開発された簡便で, 迅速に検査のでき る Rapid Blood Analyzerを用い, ヘモグロビン $(\mathrm{Hb})$, 総蛋白 $(\mathrm{TP})$, 総コレステロール $(\mathrm{TCh})$, 尿素窒素 $(\mathrm{BU}$ $\mathrm{N})$, アルカリフォスファターゼ(AlP) を測定し, あわ せて赤血球数 $(\mathrm{RBC})$, 白血球数 (WBC) も計測した。 〔成績及び結果〕 $\mathrm{RBC}, \mathrm{WBC}$ ともに測定值にかなり の個体差がみられ, 著明な変動はみられなかったが, $\mathrm{RBC}$ については妊娠後期に若干減少する傾向がみられ た。 $\mathrm{Hb}$ は妊娠中期より減少し始め, 妊娠後期, 泌乳前
期に最低值を示し, 以後回復の傾向がみられた。TP は 妊娠後期に著明な減少を示したが, 泌乳前期にはかなり の回復がみられ, 離乳後はもとにもどった。TCh は妊 娠後期に最低值となり, 泌乳前期には急激な増加がみら れたが，その後徐々に減少しもとにもどった。AlP は 妊娠中期に減少の傾向を示し, 後期に最低となり, 以 後, 徐々に回復の傾向を示した。BUN は各期とも著明 な変動がみられなかった。

[考察】血液性状の各変動が妊娠後期及び泌乳前期に 著明なことは興味深く, 特に妊娠後期にみられた RBC, $\mathrm{Hb}$ 減少から妊娠貧血が推定され， $\mathrm{TP}$ 及び $\mathrm{TCh}$ の 低下は栄養失調を思わせるものであった。しかしながら これらの変動は分娩前後の胎子の発育と母体の関係や分 娩の影響が母体の栄養, 代謝等に現われているものと想 像され, これらの変動はいずれもCSK 系ウサギの繁殖 cycle に持ける正常な変動と考えられた。

[発言]

奥木 実 (都老人研) 妊娠末期の貧血と栄養失調と 云はれるが栄養失調とはどの面から云えるか。

田村博志 (中外・綜合研) $\mathrm{RBC}, \mathrm{Hb}$ 減少及び TP や TCh の著しい低下が観察された結果から，血液性状 の面で解釈すると妊娠貧血や栄養失調を思わせる成績で あったが，これらの変動は妊娠期に扣ける正常な変動と 考えている。

\section{9. 組織化学的方法によるアカゲザルの排卵期の推定}

○谷岡功邦, 泉山絅子, 緒方孝康, 小泉 均 (実中研)

〔目的〕サル類の 繁殖生理に 関する研究の一端とし て, アカゲザルの月経周期に拈ける好中球アルカリフォ スファターゼ (NAP) 拉よびベーターグルクロニダーゼ $(\beta-\mathrm{GL})$ 活性の変動を調査し，これらの酵素がアカゲザ ルの排卵時期ならびに交配適期を推定するための指標に なり得るか否かについて検討した。

〔方法】規則的な月経周期を示すインド産成熟早アカ ゲザル24頭を使用した。耳染穿刺により血液塗抹標本を 作成したのち, 朝永らの細胞組織化学的方法により NAP および $\beta$-GL の定量を执こなった。また Brown の螢 光法による尿中総エストロゲンおよび, 子宮頸管粘液の 牽引度と尾根部の腫脹の度合いの測定を合わせておこな った。

[成績] NAP 活性值は通常極めて低值であったが, 月経周期の中間期に当る13〜15日のいずれかの日に明ら かな上昇（NAP ピーク）が観察された。尿中エストロ 
ゲンは月経周期の 11〜 12日に最高值を示したが，NAP のピークはこれから4 日以内に出現した。また子宮頸管 粘液の毫引度あるいは性皮の腫脹の度合いが最高值を示 した日から 4 日以内に NAP ピークが出現し，このピー ク出現日あるいはその前日に頸管粘液または性皮腫脹の 值が急下降する傾向が観察された。一方， $\beta$-GL の活性: 值は, NAPピーク出現より 2,3 日早い月経周期の11〜 12日に著明な上昇を示した。

〔考察】以上の成績から，月経周期の中間期に出現す るNAP ピークは，排卵日またはその直後の時期に相当 しているものと推定された。また， $\beta-G L$ 活性の上昇は エストロゲンの上昇時期と一致していたことから排卵間 近かの 卵胞成熟期に相当するものと推察された。NAP の定量により個体の排卵の有無や排卵の時期を推定する こと， $\beta-G L$ の定量により交配の適期を定めることが可 能であると思われた。測定方法が簡便であることから， これらの酵素の定量はアカゲザルの室内計画繁殖に応用 できるものと考える。

〔発言〕

本庄重男（予研） 醅素活性の陽性指数はかなり客観 的に正確に表現し得るのでしょうか。指数の基準を沶示 し下さればもっとよく理解できたと思らのですが。

谷岡功邦（実中研） 陽性指数は，一般に用いられて いる基準に従ってもとめました。この基準により酵素活 性值はかなり客観的に表現されていると考兵す。

\section{0. ニホンザルオスの性成熟及び生殖機能の季節変動}

和 秀雄（日本モンキーセンター）

〔目的〕 二ホンザルオスの生殖現象，特にその性成熟 々生殖機能の季節变動について, 形態学的・内分泌学的 手法を用いて明らかにすることを試みた。

〔材料及び方法〕 大分県 高崎山の二ホンザルから， mating season( $1 \sim 2$ 月)， 5 月， 6 月， 8 月，10月及 び 12 月に材料を採取した。捕獲・麻酔後, 精巣の Size を陰のうの上から計測し, その後切除法によって精巣の 一部を採取，ブアン固定，パラフィン包埋，H.E. 染色 によって組織所見を観察した。同時に，採取したへパリ ン処理の血液を遠心して plasma を採取， Radioimmunoassay によって血中テストステロンを測定した。

〔成績〕〈性成熟〉全乳歯が永久歯に拔換した時期の mating season に大部分のサルの精巣は, 組織学的に 成熟した状態を示し，また，精巣の Size 及び血中テス トステロンもこの時期に 急速に 増大することがわかっ た。

〈季節変動〉組織学的に，精巣は mating season には active であるが，5〜8月には Regression が著明に なり，10月になると Progressive な変化が生じて機能
が回復してくることがわかった。血中テストステロン も, mating season には高く, $6 \sim 8$ 月に低くなり, 10月には再び上昇してくるのが認められ，精巣の Size にも全く同様の变化が認められた。

[考察】精巣の Size の変化, 組織所見, 血中テスト ステロンの増減とも，注涪一致した成樍が得られたが, このことから，1．性成熟については，永久㐘列になっ た時の mating season そ大部分のサルが成熟する,

2. 季節変化については, 従来の生態学的な観察結果と 注济一致する生理的な变化が認められる，と結論するこ とができる。

[発言]

藤原 徹（予研） 雄ニホンザル性機能の年間変動が みられるのは，雌に対しての相対的なるのと考光ます か。また，雄の独立した現象と考穴てよいでしょらか。

和 秀雄（日本モンキーセンター） 一応オスはオス で独立した現象を示すと考㝋ています。しかし，メスの 発情がオスを刺激し，才スの性機能を高めるというょう なこともまた考觉られるとは思います。

本庄重男（予研）二ホンザルやの生殖機能の季節変 動を誘起している一番の main factor は何であると現 段階で扣考觉ですか。

和 秀雄 (日本モンキーセンター) 気温, 湿度, 日 照，食物など，いろいろの説がありますが，現在のとこ ろ，どれも立証されていませんし，私自身にも，これだ という特別の考えは今のところありません。まず，季節 変動の実態を明確にし，その上でこの問題にとりくんで みたいと考壳ています。

\section{1. アカゲザルの血液形態的, 生化学的所見の 5 ケ年間} の観察結果について

○黒沢和雄, 松島松㖕, 阿部栄四郎, 佐々木喜一郎，柳沢 正，小沢小市， 武重恒一（日本農村医学研）

〔目的〕 アカゲザルが，成長するにしたがい血液所見 にどのような变化がみられるかを調べた。

〔方法〕 アカゲザルを， 5 年間飼育し，始めの 2 力年 を前期とし， 3 力月毎に，あとの 3 カ年を後期とし， 6 カ月毎に検查した。

〔検査項目及び方法〕 午前10時頃, 空腹時に, 大腿静 脈から $5 \sim 6 \mathrm{ml}$ 採血し, 血球計算, 血色素, ヘマトク リット值については, 二重蓚酸塩を入れた小試験管に, 血清用は，スピツ管にそれぞれ採取した。血球は東重の ミクロセル・カウンターにより計測し，血色素はシアン メトへモグロビン法，へマトクリット值は毛細管法によ りそれぞれ行なった。生化学的所見については，総蛋白 は屈折法で，血清蛋白定量用の小型届折計 $D \cdot Z$ を用い 
た。 A/G 比は吉川斉藤法, GPT は Reitman-Frankel 法, 血糖值は Somogyi-Nelson 法, 尿素窒素は Diaolylmonoxime 法, 総コレステロール值は Zak-Henly 法 により行なった。

[成績及び考察〕 5 力年間を, 前期と後期とで比較し てみると, 平均值では, 赤血球, GPT, 血糖值では, 前 期より後期に明らかに低下し, ヘマトクリット，総コレ ステロール，血色素は，やや低下する傾向がみられる。

サル血液所見の比較（平均値と標準偏差）

\begin{tabular}{|c|c|c|c|c|}
\hline 検査内容 & 時期 & No. 46(令) & No. 139 (古) & No. 26(우) \\
\hline \multirow{2}{*}{$\begin{array}{c}\text { 赤 血 球 } \\
\left(\times 10^{4}\right)\end{array}$} & 䶺期 & $557 \pm 61$ & $559 \pm 37$ & $537 \pm 62$ \\
\hline & 後期 & $527 \pm 32$ & $538 \pm 34$ & $517 \pm 32$ \\
\hline \multirow{2}{*}{ 白 血 球 } & & 11 & 40 & 4,652 \\
\hline & 後期 & $9,430 \pm 1,927$ & 11,15 & 670 \\
\hline \multirow{2}{*}{$\begin{array}{c}\text { ヘマトク } \\
\text { リット } \\
(\%)\end{array}$} & 前期 & $44.9 \pm 3.3$ & $43.4 \pm 3.0$ & $42.3 \pm 2.2$ \\
\hline & 後期 & $41.9 \pm 2.7$ & $44.2 \pm 1.4$ & $40.8 \pm 2.4$ \\
\hline \multirow{2}{*}{$\begin{array}{l}\text { 血 }(\mathrm{g} / \mathrm{dl})^{\text {素 }} \\
\text { (1) }\end{array}$} & 前期 & $13.9 \pm 1.5$ & $14.2 \pm 0.6$ & $13.7 \pm 1.3$ \\
\hline & 後期 & $13.5 \pm 0.7$ & $14.7 \pm 1.2$ & $13.6 \pm 1.0$ \\
\hline
\end{tabular}

サル血液生化学的所見の比較 (平均值と標準偏差)

\begin{tabular}{|c|c|c|c|c|}
\hline 検査内容 & 時期 & No. 46(§) & No. 139 (§) & No. 26(우) \\
\hline \multirow{2}{*}{$\begin{array}{c}\text { 総蛋白量 } \\
(\mathrm{g} / \mathrm{dl})\end{array}$} & 前期 & 1.2 & $5 \pm 1.0$ & $\cdot 5 \pm 1 \cdot 1$ \\
\hline & 後期 & $0 \pm 0.5$ & $.7 \pm 0.6$ & $=0.9$ \\
\hline \multirow{2}{*}{$A / G$ 此 } & 前期 & $1.02 \pm 0.18$ & $0.82 \pm 0.16$ & \pm 0.15 \\
\hline & 後期 & $0.30 \pm 0.21$ & $0.95 \pm 0.17$ & \pm 0.10 \\
\hline \multirow{2}{*}{ GPT } & 前期 & $20.5 \pm 6.7$ & $25.3 \pm 12.1$ & $19.1 \pm 6.1$ \\
\hline & a & $12.3 \pm 2.6$ & $19.6 \pm 6.3$ & $15.7 \pm 2.8$ \\
\hline \multirow{2}{*}{$\frac{\text { 血 }}{(\mathrm{mg} / \mathrm{dl})}$} & 前期 1 & 102.2 & $96.2 \pm 17.5$ & $76.7 \pm 17.8$ \\
\hline & 後期 & $78.3 \pm 8.1$ & $81.3 \pm 8.7$ & $69.8 \pm 9.7$ \\
\hline \multirow{2}{*}{$\begin{array}{l}\text { 尿素窒素 } \\
(\mathrm{mg} / \mathrm{dl})\end{array}$} & & $19.3 \pm 3.0$ & $22.0 \pm 1.9$ & $19.4 \pm 3.3$ \\
\hline & 後期 & $22.3 \pm 2.7$ & $22.8 \pm 1.4$ & $17.0 \pm 1.2$ \\
\hline \multirow{2}{*}{$\begin{array}{l}\text { 総コレス } \\
\text { テロール } \\
(\mathrm{mg} / \mathrm{dl})\end{array}$} & & $211.4 \pm 46.7$ & $183.3 \pm 32.6$ & $169.3 \pm 20.2$ \\
\hline & 後期|2 & $200.8 \pm 43.0$ & $147.8 \pm 38.8$ & $181.1 \pm 20.9$ \\
\hline
\end{tabular}

変異係数の 比較では，前期には赤血球が $6.6 \%$ から $11.6 \%$, 自血球が $27.2 \%$ から $32.5 \%, \mathrm{GPT}$ が $31.9 \%$ から $48.1 \%$ ，総蛋白量が $13.5 \%$ か $15.5 \%$ 範囲である が, 後期には, 赤血球が $6.1 \%$ か $6.3 \%$, 白血球が 20.4 \%から $28.2 \%, \mathrm{GPT}$ が $17.8 \%$ から $32.3 \%$, 総蛋白が7.1 \%から10.9\%と，それぞれ低下し，その他にも低下の傾 向がみられた。

\section{[発言]}

田中利男（日本モンキーセンタ一） 5 力年の長い期 間に互たる検査なので，年令差を考虑しなければならな
い。前期と後期とに分けておられるが，新しい環境に順 化するまで特に白血球で変動が著しいといら報告がある ので前期を更に入荷時とその後とを細かく分けて見た場 合成績は如何でしょらか。

黒沢和雄 (日本農村医学研) 我々の第一回目の検査 は, 入荷後 6 力月以後であり, 質問に対する解答は出来 ませんが我々の 6 力月以後第 1 回採血時点でも, 初回及 び 2 回目も高い値を示した（白血球において！)。

登倉尋実（京大・霊長研） ヒトの場合血液性状の季 節変動が多くの研究者によって確認されておりますが, アカゲザルの血液性状に打いて，季節による变動はみら れたでしょらか。

黑沢和雄（日本農村医学研） アカゲザルの血液にお いては（ヒトの季節的变動，特に白血球に执いて言われ ているが), アカゲザルの場合, 特に我々の場合例数が 少ない点で問題が残されているが，季節的な変動と云う 点を見た場合特に有意の差を認めなかった。

\section{2. 実験室内で繁殖，育成したカニクイザルの血清蛋白 分画について
○川西康夫 (東西), 本庄重男, 長 文昭 (予研)

〔目的〕輸入野生ザルのコンディショニングには健康 状態を適切に把握できる指標が要求される。このため血 清蛋白分画の標準值と思われる範囲を棄却楕円をるって 表現し, 輸入野生ザルの健康管理目標への利用の可能性 を検討した。

〔方法】血清は実験室内繁殖サル群と実験室内で長期間 飼育された輸入野生ザル群から採取し, 日立血清蛋白計 で血清総蛋白量を測定した。血清蛋白分画はセルローズ アセテート膜電気泳動によった。血清蛋白分画值は各分 画の平均值を求め, 年令別・性別の差の有無を検討し た。また，アルブミン分画とノグロブリン分画の組合せ による毵却棈円を常法に従い危険率 $5 \%$ で作図し検討し た。

〔成績】電気泳動により 6 血清蛋白分画を得た。ヒト 血清と相対易動度では似ているが，ヒト血清には見られ ない第 5 分画 $\left(\beta_{2}\right.$ 分画) のあることが判った。血清総 蛋白量と $\alpha_{2}$ グロブリン分画で年令差をみとめたが性別 による差はみられなかった。輸入後 9 週を経過した野生 ザルでは一般にアルブミン分画の増量とグロブリン画 の減少が見られた。しかし，実験室内繁殖サルの棄却楕 円には輸入野生ザル群は一致しなかった。一方, 輸入野 生ザルの革却楕円には, 輸入後の経過にともない次第に 楕円内に位置し, ある群では輸入後10週経過時にその 96 \%が棈円内に位置した。

〔結論〕実験室内繁殖ザルと輸入野生ザルの血清蛋白 
成分には大きな隔りのあることが判った。一方，輸入後 10 週経過群と 3 年経過群とは同じ傾向を示した。このこ とから，実験室内繁殖サルと輸入野生ザルとを本質的に 異質なものとして取扱らべきことが示唆された。また， 実験室内繁殖サルと輸入野生ザルにもとづくそれぞれの 棄却棈円を併用すれば，実験目的に応じた条件を整省た 個体群の選抜も可能と考光られる。

\section{〔発言】}

和 秀雄（日本モンキーセンター）輸入野生サルと 実験室内育成サルとがやや違う傾向があることはわかり ましたが，健康といら概念との関連では，どちらがょり 好ましい状態と考兄られますか。

川西康夫（東西）どちらの群が健康であると断定す ることは難しいことです。それは, ジャングルにいる野 生ザルと実験室内で繁殖育成したサルと，いずれが健康 なサルか，といらことに拈答えすることになると思いま すが，いずれの群も健康といえると思います。

すなわち，サルの側からみれば，野生の状態が最も彼 等の生活に適した環境であり, サルは健康な生活を送っ ているといえるでしょうし，使用者の立場からすれば， 使用の目的に応じて使用者が設定した条件を満たせるも のを健康なサルとしているといえると思います。

ただ実験条件を整える上からは，実験室内繁殖育成少 ルを採り上げるべきであるとは考觉ますが，此較実験に よるはっきりした成績をもっていないので，今は両群の いずれが好ましい状態にあるかはお答えできません。

本庄重男（予研）沶示しした妄却楕円(Alb- $\gamma \cdot \mathrm{Glb}$ ) にもとづいてみる限り, 野生由来の繁殖早群と実験室繁 殖群とは質的に異るものと, 私達は考えています。御質 問のどちらが健康かといらことについては，今後行動 面, 性活動等の観察もらくめて健康の概念を正確に規定 したうえでないと，はっきり敃答えできません。

\section{3. 育成カニクイザルの成長について}

○長 文昭, 藤原 徹, 吉岡幸雄, 中山 満, 本庄重男（国立予研・獣疫部）

〔目的〕野生妊娠早から生まれたサル（以下W）と, ケージ内受胎早から生まれたサル (以下Y) の成長状態 について検討した。



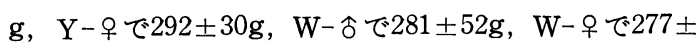
$71 \mathrm{~g}$ であった。その後, Y-合では 6 才（約 $7 \mathrm{~kg}$ ）まで ほぼ直線的に増加し，Y-早では 5 才前後で plateau （4〜4.5kg）飞達する傾向がみられた。Wでは, 各測 定年令間の増加率にかなりの差があると同時に， 今， 古

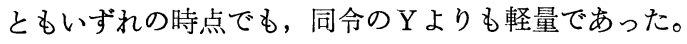
体長：出生時の体長は, $\mathrm{Y}-\hat{o} て ゙ 16 \mathrm{~cm}, \mathrm{Y}-$ o で17cm,
6 力月令では, $\mathrm{Y}$-令, 古とも, 約 $24 \mathrm{~cm}$ であった。 $\mathrm{Y}$ と $\mathrm{W}$ との間に著しい差は認められなかった。その後, 古, 占とも 5 才前後で plateau (約 $45 \mathrm{~cm}$ ) に達する傾向が らかがわれた。歯牙萠出: 下顎で乳歯の第一門歯は, Y 一へでは18日令, Y-Oでは12日令頃に生えた。乳藏第一 小臼歯は Y-令, 古とも74日令頃に生光, この頃に固型 飼料を食べられるようになった。永久歯の第 3 大曰歯は $\mathrm{Y}$ 一个, 早とも 5 才半位で生光た。各上顎歯は対応する 下顎歯とほぼ同じ頃萠出した。 W時期はYに比べてバラッキが大であった。性成熟：23例 の $\mathrm{Y}-$ 早での初潮発現の時期を集計した結果, 平均 2 才 6 力月土10力月令であった。Y-占で, 精巣の大きさ, 電気射精能，精巣組織所見等を総合して，4才令から 5 才令までの 1 年間は未熟期から成熟期への移行期であり 5 才令以後が成熟期であると判断された。

〔考察〕以上の諸成績は，WサルよりもYサルの方が, 概してすぐれた成長をすることを示している。母体がよ く実験室環境に適応している故であろう。一般に成長の 良否は, ケージの大小, 飼料の量・質, 仲閒のサルとの 触れあい等々種々な条件との関連を無視しては論じ得な い。これらの点については今後改めて検討したいと考兄 る。

\section{[発言]}

田中利男（日本モンキーセンター） YとWとでは初 潮発現時期に差異はみられなかったか。

長 文昭 (予研) YとWとの平均値間には, 統計的 に差が認められた。平均值, 標準偏差值および例数を附 記する。Y：Av. 2 才 158.4 日令, S. D. 300.3 日, No. 16。W : Av. 2 才 268.9 日令, S. D. 379.7日, No. 7 。 及川弘（塩野義・油日）歯の萠出日に上顎と下顎 および左側と右側で差がみられますか。

長 文昭 (予研) 統計的飞処理していませんので, はっきり申し上げられませんが, 上顎と下顎間では, 永 久歯の第一大臼歯に， ○で73日（下顎が早い），守で43 日（下顎が早い）の差があり, これらが日数的には, 大 きい差といえます。今後, 統計的に処理をして, 詳しい データーの報告をしたいと考劣ています。なお私ども は, 左側についてのみ観察をいたしましたので, 左右の 比較は, 残念ですが出来ません。

\section{4. 妊娠カニクイザルの血液諸性状}

○藤原 徹, 須崎百合子, 矢部美機子 吉岡幸雄, 栗原金治, 本庄重男（予 研)

〔目的〕一般に，動物の妊娠時の血液諸性状は，非娃 時のそれらと比較してみた場合, いくつかの点で異なっ ている。したがって，血液諸性状の検査によって妊娠動 
物の健康状態を判定する際には, あらかじめ正常妊娠経 過をたどる動物でのそれらの值の変動を知って扣く必要 があるとい方る。このような観点から，今回われわれは カニクイザルの妊娠初期から分姺後 8 週に至るまでの間 に, 各種血液性状でどのような変動がみられるかという ことを検封した。

[材料拈よび方法】動物は東南アジア各地から輸入さ れた成熟雌カニクイザルで，妊娠例（延27例）は月経周 期第11日から 7 日間の 1 対 1 ケージ内交配によって得 た。対照例（9例） も月経周期正順動物である。血液検 査項目は, 赤 - 白血球数, $\mathrm{Ht}$ 值, $\mathrm{Hb}$ 量, 血清総蛋白量 (以上 5 項目は妊娠偶数週に検查), トランスアミナー ゼ値, コレステロール量, 血沈值, 血清比重 (以上 4 項 目は妊娠末期には 0.5 週間隔で検査）の 9 項目である。 飼育管理条件は予研の日常管理方式にしたがった。

\section{〔成績および考察〕}

妊娠期間中ほぼ全期間にわたり，軽度の貧血，白血球 減少, 比重の低下, 総蛋白量の低下抽よび著明なコレス テロール減少などが認められ，また，妊娠末期には血沈 促進が目立った。な招，これらの所見は分娩後 4 週目に はほとんどすべて非妊時の状態に復した。さらに，全妊 娠例が正常仔を正常分婏していることからわれわれの飼 育管理条件下にあっては, これらの血液性状の変動は娃 娠カニクイザルにとって生理的なるのとみなされる。他 報告にみられる妊娠了カゲザルの血液性状变動パターン は，われわれが得た妊娠カニクイザルのそれらとほぼ一 致するが，妊婦のそれらとくらべると，白血球数括よび コレステロール変動パターンに招いて違いがみられ，こ れらの点は今後の研究課題であると考えている。

\section{[発言]}

和 秀雄（日本モンキーセンター） 1. 妊娠サルと非 妊娠サルの差は統計的にも有意差が出るでしょらか。二 ホンザルの場合には, 殆んど非妊娠サルを含めたバラツ キの中に含まれてしまらのですが。2. 血沈は全例に括い て増加するるのでしょらか。二ホンザルでは, ふえるも のとふえないるのがあるのですが。

藤原 徹 (予研) 1 . 統計的に有意差があるかどらか 調ベてありませんが，血沈，コレステロールなどは特に 調べるまでもなくあると云えると思います。また，非妊 対照群の值の動きと比較判断して, かなりの程度に統計 的有意差があるとみてよいと考えて扬ります。2.カニク イザルでも妊娠末期に血沈が促進しない例もありまし た。特に数值は示さなかったのですが, 標準偏差值が大 きくなっていることから执かかと思います。

\section{5. 乳幼児のモデルとしての仔ザル（カニクイザル）の 人工飼育実験}

○畠山富而, 若生 宏, 上原充郎, 和田幸子 (岩手医大), 本庄重男, 藤原 徹, 長 文昭 (予研)

〔目的〕近年, 低栄養と脳発達の問題が実験的, 臨床的 研究として大きな関心を呼んで和り, 特に脳の DNA, RNA さらに myelination の研究が中心となって来て いる。臨床的にも乳幼児期に沏ける低栄養は時に永続的 不可逆的傷害を脳に残すことが指摘され，その程度は幼 若なほど大きいと云われている。私達は幼若な時期の栄 養を低栄養（主として蛋白質）にする実験を行うため， その前段階として仔ザルの人工飼育実験を行った。同時 に現在問題になっている isolation monkey について も観察を行っている。

[方法] 野生妊娠, 予研繁殖で予研にて出生した各 3 頭, 4 頭であり合 3 , ㅇ 4 である。出生後, 岩手医大動 物舎内の未熟児保育器内のケージ $\quad(25 \mathrm{~cm} \times 35 \mathrm{~cm} \times 30 \mathrm{c}$ m) 飞移し室温, $25^{\circ} \mathrm{C}$, 湿度 $60 \%$ とにして, ケージの 中に直径 $5 \mathrm{~cm}$, 長さ $15 \mathrm{~cm}$ の枕様のものを作り常時入れ た。ミルクは育児用特殊調製粉乳，雪印P7aであり $12 \%$ にて使用した。哺乳方法を 2 群に分け，手の上にて抱い て与えた例とケージに哺乳ビンを差込んだ例に分けた。

〔成績】身体発育（主として体重）は予研発表の予研 繁殖育成ザルと同程度から上廻った状態を示している。 カニクイザルの母乳の分析を急いでいるが，哺乳量から 栄養計算を行らと離乳期前の栄養は，カロリー，200〜2 $40 / \mathrm{kg}$ /日，蛋白質， $7 \sim 8 \mathrm{~g} / \mathrm{kg}$ /日，水分， $400 \sim 450$ $\mathrm{ml} / \mathrm{kg}$ /日であり, $100 \mathrm{ml}$ 中 2.0 の蛋白量では哺乳は著 明に低下した。習性, 行動発達については, 猿の精神病 理学が人間とのかかわりあいの中で話題になっているが 私達の isolation monkey は self-Clasping, autistic self-mouthing, stereotype rocking, huddling, knocking, aggressive behabior, fear などの異常行動 が認められ，特にケージの中に哺乳ビンを差込んで哺乳 を行った例に傾向が強い。なお，1例であるが低蛋白栄 養例が成育していることを附記する。

[発言]

登倉尋実（京大・霊長研） 低蛋白摂取が脳の発達に 障害を扣よぼす研究をおこないたいと講演抄録に書いて ありますが，どらいう方向でアプローチされようとし て，いらっしゃるのか，打教光下さい。

畠山富而（岩手医大）脳組織の部位ごとの DNA, RNA の測定, 細胞数, myeline の状態を sulfatide によりアイソトープの取り込みにより,ささら組織化学 的にも追求する。 


\section{6. 前面可動挾体式サルケージについて}

○長 文昭, 小川房雄, 本庄重男

(予研)

われわれは, 前面可動挾体式ケージを以下のような要 求を充すために考案製作した。安全かつ手間のかからな いこと, 同時にサル自身を傷つけることなく, 清潔を容 易に保持することが出来ること。

前面可動式挾体ケージの構造の概要は, ケージ前面に サル出し入れ口のついた正面枠を前面から後面まで, ケ 一ジ内の四隅を通して設けた鉄棒をレールとして，後面 に移動させ，それによってサルをケージの後壁に押しつ けるものである。

この前面可動式㣣体ケージは, 従来, 内外で使われて いる㣣体板が後から前方に移動して，サルをケージ前面 で㣣む方式のケージと比べ，次のような利点を有してい る。

第一に，ほとんどのサルは，ケージの奥に逃げ込む性 質を持っているが，この性質に逆ららことなく，手易く 㣣むことが出来る。

第二に，長い柄の捕獲網を使わずに捕えることができ るので, 從来捕獲に必要であった広い作業空間もせまく て済み，かつ捕獲網を介する各種の感染の拡延を防ぐ結 果となる。

第三に, 従来の㣣体ケージでは, 挾体板とケージの後 面との間に洗滌の出来ない部分があったが，この点, 前 面可動挾体式ケージでは, 構造上, 洗涤不可能な部分が なく，容易に清潔が保持出来る。

\section{[発言]}

山口健二（塩野義・研） 御発表の猿ケージの価格を 教えて下さい。

長 文昭 (予研) W40×D $50 \times \mathrm{H} 58(\mathrm{~cm})$ の組立式鉄 製ケージで 18,000 円です。又，材質と大きさにより価 格は異りますので, 詳しいことは, 昭和科学器械製作所 (Tel. 03-604-6677) 飞扮問合せ下さい。 登倉尋実（京大・霊長研） サルを麻酔しないで，ケ ージからケージへ移動する場合, 前面可動面にキャリン グケージを固定し, 前面可動面を後面に動かすのでしょ らか。もしそらであれば，その際サルが前面の格子につ かまり，素直にキャリングケージに入らないといらこと が考兄られないでしょらか。

長 文昭 (予研) 前面可動面汪キャリングケージ （捕獲箱）を取りつけて実施したことは未だないので判 りません。私どもでは, 単体ケージでのみ, ケージ側面 に, 捕獲箱を取付けて，サルを追込む方法で成功し，実 用化しています。御質問の件については，今後検討した いと考えています。
谷岡功邦（実中研）三段重妏式 Cage の使用結果は いかがですか。

長 文昭（予研） 三段目については，現在付属品を 準備していますので，未だ使用経験を，扮話しすること が出来ません。

\section{7. 輸入サルにおける下痢の出現状況と治療}

○高阪精夫, 本庄重男, 諸田 栄, 加園武芳, 阿部宣子, 中条江美子（予研）

〔目的】実験用サルの検疫および健康管理の立場から サルの主要な疾病は下㢉であると思われる。今回は, サ ルに扣ける下痢の実体を正しく把握し, 予防拈よび治療 方法を改善する目的で，検疫期間中に怙ける下峲の出現 状況と治療処置について報告する。

〔方法〕昭和 46 年 3 月から 47 年 8 月までの間に入荷し た 1,055 頭のカニクイザル（以下サル）について，7〜 11週間の検疫期間中に和け下痢の出現状況を調査した。 治療には, rifampicin (以下RFP) と chloramphenicol（以下 CM） とを使用し，前者では，細菌性赤痢 （以下赤永）ザルと赤峲以外の下㢉ザルで, 後者では, 赤㢉ザルで治療を試みた。

[成績及び考察】 (1)輸入ザルの検疫期間中に抽ける下

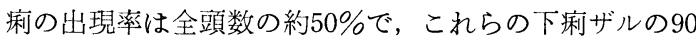
$\%$ \%荷後 4 週間以内に出現した。また，入荷後 1 週間 以内の出現率が最も高かった。産地別にみた下㢉出現率 を多い順から記載すると,フィリピン産, マレーシア産, インドネシア産となる。季節別にみると, 夏と秋との入 荷群の下峲出現率は, 春々冬との入荷群のそれより高率 であった。各年令層間では，下峲出現率に差は認められ なかった。(2)治療法に拈いて，第1飞RFPを1頭 1 日 当り $200 \mathrm{mg}$ 索 3 日間連続経口投与し，投薬開始後30日 間観察したところ，投薬開始後 7 日以内に下痢が消失 し，その後下痢の再発がなく治癒した例は，赤麻ザルで $75 \%$ にられた。一方非投薬群での赤痢自然治痹率は10 \%にすぎなかった。また，赤㢉以外の下㢉ザルの投薬群 での治痖率は約 $55 \%$ ，非投薬群の自然治癒率は約 $56 \%$ で あった。第 2 にCMを全量で $1,000 〜 2,000 \mathrm{mg}, 3 \sim 8$ 日間に分け赤㢉ザルの筋肉内に注射したところ，CM感 受性菌の赤痢でも, 耐性菌が出現し, 治癒しない例があ った。な括，今後，下痢と原因との関係をさら飞究明 し，それぞれの下㢉に対応して予防および治療法を改善 して行きたい。

[発言]

井戸阪弘巳（阪大・微研）リファンピシンの筋肉内 注射はやられましたか? 。

高阪精夫（予研）リファンピシンは内服剂として開 発されたもので，注射製剤はありません。したがって， 
筋肉内注射は実施しませんでした。

田中利男（日本モンキーセンター）リファンピシン を治癒しなかった例で，3日間以上経口投与をした例は ありませんか。

高阪精夫（予研）今回は, リファンピシンを，3日 間連続経口投与する方法での成績に限って報告しまし た。その他，3 日間連続経口投与でも治癒しない細菌性 赤痢以外の下痢例について,さらに投与期間を延長して みましたが，まだ例数が少ないため，治療効果を評価す るだけの成績は得られていません。

r リ

38. ニホンウズラの血球抗原に関する研究 1 . “ $K ”$ 凝 集原に関する研究

水谷 誠（日生研・夷動研）

前回, 雄ウズラ血球, 休産雌ウズラ血球はダイズ $\mathrm{PH}$ A で凝集し, 産卵雌ウズラ血球は個体によって凝集する ものとしないものとに区分されること，ならびにこの反 応でダイズ $\mathrm{PHA}$ が $37^{\circ} \mathrm{C}, 27^{\circ} \mathrm{C}$ より $4^{\circ} \mathrm{C}$ で最も強く 反応することを報告した。今回はこの凝集原…仮に“K” 凝集原と命名…の性質調査ならびに遺伝子分析の目的で 実験を行らとともに，ダイズ PHA の性質についても更 に検討を進めた。ダイズ $\mathrm{PHA}, 90^{\circ} \mathrm{C}, 30$ 分加熱で凝 集性を失ない，硫安 $90 \%$ 飽和で沈澱し， $\mathrm{SB}^{+}$(産卵特 $\mathrm{K}$ 陽性）和よびSB-（産卵時 K㓌性）系の産卵䧳ウズラ血 清によって凝集性は抑制されなかった。また，七面鳥， アヒル血球においても凝集する個体としない個体を区分 した。“ $\mathrm{K} ”$ 凝集原は胎児期, 育成期を通して系統, 雌雄 に関係なく存在したが, SB-系に拈いてふ化 $1 \sim 2$ 週令 時に凝集性が弱くなり,なかには㓌転する個体も見出さ れた。産卵開始 1 週間前にSB-系に沶ける雌血球凝集性 は消失し, 産卵中, 凝集性はみられなかったが, 産卵停 止とともに再び凝集性があらわれた。しかしSB+系に拉 いてはこのような現象は観察されなかった。“ $\mathrm{K} ”$ 凝集原 の消失とエストロジエンの関係を 3 週令時雛に diethylstilbesterol $5 \mathrm{mg}$ を胸筋内に注射して観察したが， S B- 系では 1 週間後に凝集性は消失し， 2 週間後に回復 した。しかし SB+系に拈いては変化はみられなかった。 胎児期，休産期および雄の凝集原は吸収テストにより調 查したところ同一であった。遺伝子分析は産卵時に凝集 性が消失することが優性に遺伝することを示唆した。以 上の結果から“ $\mathrm{K} ”$ 凝集原はウズラの一生を通して存在 し, 産卵時のみSB-系に拈いてエストロジェンの作用に より凝集性が消失する。このことは“ $\mathrm{K} ”$ 凝集原が消失す るためか, 他の凝集原によりマスクされるためなのかを
意味し、ニワトリに持ける“Ph”凝集原との比較で，今 後検討したい。

[発言]

近藤恭司 (名大・農) 胚の血球は, どの時期からみ たか。胚の血球は, 血球出現時から十か。

水谷誠（日生研・実動研） ふ卵 7 日目の血球から 調べましたが全て十でした。

39. ニワトリのコクシジゥムに対する感受性について

(1) Eimeria tenella および E. acervulina に よる発病回復の過程について

○及川 弘, 川口陽資, 吉田英子, 奥沢良子 峰下銕雄（塩野義・油日）

ヒナを使って楽剤の効力試験を行う場合, 效力の判定 にはヒナの品種, 系統さらには銘柄の差が変動要因の一 つになると考えられる。とりわけ感染防御の実験では, ヒナの被験病原体に対する感受性と被験薬物に対する反 応性とが複雑に影響しあった演出型が具現されるものと 推定される。

我々は，抗コクシジウム剂の検定の場合を例に, ヒナ の品種，系統銘柄によってコクシジウムに対する感受性 ならびに薬物に对する反応性にどの様な差がみられるか を調べているが，今回は基礎試験として 8 日令のヒナに E. tenella ならびに E. acervulinaを人為的に一回感 染させた場合の発病回復過程にみられる臨床症状や病態 生理的変化について, 感染後のどの時期に, どんな項目 を調べるのがよいかについて検討を行った。

E. tenella では, 感染 5 日目に症状が重く, 8 日目 には回復に向い, E. acervulina では, 感染後 5 日目に 症状が重く, 10日目から回復に向うので,これらの日に 剖検して調べるのがよい。また，検查項目としては，体 重, 掑食量, 飲水量, 糞の性状 (血便, 粘液便), 赤血 球数（又はへモログビン又はへマトクリット值），血獎 蛋白濃度, 二, 三の藏器重量 ( $\mathrm{E} . \mathrm{t}$ では特に脾重), 消 化管病変 (特に E. t ) などは, 測定法が簡単で, しか も症状の経過をよく表わすものであることを認めた。

\section{0. ニワトリのコクシジウムに対する感受性について （2）産卵鶏白色レグホンの銘柄間の差について}

○及川 弘, 川口陽資, 吉田英子, 奥沢良子 峰下銕雄（塩野義・油日）

産卵䊿鳥白色レグホンの 4 銘柄 (Dekalb, Babcock, HyLine, Starcross) について 7-10日令のヒナに Eimeria tenella の感染オーシストを $1 \times 10^{4}$ または $5 \times$ $10^{4}$ 羽, E. acervulina の感染オーシストを $5 \times 10^{5}$ ま たは $5 \times 10^{6} /$ 羽感染させ, 感染後 5 日 8 日 (E. t ), 10日 (E.a) に剖検して, 体重, 蔵器重量 (体重比重量). 
モグロビン, 血漿蛋白濃度, 盲腸病変, オーシス卜産能 を調べた。

感染によって変化のみられた項目は， E. $\mathrm{t}$ では体重 $(\leftarrow)$ 死亡率 $\left(5 \times 10^{4}\right.$ 感染の及), 肝重 $(\uparrow)$, 脾重 $(\uparrow)$, 盲腸病変, 血色素濃度 $(\downarrow)$, 血嶈蛋白濃度 $(\downarrow)$ であった が，銘柄間で差の認められたのは，出血による血色素濃 度, 血獎蛋白濃度括よび死亡率であった。他方 E．ａ で は感染による影響は, 体重 $(\downarrow)$, 肝重 $(\uparrow)$, 心重 $(\downarrow)$, 血墏蛋白濃度 $(5$ 日目り)にみられ，1銘柄で 5 日目の 心重が著しく低かった他は銘柄間に差を認めなかった。 したがって，二，三の所見で銘柄間に差の認められると しても，全体的にみると特定の銘柄でコクシジウムに対 する感受性の強いものはなかった。

また，コクシジウム感受性と薬剤に対する反応性と比 較するため, Sulfisomegole の急性毒性（腹腔内）を 上記銘柄間で比較した。 $\mathrm{LD}_{50}$ は, $1,010 \sim 1,400 \mathrm{mg} / \mathrm{kg}$ で著差はなかった。投薬後の增体重に対する影響の強く でる銘柄があったが，このことは，急性毒性を調べる場 合に $\mathrm{LD}_{50}$ だけでなく, 体重の変化も追跡する必要性を 示唆する。

\section{[発言]}

近藤恭司（名大・農） 銘柄として各群をとりあつか って扔られますが，それは商標のような意味であり，必 ずしも一つの品種といらょうな意味ではないので, 注意 を要します。

及川弘（塩野義・油日）今回のテストは市販の七 ナを購入して感染実験あるいは薬理実験を行う場合に, 所謂「銘柄」により反応性に差が有るのか無いのかにつ いて現状調査することを目的としたものであります。し たがって「銘柄」と云う用語を使いましたが「商標」と 同義と考兄ます。「銘柄」を実験動物の分類学的にはど ら扱つたらよいのか今後の問題として残されますが，現 にこれらが各種実験に使われているので, その病原体に 対する感受性あるいは薬理学的な特徵を明らかにしてお くことが望まれます。

\section{疾 病と異 常}

\section{K K マウスの離乳時体重と高血糖発症との関係}

○嶋川幸三, 古野厚次, 松尾隆夫 (武田薬品・中央研)

〔目的〕 KK マウスは肥満と高血糖を発症する性質が遺 伝しているとされているが，その性質の発現は環境に対 して敏感である。すなわち, 通常の固型飼料下，あるい は群飼での KKは高血糖の発症はまれであるが，固型飼 料より $20 \%$ カロリ一含量の高い半合成飼料で飼育する と，著明な体重增加を示し高血糖を発症する。これらの
事実から，体重増加，あるいは肥満が高血糖発症の重要 因子であると考劣る。今回は adult の体重に重要な影 響を示すと考えられる離乳時体重と高血糖発症との関係 を検討した。

〔方法〕 $\mathrm{KK}$ マウスの平均同腹仔数である $5 \sim 7$ 匹の 同腹子群より, 生後 3 週時に雄71匹を集め, 体重の大き い方から17匹，小さい方から15匹を選び，2 群とした。 この 2 群を上述の高血糖を誘発する半合成飼料で 20 週令 まで飼育した。

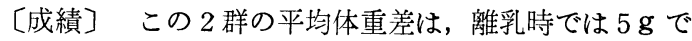
あったが，20週令では $7 \mathrm{~g}$ となり，体重差は大きくなっ た。体重の小さい群の平均血糖値は実験期間中160～180 $\mathrm{mg} \%$ であったが，体重の大きい群では $260 \mathrm{mg} \%$ と高 く, 以後, 加令々共に增加した。20週令で, 体重と血糖 との相関を求めると，各群あるいは全例のいずれに执い ても，体重増加と血糖上昇との間に有意な正の相関を認 めた。

〔考察〕 以上の結果から，KK マウスの高血糖は体重 増加に支配され，離乳時体重差は，adult の体重につな がり，その結果，高血糖発症に影響すると考えられる。 したがって高血糖症の KKマウスを作るには, 哺乳, 飼 料, 飼育の一環したコントロールが重要である。とはい 光, 体重の大きい(肥満) $\mathrm{KK}$ マウスは不稔の傾向があ るので，实験用動物と繁殖用動物とを区別する管理法が 必要であろう。

\section{[発言]}

吉田元一（信大・農）体重の中間群に拈ける体重と 血糖值との関係を調べておられたら教えて頂きたい。

沜川幸三（武田薬品・中央研） 本突験では中間群に ついて調べなかったが，他の実験で離乳時体重の大きい A 群とほぼ一致する結果を得ている。

小林孝好 (ヘキスト・ジャパン) A 群に入れたもの の中で種々の飼料制限を行なった場合に，その体重及び 血糖値等への影響はどのようになるか。

松尾隆夫（武田薬品・中央研） 飼料制限により $\mathrm{KK}$ マウスの糖尿病状態は軽減あるいは消失した。すなわち 自由採食群の体重 $(\mathrm{g})$, 血糖值 $(\mathrm{mg} / \mathrm{dl})$, 血漿インス リン值 $(\mu \mathrm{U} / \mathrm{ml})$ が $36 \pm 0.6,249 \pm 6,521 \pm 64$, であっ たのにたいし，飼料摂取量を25あるいは $50 \%$ 减らして， 4 週間飼育した群の体重は $31 \pm 0.5,25 \pm 0.3$ 血糖值は $144 \pm 7 ， 137 \pm 10 ，$ 血墏インスリン值は $168 \pm 18 ， 68 \pm 6$ とそれぞれ低下した。耐糖力，インスリン感受性も25\% 制限群では部分的に，50\%制限群では対照の ICR マウ スと同じレベルまで改善された。 


\section{2. 肥満マウスの $\alpha$-glycerophosphate generating enzyme について}

○小林克祐, 松下 宏 (和歌山医大),

遺伝性肥満マウス $\mathrm{C} 57 \mathrm{BL} / 6 \mathrm{~J}^{-}-o b, \mathrm{C} 57 \mathrm{BL} / \mathrm{KcJ}-d b$, $\mathrm{C} 57 \mathrm{BL} / 6 \mathrm{~J}^{-} A y$ に於て前二者は種々の代謝異常が知られ ている。一方 $A y$ 肥満マウスは軽度の耐糖能の低下程度 しか知られていない。

これらの肥満マウスの肝, 白色及び褐色脂肪組織で, $\alpha$-glycerophosphate generating enzyme である glycerokinase (Glyk), $\alpha$-glycerophosphate dehydrogenase $(\alpha-\mathrm{GlyDH})$ 及び glucose-6-phosphate dehydrogenase (G6PDH) 活性を 3 力月令のマウスで 測定した。

いずれの肥満マウスに於ても白色脂肪組織では $\alpha-G 1-$ $\mathrm{yDH}$ 及び $\mathrm{G} 6 \mathrm{PDH}$ 活性が非肥満対称マウスの約 2 倍の 活性を示した。肝に於ては $o b$ 肥満マウスに於てのみ G1$\mathrm{yk}$ 活性が非肥満マウスに比し軽度高值を示したがその 他に特に大きな変化はみられなかった。

fasting 及び refeeding による上記酵素の肝白色脂 肪組穖に拉ける活性変動は肥満マウスに於て軽微であっ た。

褐色脂肪組織では白色脂肪組織に比し $\alpha$-glycerophosphate generating enzyme 活性が非常に高い。ob 肥満及び $d b$ 肥満マウスに於ては非肥満対称マウスに比 し両酵素の活性が非常に低值を示した。一方我々は褐色 脂肪組織の $\alpha$-glycerophosphate generating enzyme は非肥満マウスに於て寒冷下でその活性が著明に上昇す ることを見出した。 $o b$ 肥満マウスは寒冷に対する抵抗 性が非常に低いことが知られているので，上記各種肥満 マウスは寒冷下，これらの酵素が褐色脂肪組織に於てど のように活性変動を示すかを調べた。

$o b$ 肥満及び $d b$ 肥満マウスは $4^{\circ} \mathrm{C}$ 寒冷下で約 10 㭙間で すべて死如さらに上記酵素の寒冷下に於ける活性上昇 もほとんど見られなかった。一方 $A y$ 肥満マウスは寒冷 抵抗性が強く，上記酵素も非肥満対称マウスとほぼ同様 の活性上昇をみた。最近 $\mathrm{C} 57 \mathrm{BL} / 6 \mathrm{~J}-o b$ 及びC $57 \mathrm{BL} / \mathrm{KS}$ $\mathrm{J}-d b$ マウスの視床下部の異常が問題となって来ている が，これらのマウスの褐色脂肪組織の異常との関連性は 非常に興味のある事実である。

\section{[発言]}

渡辺民朗（東北大） 1 . 高冷暴露は何度で行いまし た。2. Fasting, Refeeding の時間はどの位ですか。

小林克祐（和歌山・医大） $1.4{ }^{\circ} \mathrm{Cで} 4$ 匹を一群と して同一ケージ内に入れ行いました。2. Fastingは24 時間, Refeeding は24時間 Fasting の後, 24時間 fed ad lib. の状態で24時間行いました。

\section{3. 遺伝性筋菱縮症マウスのクレアチン代謝異常につい $\tau$}

○过 繁勝, 大亦順子, 保田龍男

（和歌山医大）

ヒト筋萎縮症の疾患モデルとして知られている遺伝性 筋萎縮症マウス $\left(\mathrm{dy} / \mathrm{dy}\right.$ 及び $\left.\mathrm{dy}^{2 \mathrm{~J}} / \mathrm{dy}^{2 J}\right)$ のクレアチ ン代謝に就いて検討を行なった。血清中及び骨格筋中の $\mathrm{CPK}$ 活性は $\mathrm{dy} / \mathrm{dy}$ マウスでは共に上昇が認められた が, $\mathrm{dy}^{2 \mathrm{~J}} / \mathrm{dy}^{2 \mathrm{~J}}$ マウスでは，血清中での活性上昇は認め られたが骨格筋中での有意な变化は認められなかった。 骨格筋中 CPK 活性の両マウスでのこの差異は恐らく実 験に使用されたマウスの月令差 $(\mathrm{dy} / \mathrm{dy}$ は生後 3 力 月, $\mathrm{dy}^{2 J} / \mathrm{dy}^{2 \mathrm{~J}}$ は生後 6 力月のものが用いられた） に 依るものと考劣られるが，いずれにしてもヒトの進行性 筋ジストロフィ一症に見られる血清中 CPK 活性の著し い上昇との類似性が注目される。又尿中及び骨格筋中で のクレアチン出納に就いて検討した所，両マウス共に正 常対照に比較して尿中クレアチン排泄量が高く，骨格筋 中クレアチン保有量が著しく低下している事が認められ た。この事から萎縮筋でのクレアチン保持に久陷が在る 事が予測される。一方クレアチン合成能自体も低下して いる可能性に就いても検討を加えた所，クレアチン合成 系酵素の一つである腎臓中グリシン，トランスアミディ ナーゼ活性が，両マウスで共に著しい低下を示している 事が見出された。更に細胞膜からのクレアチン遊出の可 能性を検討する為, 膜の NaKMg-ATPase 活性を測定 した所，筋萎縮症マウスの赤血球膜標品では正常対照よ りも高い活性值を示めしていた。以上の実験結果から $\mathrm{dy} / \mathrm{dy}$ 及び $\mathrm{d}^{2 \mathrm{~J}} / \mathrm{dy}^{2 \mathrm{~J}}$ 筋萎縮症マウスは症状の進行程度 に多少の差異はあるが, 共にクレアチン利用, ATP 利 用の面で機能異常を有している事, 又その原因として(1) クレアチン合成能力が低下している事及び(2)骨格筋細胞 に於けるクレアチン保持の能力に欠陥がある事の両方が 存在する事が確認された。

\section{[発言]}

坂口 孝（ヘキスト・ジャパン） 1. dy/dyマウス で Nak-ATP ase 異常とクレアチン代謝異常のいずれ が先行するのですか。2. マウス遺伝性筋萎縮症の pathogenesis を明らかにするためにも, その各病変像の 出現の遅速を検討される事を希望します。

辻 繁勝（和歌山医大） 1 . 幼弱期のマウスを用い た実験を行なって居りませんので確実な御答えをする事 は出来ません。唯 NaK-ATP ase 異常は赤血球膜で認 められた現象ですので, 膜の構造がどの臟器でも基本的 に同じであると仮定すれば,筋膜に於ても先天的に $\mathrm{NaK}$ -ATP ase の異常が存在する可能性が考えられると思い 
ます。2. 御説には, 我々も全く同感です。この研究で の我々の最終目標は $d y$ 遺伝子の発現機構を知る事です ので, 通常の発現症状の整理を行ならと同時に, 胎児期 に於ける異常の存在をも追求して行きたいと考兄て居り ます。因久に現在の所, 受精後18日の胎児で舌の筋肉に Coagulation necrosis が認められているのが最も早 い時期の異常と考光られて居ります。

\section{4. ビタミン $\mathrm{E}$ 欠乏飼料給与マウスにおける胎児の異常 形態について}

中村経紀，○村田義彦（麻布獣大）

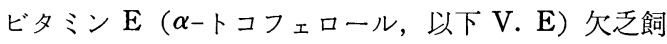
料給与により妊娠胎児に奇型を起させることがマウス， ラット, シチメンチョウ等で報告されている。演者らの 一人は, 先に本研究会に拈いて, 同飼料給与マウスに招 ける生殖細胞への影響について報告したが，今回は，同 飼料を妊娠マウスに給与した結果, 奇型胎児と同時に, 奇型産仔をも得ることが出来たので報告する。

即ち, 生後25日で離乳した $\mathrm{CFW}$ 系の雌マウス30匹を 供試して, 各々10匹宛 3 群に別け, 各群毎に, V. E 欠 乏飼料 (E欠), V.E 添加飼料 ( $\mathrm{E}$ 入), 市販固型飼料を 給与して成熟させるとともに，雌と同一飼料で育成され た雄を 2 回に別けて同居交配させた。1 回目の交配は出 産を目的としたもので, 体重の変化と娃娠の 経過を追 い, 得られた産仔の形態を観察した。2 回目の交配で は, 妊娠中途で剖検して, 子宮内胎児の有無と得られた 胎児の形態を精查した。

その結果, 1 回目の交配で, $\mathrm{E}$ 欠群は10匹の内 7 匹に 妊娠を確認したが, 出産したのは 2 匹の親の及であり, 産仔数は合計 5 匹であった。そして，その内の 3 匹に肢 指の異常を認めた。一方, $\mathrm{E}$ 入群では 7 匹（3 匹は事故 死）中 7 匹とも妊娠を認め, その内 5 匹が出産した。産 仔数合計は26匹と多く, 異常形態は認められなかった。

次に, 2 回目の交配においてもほぼ同様な結果が得ら れた。即ち，E 欠群では10匹中 7 匹に妊娠を認めたが， その多くは胎児吸収を起し，3 匹の親から合計 8 匹の胎 児を得たに過ぎなかった。そして，8 匹中 4 匹に肢指の 異常を認めた。これに対して，E入群では 7 匹中 7 匹に 妊娠を認め， 6 匹の親から合計 44 匹の胎児を得た。そし て，全胎児とも異常形態を認めなかった。

\section{5. 岡山大学医学部マウスコロニーにおける近交系マウ スの自然発生腫瘍について}

○藤田 甫, 有吉佐代子 (岡大・医)

〔目的〕岡山大学医学部マウスコロニーは，1958年発足 し, 現在13系統 (AKR, C58, C3H, RIII, Str.A, C57 BL, BALB/c, C3Hf/Bi, Db, Swiss, D103, CBA, R
F）の近交系マウスを繁殖飼育している。今回我々は, 1969年までにこれらマウスに生じた自然発生腫瘍を観察 し，その発生率を検討した。

〔方法】繁殖飼育中死亡し, 或は屠殺した動物を剖検 し, 諸臟器及び組織の一部を $20 \%$ フルマリン液に固定 し, パラフィン包埋標本作製の後, H. E 染色を行な い, 必要に応じ, 鍍銀その他の特殊染色を行なった。

〔成績】最も多くみられた腫瘍は, 乳癌と白血病であ った。その発生頻度は, 乳癌については, C3H (雌) : 経産, 76/105匹 (72\%), 処女, 77/86 (90), RIII （雌）：経産, 100/157 (64), 処女, $71 / 220$ (32), Str. A (雌)：経産, 73/84 (87), 処女, 11/61 (18), Swiss （雌）: 経産, 19/65（28）, 処女, 6/45（13）という成 績が得られ，白血病については，AKR：倠，54/93 (58), 雄, 26/80 (33), C58: 雌66/88 (75), 雄, 56/ 95 (59), Swiss : 雌, 7/110（6), 雄, $2 / 59$ （3）とい ら結果を得た。肝腺腫は, C $3 \mathrm{H}$ (雄) 飞多く, 20/180 (11), その他, 各系統のマウスに, 白血病, 肺腺腫, 細網肉腫, 線維肉腫などがごく少数認められた。

〔考察】螺良は, 繁殖を主目的とする飼育施設では正 しい自然発癌率を知ることは困難なことを指摘してい る。確かに我々のマウスコロニーに於いても, 実験に使 用される動物数が甚だ多く, 又, 癌年令に達するまでに 死亡した動物数が少なくないため, 発癌率の計算の仕方 には問題があった。被検動物数としては，6 力月以前に 発癌をみた $\mathrm{AKR}$ の 3 匹, C58 の 1 匹, $\mathrm{C} 3 \mathrm{H}$ (雌) の 3 匹, RIII (雌) の 1 匹以外は 6 力月以上生存し解剖し た動物及び一部，実験に使用した動物を選んだが，これ によって得た発癌率の数值が, 絶対的なものではないと しても，一応の目やすとして有意義なるのと考㝋る。

\section{[発言]}

江角吉造（日本シエーリング） 示された表には下垂 体腫演がなかったが，下垂体は検索されなかったか，そ れとも検索したが腫瘍をみなかったか。乳腺腫湯は動物 の場合良性, 悪性の組織学的診断基準が定めにくいが, ぞのようにして悪性とされたか。

藤田甫 (岡大・医) マウスでは頭蓋内腫瘍の報告 は少なく, 今回の報告では, 頭蓋内腫湯の存在について は検索がされていません。乳腺腫瘍については, 病理組 織学的検索により, 乳腺に生じた腫瘍で腺癌, 或は単純 癌の像を示したものを, 乳癌として報告しました。組織 学的に周囲組織への浸潤性增殖を示したものが多く, 又, 肺に転移をみたものが少数認められました。

小林孝好 (ヘキスト・ジャパン) 乳癌の転移部位及 び浸潤の程度はどのようであったか。飼料は何を使用し たか。

藤田 甫 (岡大・医) 乳癌の転移部位は, 肺に少数 
認められました。浸潤は, 周囲脂肪織内への浸潤が認め られました。飼料は，オリエンタル酵母工業 K.K. の実 験用及び繁殖用飼料を使用しました。

\section{20-M C-によるラットの皮ふ癌発生について}

○長瀬すみ, 佐藤 博, 長谷川明 (佐々木研)

〔目的〕 20-メチルコラントレン塗布による皮ふ癌 は, 普通マウスで作られ， ラットでは ACI (Takaya$\mathrm{ma}, \mathrm{S}: \mathrm{GANN}, 61,367)$ 以外, 出来にくいとされてい る。我々は, ラットの系統差により 20-MCに対する感 受性に差があるのではないかと考光, 数系のラットを用 い20-MCによる皮ふ癌の発生に関する実験をおこなっ た。

[方法] ACI, SD-JCL, Wistar-Imamichi, Buffalo, Wistar, Donryu の各系ラット 6 週令, ○を30頭ず つ電気ゴテで背部中央にヤケドさせ, 完全にヤケドを治 㾙せしめた後（ 4 週後）その部位に，0.3\%の 20-MC アセトン溶液 $1 \mathrm{ml}$ を週 2 回, 8 力月間塗布した。Donryuに関しては, ヤケドなしで，5力月技よ゙10力月塗 布した群，Wistar では，ヤケドなし 8 力月間塗布した 群についてもしらべた。出来た皮ふ癌に関しては組織学 的検索をおこない，併せて宿主の血液成分についても検 討した。

[結果] Buffalo 以外の各系統とも, 途中で事 故 死 (肺炎) するものが多く, 実験終了時までに約半数が死 亡した。 8 力月塗布実験群の最終成績（14力月）は, 皮 ふガン発生したもの ACI 12, SD-JCL 13, Wistar-Imamichi 14, Buffalo 24, Wistar 12, Wistar（ヤケド なし） 15, Donryu 11頭で, ぞの系統でも皮ふ癌を生 じ, 組織学的にも相違は認められなかった。しかし, 血 清成分の変化は ACI が最大で, Donryn が最小であり 同時期に扎いては， ACI が最も重症と思われた。

〔考察】 ラットでは皮ふ癌が作りにくいとされていた が，我々の特こなった実験結果では，用いた数系のラッ トの全系統に皮ふ癌の発生が認められた。只, マウスに 比し, 20-MC の塗布量が多いこと, 発癌までの期間の 長い事が異なっていた。ラットの長期実験では肺炎等に よる事故死が多く環境その他留意すべき問題が多くある 様に感じた。

\section{7. 前立腺癌 モデルとしての Shionogi carcinoma 115 につて}

○峰下鉘雄（塩野義・油日）, 山口健二 (塩野義・研)，松本圭央 (阪大・医)

〔目的】前立腺癌の特徴は(1)男性ホルモン依存性である ので，患者に去勢を施すことで有利に作用する，(2)女性
ホルモンの投与によって増殖は抑制される(3), 普通の抗 癌剤によっても増殖は抑制される。これらの特徴が Shionogi carcinoma 115 (SC115) にあることを述べ る。

〔成績及び考察〕 SC115 は既に第 4 回研究発表会に 於て報告の通り，DS系の雌マウスに自然に発生した腺 癌を同系の雄マウスのみに継代しているらちに(1)男性ホ ルモン依存性を獲得したものである。同系雄マウスに $\mathrm{S}$ C115を移植しても, 当該マウスに去勢を施す時はこの 腫瘍はまず増殖しない。(2)この腫痬の担癌雄マウスに Estrogen を投与する時は著明にその増殖を抑制する。 最近に Bruchovsky (1968), Wilson ら (1969) は男 性ホルモン依存性組織にはそれの基本的性格として Testosterone 5 a-Dihydrotesto-sterone ( $5 \alpha-\mathrm{DH}$ T) に転化する $5 \alpha$-Reductase が存在していること， および Estrogen 投与によって前立腺癌や前立腺肥大 症に有利に作用するのは, その細胞内の $5 \alpha$-DHT Receptor に Estrogen が cross affinity によって結合 するためであると説明して㧊る (Jungblut, Hughes, Goerlich, Gowers, Wagner). 山口ら (1971) は ${ }^{3} \mathrm{H}-$ Testosterone を SC115 担癌マウスに投与して Testosterone が $5 \alpha$-DHT に転化して前立腺执よび腫瘍組 織に特異的に存在するのを認め, Bruchovsky (1972) もSC115 DS 系此隹マウス移植してDHT を投与す る時は Testosterone に比して著明に増殖効果があるの でこの腫瘍は前立腺同様に DHT に直接的に作用を受 けるものとしている。

SC115の以上のような性格は初めに述べた前立腺癌の 特徴をそなえて拈り, そのモデルとしての条件を具備し ているものと考える。

\section{[発言]}

渡辺民朗（東北大） $5 \alpha$-reductase 酵素活性も Isotope を使用しての結果とパラレルですか。

峰下銕雄（塩野義・油日） 5a-reductase (testosterone の) 活性を測るのには testosterone が $5 \alpha$ dihydrotestosterone への転化の度合でみているので, この方法ではパラレルと言わざるを得ません。

\section{8. 腟垢像の変化からみた DSD, DDD 系マウスの Estradiol に対する反応性}

本間惣太（家衛試）

〔目的〕DＤ～系マウス子宮に打ける多発性囊胞形成 の発生機序の解析。

〔方法〕生後 $5 \sim 6$ 週令で卵巣除去したDSD, DDD 系マウスにエストラジオール $(0.025,0.05 \mu \mathrm{g})$ を皮下 注射して腟垢像の変化, および子宮粘膜上皮細胞の細胞 分裂数の変動を調べた。また, 卵巣除去した両系統マウ 
スに $0.05 \mu \mathrm{g}$ のエストラジオールを18日間連日皮下注射 して, 多発性囊胞形成がみられるかどらかを検討した。 〔成績〕胵垢に発情期像を誘起するには, 用いたエス トラジオールのいずれの量においても DSD は 4 回投与 を必要とし，DDD は 2 回投与で十分であった。子宮粘 膜上皮細胞の細胞分裂数では DSD が DDD ょりも有意 に低かった。エストラジオールの連続投与により，DS $\mathrm{D}$ では用いた 3 例とも典型的な多発性囊胞形成の発生が 認められたが， DDD（4例）ではその発生はみられな かった。

〔考察〕エストロジェンは DSD 系マウスの Endometrial cystic hyperplasia の発生に関与する要因の一 つであることが確認された。この場合， DSD 系マウス の子宮括よび胵のエストロジェンに対する反応性が低い といらことが重要な意味をもつことが示唆された。

[発言]

近藤恭司（名大・農） DSD は，他の系統と交雑実 験した場合など， $F_{1}$ がとりにくいなど，繁殖上变った 現象はみられないか。

本間忽太（家衛試） 藤田，大木らがこの問題につい て検討中で，近く発表されるものと思います。

49. マウスの乳仔下痢症に関する疫学的研究

○山本碩三，中川雅郎，田名網ふ2子， 佐味慎三, 木口一朗（予研），木下邦明 (船橋農場)

〔目的〕 マウスの乳仔下痢症の疫学を明らかにする目 的で, ddy および gpc コロニーに発生した自然例括よ び SPF マウスを用いた感染実験例について以下の観察 を行なった。

〔方法〕自然例では litter 別に生後0 21日まで每 日下痢の発症を観察し, 感染実験例については, 種々の 日令の SPF マウスに自然発症例の腸内容を経口投与し た後 3 週令まで毎日観察を続けた。本症の診断は下痢の 発症と下㢉便の色調ならびにその付着状況によって行な った。

〔成績〕自然例; 本症の発現率は $d d y, g p c$ と初 産に高いが， ddy では 3 産次より, gpc では 5 産次で $0 \%$ に低下した。また， litter size が5〜 6 以下では 発症率に低下がみられた。両マウスの初産発症率はddy では 29/82腹 (35.4\%), gpc では 105/162 腹 (64.8 \%)で gpc が ddy よりも本症に対して感受性が高いと 推定された。発症日令は両マウスとも 9 〜 10日を中心比 約 1 週間の巾を示し, 産次数, litter size とは関係な く一定であった。下麻の持続日数は 1 ～14日までさまざ まであるが，発症日令の若いものほど下㢉の持続は長い 傾向を示した。感染実験例 ; 初産の発症率はddy $75 \%$, gpc 100\%で両マウス間に差がみられた。しかし，自然 例に括けるよらな産次数の増加に伴ら発症率の低下は見 られず，4産次産仔でも高い発症率を示した。また，感 染時の生後日令が遅いほど潜伏期間は短かく，生後12日 以降に感染したものでは, 最早や発症しなかった。

[考察】自然例・感染実駼例共に注济同様な疫学的結 果が得られたが，雨者のもっとも大きな相違は，自然例 では初産に発症率が高く，産次がすすむにつれて低下す るのに対して, 感染実験例では産次数と発症率の間に差 の見られない点であった。この原因については, 感染に よる免疫の成立を考慮しながら今後検討する予定であ る。

[発言]

今井章浩（武田薬品・生物研） 1. 母獣の初産週令 との関係。2. 経口感染の方法, 特に, 乳剂のつくり 方。

山本碩三 (予研) 1. 乳仔下峲症の発症と, 早親の 週令との関係については検討していない。2. 感染材料 は乳剂ではなく, 症状のもっとも著明な時期の下㢉マウ スの盲腸内容を直接経口投与した。

牧野 進（塩野義・油日）乳仔下㢉症が 6 月頃多く みられるといった季節性はみられたか否か。

山本碩三（予研） 今回のわれわれの観察では，本症 の発症と季節との関連性は特にみられなかった。

\section{0. ラットにおける HVJ の疫学的調查}

○牧野 進, 瀬古彰司, 中尾博之, 三日月勝見, 亀井幸雄（塩野義・油日）

〔目的〕 ラット小集団の HVJ の疫学的調查を行ない 明確な流行期と流行閑期が観察された事を第 5 回研究発 表会で報告した。この成績はマウス大集団の HVJ の疫 学的様態と異なるものであった。そこで今回は HVJ の 流行様態に異なった型が観察される要因として集団の大 きさが関係するか否かを調べる事を目的とした。

〔方法】1968年より観察を行ってきた約 500匹収容の

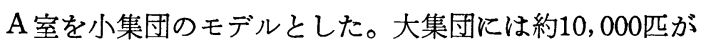
飼育されているラット生産育成場の中央の 1 室, C 室 （約 1,000匹収容）を選んだ。流行閑期のウイルスの動 向を知る目的で流行閑期に $\mathrm{A}$ 室のラットを約半数 700 $800 \mathrm{~m}$ 離れた $\mathrm{B}$ 室に隔離しその後の状態を検索した。ウ イルスの抗体は R. D. E 処理した血清中の HI 抗体で 調べた。ウイルスの分離は10\%肺乳剂を8 日令発育鶏卵 羊膜腔内に接種し $37^{\circ} \mathrm{C}, 3$ 日間培養後漿尿液の鶏血球 凝集性により判定した。

[成績〕（1）小集団では 2 年間で 3 回， $2 \sim 4$ 週持続 する流行をみとめた。流行間隔は約 $8 \sim 10$ 力月であっ た。流行時にのみウイルスが分離され又肺の肝様变化も 
観察された。(2) 大集団ではいずれの月でも抗体陰性の ラットと抗体陽性のラットの段階的な分布がみられた。 肺の肝様変化及びスナッフルラットが少数ではあるが匡 ぼ毎月みとめられた。（3） A 室の流行閑期に B 室に隔 離した集団ではウイルスの抗体がその後長期に亘って検 出されることはなかった。

[考察】 大集団の抗体分布がどの月も同じであった事 から大集団では小さな流行が常にどこかで执きていると 推察される。小集団ではウイルスの感染後短期間で集団 内の全ラットが抗体陽性となる為第 2 の感染が成立する 可能性が非常に少なくなり流行は一過性に経過してしま らと考えられる。HVJ の疫学的様態に異なった型が観 察される 1 つの要因として集団の大きさが関与している と思われる。

\section{[発言]}

前田良三（慶大・医） HVJ は一寸した温度でも発 症すると思うが， $5 \sim 6$ 月， $8 \sim 9$ 月は温度変化がはげ しいのと発症例の多いとの関係について, 参考になる点 について，教えて頂きたい。

牧野 進（塩野義・油日） ウイルスの流行は温度变 化等環境の変化により起きる可能性も考兄られる。しか し私はコロニ一内の抗体陽性ラットと陰性ラットの比率 の方がより流行の発生と関連深いのではないかと考兄て いる。

丸 守正 (塩野義・研) 同一ウイルスでマウスにつ いて $\mathrm{LD}_{50}$ の比較をすると 9 〜 12 月にかけて多くなるが 5〜6月にかけては抢ちる傾向がみとめられる。この傾 向は transmitted infection での recipient が示す 肺の lesion の強さにもみとめられた。HVJ をマウス 飞強制感染させて 3 力月後に transmitted infection を行らと $1 / 40$ からウイルスが分離できた。これ等マウ スの HI 価は128〜512を示したが， ウイルス分離陽性 例マウスはHI 価は8だった。同じウイルスでマウスに ついて， $\mathrm{LD}_{50}$ の比較をすると $9 \sim 12$ 月にかけて, 多く なるが 5 〜 月にかけては落ちる傾向が認められる。こ の傾向は transmitted infection での recipient が示 す肺の lesion の強さにも認められた。

岩井 浤 (実中研) 肺の肉眼变化を check したの は何週令のラットか?

牧野 進（塩野義・油日）特に日令を定めていな い。40〜250日令位までのラットを無選択に行った。

中川雅郎（予研） 1. 大, 小のコロニーサイズを教 えて下さい。2. 小コロニーではダストなどからのウイ ルス分離をされたことがありますか。3. 一度感染した 個体が再び感染することはないでしょうか。

牧野 進（塩野義・油日） 1. 小コロニーは adult 200匹，young 300匹の約 500 匹程度の大きさである。
大コロニーは約10,000匹が生産育成されている動物舎の 1 室のデーターで 1 部屋には約 1,000 匹が飼育されてい る。2. ダスト等からのウイルス分離を試みた事はな い。3. 再感染したかしないかはわからない。ただ自然 感染例で流行の前と後ではウイルスの HI 価の変動はみ とめられなかった事からたと感染しても肺炎をおこし たり，重篤な症状に陷る可能性は少ないと思う。

\section{HVJ 污染マウスコロニーにおけるウイルスの存続 様式}

○岩井 浤, 伊藤豊志雄, 山中順子, 石原保子（実中研）

あるマウスコロニー（生産規模約 6,000 匹／週）を HV $\mathrm{J}$ の侵入から約 2 年間にわたり補体結合反応により観察 し以下の成績を得た。

(1) HVJ 侵入時に離乳率が $92,3 \%$ から $40 \%$ に低下し, 抗体の出現とともに回復し, 以後異常は認められなかっ た。

(2)退役マウス（ 6 〜 8 力令）の抗体陽性率はたえず 90 100\%を示した。

(3)各週令に和ける抗体陽性率は, 週令が增すとともに 高くなり，8〜9週令ではほ注全例が陽性となった。ま た $5 \sim 7$ 週令マウスは肉眼的肺病变を示す頻度が高かっ た。

(4) HVJ フリ一環境に隔離飼育された HVJ 感染耐過 マウス由来の仔には移行抗体が証明され，そのまま隔離 維持すると HVJ 抗体は検出されなくなり, 污染環境に 出せば抗体は陽転した。

(5) $3 \sim 4$ 週令で HVJ フリ一環境に隔離飼育されたマ ウスを 6 〜週令で抗体検索する実験を 3 回行ったが， 2 回は抗体が証明されなかった。

以上の成績から，このマウスコロニーでは，毎週種親 候補としてとどまる 3 週令マウスが移行抗体消失後感受 性となり（主として $5 \sim 6$ 週前後），これが毎週くりか えされるため常時感受性マウスが存在することとなり， HVJ がこれらのマウスに感染, 繁殖し, コロニーに存 続するるのと考兄られた。ま，抗体陽性マウスのみの 繁殖集団を設定すれば HVJ フリーマウスを得る可能性 が示唆された。

\section{[発言]}

丸 守正（塩野義・研）抗体保有親マウスから生れ た suckling mouose の感染の時期について離乳後すぐ に感染するものもあるが, ほとんどが離乳後 $3 \sim 4 \mathrm{w} て ゙$ あり，この時期に肺には consolidation が認められ る。一方 $\mathrm{HI}$ 抗体の消長をみると離乳後すぐには 32 64 あるが，大多数が感染する $3 \sim 4 \mathrm{w}$ 後では，16以下だ った。 
中川雅郎 (予研) young mice で移行抗体が消失 し, 再び再感染する場合に, 肺病変は形成されますか。 岩井浤 (実中研) 形成される。このコロニーでは 6 週令前後のものに肺病変が多い。

\section{Mycoplasma pulmonis と HVJ のマウス肺炎 起炎性に関する研究}

○斉藤 学, 山本碩三, 武藤 健, 中山一栄, 佐味慎三, 中川雅郎 (予研)

〔目的〕 Mycoplasma pulmonis（以下 M. p) 执よ び HVJ のマウスに対する肺炎起炎性を知る目的で以下 の実験を行なった。

〔材料和よび方法】 Semi-conventional な環境（ケ 一ジ，床敷は滅菌，飼料，飲水は滅菌せず）で，3つの アイソレータ内にそれぞれ約100匹の種親よりなる dd系 $\mathrm{SPF}$ マウスの生産コロニーを作り，M.p および $\mathrm{HVJ}$ を単独または混合污染させた。そして，各アイソレータ より約30週間にわたって定期的にマウスを取り出し，剖 検によって肉眼的に肺炎の有無を調べると同時に，鼻 腔，気管，肺の培養によって M. p を検査し，HI テス トによって HVJ の感染を調べた。

〔成績拉よび考察〕M.p 単独污染コロニーでは，污染 後に生まれた仔を含めて，ほとんど例外なくすべての個 体が M. p に感染し，乙かも感染は長期にわたって持続 したが，肺炎の発現率は低く，全検査例数の $7.8 \%$ に止 まった。HVJ 污染コロニーでは，実験開始後 2 週以内 にすべての個体に HVJ の感染が成立し，感染初期には 高率（約90\%）に肺炎を認めたが，抗体の上昇と共に病 変は急速に回復した。また，これら感染マウスより生ま れた $\mathrm{F}_{1}$ 代あるいは $\mathrm{F}_{2}$ 代の仔には抗体の上昇が見られ ず，さらに HVJ 感染歴のない新しい SPF マウスをア イソレータ内に入れても肺炎の形成や抗体上昇がみられ なかったことより，感染マウスでは病変の回復と共にウ イルスも消失するものと推定された。 M. p と HVJ の 両者が同時に混合感染した場合は肺炎発現率が非常に高 く, 一般状態も極度に悪化して，多くの死亡例を認め た。しかも，一度形成された肺病変は長期にわたって持 続し，病変部より常に M. p が多数分離された。

[発言]

丸守正（塩野義・研）使用したウイルスの力価を 扣教え載きたい。即ち，ウイルスの継代歴 $\mathrm{EID}_{50}$ Mouse $\mathrm{LD}_{50}$ MouseID 50 について。

斎藤 学 (予研) マウス (gpc) 肺より chick embryo で分離したウイルスをその後 chick embryo で12 代継代して使用した。 $\mathrm{EID}_{50}, \mathrm{LD}_{50}, \mathrm{ID}_{50}$ は測定して いませんが，マウスの鼻腔を $120 \mathrm{ccA}$ のウイルス原液に 直接つけて吸い込ませたので，大量のウイルスが投与さ
れたすのと思います。

53. ウサギにおける気管支敗血症菌感染の疫学的調查研 究

○依田八治, 中山一栄, 遊佐智栄, 松本幸蔵, 渡辺幹男, 中川雅郎（予研）

〔目的〕各種実験動物に対する気管支敗血症菌の病原 性ならびに疫学を知るための一環として，ウサギに括け る本菌の感染を, 自然感染例括よび感染実験によって疫 学的な立場から検討した。

〔材料および方法】使用したウサギは市販の日本白色 種およびその雑種である。本症の診断は鼻，気管あるい は肺よりの菌分離によった。鼻から気管上部へかけての 菌検査にはマッコンキー培地を用い，気管下部ならびに 肺の培養には血液寒天を使用した。感染実験にはウサギ 由来の新鮮分離株を用い, 所定の菌数を鼻腔前庭に塗布 接種した。

〔成績〕 予研入荷時に怙ける市販ウサギの保菌率は, 季節に関係なく通常数\%であった。しかし，自家繁殖を 行なっている業者からの購入ウサギでは60\%の高率を示 した。数\%の保菌率を有するウサギを，すでに感染個体 のいるウサギ飼育室に収容すると陽性率は漸増し，3力 月後には $97 \%$ の個体が本菌に感染した。感染に要する菌 数を経鼻感染実験によって求めたところ，106 菌数で は $5 / 5,10^{4}$ では $3 / 6,10^{2}$ では1/6匹に感染が成立した。 自然感染例の $80 \%$ 強は10～15力月以上にわたって排菌を 続け，自然回復を示すものは稀であった。感染個体を剖 検すると, 鼻道, 鼻腔より高率に菌が検出され, 気管上 部，下部，肺の順に検出率は急激に低下した。また，肺 から菌が検出された個体でも肉眼的に肺炎はほとんど見 られなかった。1 $0^{6}$ 菌数を経鼻接種し, 感染の経過を追 ってみると, 菌は鼻道, 気管上部, 下部の順に侵入増殖 し，接種後10〜20日で肺に達したが，肺炎の形成はみら れなかった。その後, 菌は肺, 気管より漸次消失した が，鼻道，鼻腔からは長期にわたって検出された。

[発言]

丸守正（塩野義・研）気管支敗血症菌の分離期間 は長くてどれほどか。

依田八治（予研） 感染後10〜15力月間調べた範囲で は 9 割弱が排菌を続けますから大部分は少なくともこれ 以上の期間排菌すると考学られます。

\section{4. ウサギ Tyzzer 病の自然発生}

\section{○来原兄忠, 寺内 淳（日本メルク万有）}

〔目的〕実験使用のため購入したウサギが，下痢・採 食不良により瘦削し，使用出来ないものが多い。検疫中 に予後不良と判断し, 病理解剖を行なったものの多く 
は，コクシジウム症であったが，1972年 4 月に Tyzzer 病の自然発生例に遭遇した。非常に珍らしい症例と思い 報告する。

[方法]某動物商より購入せる日本白色家兔雄（入荷 時の体重 $2.3 \mathrm{~kg}$ ）を君亡直前に殺処分し，病理解剖に供 した。全身臟器を採集し $10 \%$ Formalin 溶液に固定,

Paraffin 切片を作製し, H-E 染色のほか Tyzzer 菌 （T. 菌）検出のため各種の特殊染色を施した。

[成績] 病理解剖所見は, 肝の小斑点壊死巣の多発, 心筋の壊死・石灰沈着と出血性壊死性盲腸炎であった。

組織学的所見は, 肝; 巣状性凝固壊死で, 壊死巣内に 多形核白血球が散在し, 壊死周囲には Heterophil が出 現した。壊死周囲の肝細胞内に T. 菌の寄生が極く少数 観察された。陳旧病巣では, 円形細胞の浸潤が強く, 石灰 沈着もみられた。心; 巣状性凝固壊死の多発があり, そ の壊死した心筋線維は石灰変性を呈していた。壊死周囲 には, Heterophil の反応がみられたが, 典型的な T.菌 の寄生は認められなかった。腸；回腸・盲腸・結腸に壊 死括よび T. 菌の寄生があり, 特に, 盲腸壁の壊死性変 化と水腫が強く, 多数の $\mathrm{T}$.菌 が上皮細胞・固有層・粘 膜筋板の各層に観察された。T.菌は, $0.5 \times 10 \mu$ 大の真 すぐな長桿菌で, Gram 陰性, Giemsa, PAS, Levaditi 扣よび Warthin-Starry 鍍銀法に陽性で, 諸家の検査 成績とほぼ同様であった。

な扔， T. 菌の分離を試みたが，不成功に終った。

[考察】 Tyzzer 病は, E. E. Tyzzer (1917) によ り，マウスの病気として発見され，最近ラットでの報告 が多くみられる。ウサギに扔ける Tyzzer病の自然発生 は, A. M. Allen, et al. (1965) および R. C. Cutlip, et al.（1971）によって観察されているが，我が国では 末だ報告されていない。

[発言]

白鳥耕也（資生堂・研） ウサギの Tyzzer 病の自 然発生例について, 購入したウサギの般死例を剖検検索 し, 心病変を主体とする Tyzzer 病を観察したので追 加報告を致します。

1971年 7 月 1 頭, 71 年 12 月 1 頭, ' 72 年 7 月 1 頭計 3 頭で整死時の月令は 3 力月令であった。臨床的には体重 増加の不良, 動作不活発等の症状のみられる例もあった が，余り症状を示さず急死した。剖検所見は胸腹水の著 明な増量がみられ, 心の肥大が著しく, 心筋に灰白色の広 範な壊死巣がみられた。肺はらっ血水腫がみられ, 肝は らっ血が強く, 溷濁腫脹がみられ, 灰白色の小壊死巣が はっきりとみとめられなかった。組織学的に心筋の変性 壊死が強く, 巣核球, 偽好酸球の浸潤, 石灰沈着, 線維 性増生がみられた。肝はらっ血が高度で小壊死巣がみら れた。心及び肝の渡銀標本で Tyzzer 菌をみとめた。
来原兄忠（日本メルク萬有） 完全な追加報告であり ましたので, 当方が解答する必要はないものと思いま す。しかし追加発言者の白鳥氏に, 腸の病変の有無を質 問しましたら，腸の検索はしておりませんとのことでし た。

\section{5. ウサギの趾踵部炎症に関する研究 I . 発生, 経過 について}

○野口午郎, 二木力夫, 内山智晴, 宇佐美正義, 佐藤忠夫, 高垣善男

(中外・綜合研)

らさぎが長期試験のために多数使用されるに及び種々 の疾病の統御の問題が注目されるようになっている。注 目されている疾病のひとつに足根部の炎症があげられる が，本症については詳細な検討が行なわれておらず，そ の予防措置も明らかでない。演者らは最近その発生に遭 遇したのを機会に $2 ， 3$ の検討を行なった。今回はその 発生と経過を中心に述べる。

発生群は約 3 力月令時に繁殖場より移し恒温・恒湿の 条件下で固型飼料 $(\mathrm{C}-5$, オリエンタル酵母 $\mathrm{KK}$ 製 $)$ ・水 を自由に与え，金属製網ケージ $(35 \mathrm{~cm} \times 50 \mathrm{~cm} \times 35 \mathrm{~cm})$ 内で飼育したものである。同群では 1 力月後（約 4 力月 令）より足根部に脱毛の認められるらさぎがあらわれ始 め, ついで局所の肥厚, 痂皮形成, 出血, 化膿が観察さ れた。病変は四肢いずれにもあらわれ，2 力所以上に及 ぶ例も見られた。病変の発現にともない体重は一般に減 少し, 重症例では著しかった。軽症の場合には減少した 例と，変化の認められなかった例があった。血液性状へ の影響も顕著であり, 赤血球数, 血色素量およびヘマト クリット值は減少し, 白血球数は増加した。なお, 白血 球数は 3 万を越す場合もあり, 病変の発現と同時に增加 し，好中球，とくに分葉核球が増加した。

組織学的には足根部局所では化膿巣（表皮～皮下織) が観察されており，そのほか局所リンパ節および脾が肥 大していた。重症例では肝・腎および脾にアミロイド変 性掞よびリンパ節の荒廃が見られるものもあった。

以上，らさぎの足根部の炎症について発生経過を括っ てその病変ならびにその発現にともなら影響を観察し た。本症については今後, 発生原因の追求および予防対 策などに関して検討を行なわねばならないと考える。

\section{[発言]}

三浦克洋 (家衛試) 家兔を長期間飼育し，同様の経 験をしているが，金属製ケージの床，とくに棒または金 綱などの構造と体重負荷との関係で足のららにこのょう な異常をきたするのと考光，竹板を渡したところ，若干 回復に向った経験がある。

野口午郎（中外綜・合研）演者らも床の構造との関 
係について検討していますが，無関係とはいえません。 しかしそれの及で発生を左右するとは考兄らません。そ のほかにも原因を求めねばならないと考光ています。 武藤 健 (予研) 足根部の傷害の発生原因につい て，何か技考学がありましたら拓伺い致したい。

高垣善男（中外・綜合研）体重の影響(給䬣量など) 飼育ケージの構造によって発生率に差があるようです。 これらのことが原因の一部と考兄られますが，今後いろ いろと検討する必要があります。

\section{6. ラットにおける Tyzzer 病の自然発生例について}

○武藤 健, 中川雅郎 (予研), 藤原公策 (東大・医科研)，平賀興吾（都衛研）

我国に猢汻るラットの Tyzzer 病の報告は高垣ら，山 田らの潜在感染例, 倉科らの繁殖コロニ一の自然発生例 の報告がある。これらの症例の病変は肝に局限してみら れているが，最近寺内らの心筋炎肝炎を主体とする自然 発生例が報告されている。我々は1972年 3 月某生産場よ り購入したラットに心腸肝病変を主体とする Tyzzer 病の発生をみとめ,さらに生産コロニ一の検索に执いて も本病を夕とめたので，その成績について報告する。 〔発生状況〕1972年 3 月に 4 週令 Wistar ラット500 頭を購入した。入荷後13〜27日間に下㢉, 腹部膨満, 動 作不活発，整死等の異常動物 47 頭を観察した。14頭を剖 検し心, 腸, 肝に病変をみとめた。さらに污染源を確か めるため生産コロニーの $7 \sim 8$ 週令ラット 35 頭（一部コ 一チゾン処置個体を含む)を剖検, 検索して11頭に Tyzzer 病変をみとめた。感染は生産場で行なわれていた。 〔病理学的所見】 心筋に不正斑状の变性壊死巣がみら れ, 組織学的に心筋線維の変性壊死が著明で, 単核細胞 の浸潤がみられ，一部に強い線維性の増生がみられた。 この病変は25例中18例にみられた。肝は混濁腫脹, 包膜 炎がみられ, 巣状壊死の及られた例は極めて少なかっ た。しかし組織学的に肝細胞の凝固壊死, 周囲に細胞浸 潤のみられる巣状壊死像がみとめられた。回腸は通常の 大きさの数倍の著しい拡張がみられた。粘膜の䋐毛は短 かく，固有層に細胞浸潤がみられた。筋層及び漿膜に筋 線維の变性, 水腫, 細胞浸潤等がみられた。肝及び心の 塗抹・組織標本に Tyzzer 菌をみとめた。

\section{〔血清学的検査〕}

抗原增幅法を用いて検査し、ラットTyzzer 病由来株 を抗原とし，16〜128 倍にわたる陽性例がみられた。マ ウス由来株では陰性であった。

\section{〔菌分離]}

試みたが成功しなかった。

以上の所見から今回の症例を Tyzzer 病と診断した。 従来, Tyzzer 病の診断に肝の巣状壊死像が注目されて
いるが，今回の症例は肝病変が軽度であった。今後ラッ トの Tyzzer 病の検索には肝と共に心及び腸病変につい て充分注意すべきであると考える。

\section{[発言]}

来原兄忠（日本メルク萬有）腸病変の組織切片で,

Tyzzer 菌体を観察しておられますか?。

武藤 健（予研）腸の普通染色標本では Tyzzer 菌 体をみとめて和りません。さらに鍍銀染色等を行なって 詳しく検討を加えたいと思います。

\section{Wistar 系ラット集団にみられた野鼠との交雑と思 われる一事故例について}

○山田淳三, 山崎友吉（放医研）

当所で生産している Wistar系ラット（近交系由来ク ローズドコロニー）に1971年 6 月 9 日分婏仔10匹（5： 5 ) のらち野鼠色の 1 個体が発見された。その個体は aguti 合で腹に小白斑があり, 発育は他の litter-mate に比べ著しく良かった。処置として 親及び仔を繁殖集 団からはずすとともに，変異の原因及び繁殖集団に乱け る分離の有無を調查した。

変異個体を同腹早 2 匹と交配したところ，次世代で albino 11 , aguti 14 , aguti hooded 10 , black 13 , black hooded 7 と分離し， C, A ,H の 3 locus K 分離が起っていることが確かめられた。早親を同じ令親 と交配した次産ではすべて albino で変異体は出現しな かった。次に Wistar 繁殖集団から任意に10匹（早 仓) を抽出し Tester (Moriyama) と交配し， $F_{1}$ 及 び逆し交配 (BC) 世代の毛色を調査した。 $F_{1}$ はすべて black hooded であり, Wistar への BC では albino : black hooded が $14: 24$, Tester への BC では black hooded : diluted hooded が74:66であったの で両 BC の分離比を 1：1 と推定した $\left(\chi^{2}=2.63,0.4\right.$ 6)。その結果 Wistar 及び Tester の遺伝子型をそれ ぞれ ccaaBBhh, CCaaBBhhxx ( $\mathrm{x}$ は劣性の bilute 因子であるが未確定のため $\mathrm{x}$ とした）と推定し，Wistar 集団内では分離していないと結論した。変異個体と 同腹早との仔の分離比から変異個体及び albino の遺伝 子型をそれぞれ CcAaBBHh，ccaaBBhh と仮定した 場合, 次世代の分離についての $\chi^{2}$ は 24.16 であった が, C locus のみが1：1から大きくはずれ $\left(\chi^{2}=19\right.$. 8) A, H locus では $1 ： 1$ を否定できなかったので，一 応この交配は hetero 個体と Wistar の交配であると 推定した。

この事故の原因としては, 以上の推定から突然变異, 転座（核型にも異常が認められなかった）等の遺伝的原 因によるものでなく，野鼠との交雑一そそれるケージ内 の Witsar 同志の交配及びケージの金網起しの野鼠と 
の 2 重交配の結果, 1 腹10匹のらち 1 匹の hetero 個体 が出現したものであろらと推定した。

[発言]

石橋正彦（麻布獣大） 発見された野鼠との交雑と思 われるすのを今後どのように使用して行くか。私も, 昭 和43年10月以来野鼠との交雑からすでに12代 sib-Mating を続けて維持している。今後これを発ガンあるいは 何らかの疾病モデルとして使いたいと考光ているので, ご指導を頂きたいし，さらに，誰方か使用して頂ける方 があれば，可能な限り分与したいと考えている。この系 統は毛色が Aguti でかなり綿毛を持つ例が出ている。

山田淳三 (放医研) 野鼠, 又は野鼠との交雑から得 られたものを維持して行くと, gene pool からしても新 たな形質が導入されることとなり，非常に有意義なこと と思う。今後是非色々な形質について調査して頂だき, 特性を発見されるよう㹉願いしたい。私の所でもこの後 代を維持し特性の調査をしたいと考えている。綿毛につ いては私の所では見られておりません。

前田甚作 (塩野義・研) 私はマウスの生産を始めた 頃, 野生のハツカネズミと交雑したものを飼育した経験 では行動が非常に荒っぽかったが今発表されたものはど 5? 。

山田淳三（放医研） 私も前に野鼠とWistar の交配 の経験がありますが， $\mathrm{F}_{2}, \mathrm{~F}_{3}$ 世代でもかなり荒っぽく 飼育に苦心したことがあります。今回の例ではその当時 のものよりは幾分ましのようでしたが，Wistar に比べ 非常に荒く, 現在その後代を飼育しております。まだ荒 らさは残って居ります。

\section{8. 市販 clean マウスの放射線関係実験への適用につ いて}

$$
\text { ○北爪雅之, 山田淳三, 土屋武彦（放医研） }
$$

〔目的〕市販されている Clear マウスの腸内細菌叢 は単純化されて括り, 此較的他の菌種が侵入, 定着し易 い状態にあると考えられる。しかも，放射線を照射する ことにより一層このことは助長される。

そこで, B S 施設でこれらの動物を照射した場合，動 物体への菌種の侵入, 定着の有無, およびその動物自体 が保有しているところの菌叢の中で放射線関係の実験, 研究を遂行していくらえに支障をきたすようなものの存 否を検討した。

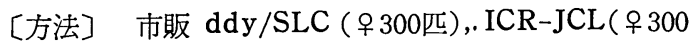
匹)の 2 系統のマウスを 6 週令で導入, 10 週令で ${ }^{137} \mathrm{CS}$ ・ $\gamma$-線の全身照射 $(550,600,650,700,750,800,1,000 R)$ をおこない，照射後30日間観察した。死亡個体はすべて その心血を培養し, 菌の有無および菌の同定を扣こなっ た。実験に使用した BS 施設は一般的な構造のものであ
り, マウスに与えた飼料はオートクレーブで滅菌し, 飲 水には $5 〜 7 \mathrm{ppm}$ 塩素を添加した。

〔成績】 照射後の死亡個体の心血からはPs. aeruginosa は 1 例 (1.5\%), Streptococcus (15.2\%), Staphylococcus (16.7\%), Proteus (9.1\%) が検出され たが早期死亡は認められず, 典型的な骨髄死の Pattern が得られ, dady/SLC, ICR-JCL 間では死亡率および 心血に出現した菌種についてはほとんど差が認められな かった。

また, 照射前括よび照射後の腸内細菌数を好気性培養 のみについておこなった結果, 腸内細菌, ブドウ球菌, レンサ球菌, 酵母・カビ類については照射前後の変動は みられなかった。

〔考察】 BS 施設で ddy/SLC, ICR-JCL の 2 系統 マウスを用いて ${ }^{137} \mathrm{CS} \cdot \boldsymbol{\gamma}$-線照射を抏こなった結果, こ れら市販 Clean マウスは放射線関係の実験に適用する ことができ，この BS 施設も十分使用できることが確認 された。

\section{[発言]}

中川雅郎（予研） 市販マウスを放医研の BS 施設に 入れてから何日で蛙使いになりましたか。その間に BS 施設内で Pseudomonas のマウス間の拡がりは見られ なかったでしょらか。

山田淳三（放医研）動物は $6 \mathrm{w}$ 令で入荷, 照射まで $4 \mathrm{w}$ 置きました。その間 2 回給水瓶残液を NAC 液体培 地で培養しましたが，Pseudomonas は1例も検出さ れませんでした。

\section{9. ラットの消化管内細菌に関する検索 1 . 発育期に おける細菌数の変化}

\author{
○餅田久利, 田内美代子, 炭萓鏡子, \\ 田中輝彦（エーザイ・生物研）
}

滅菌飼料給与によるWistar系ラットの生後 0 日令か ら 120 日令に至るまでの消化管内細菌叢について検索を 行った結果, Staphylococci は生後0日令で定着し, $10^{4 \sim 5} / \mathrm{g}$ の菌数を示した。Bacteroides は生後14日令で 最も遅く定着し, $10^{8 \sim 9} / \mathrm{g}$ の菌数を示した。Enteric-bacteria,, Streptococci, Clostridia, Lactobacilli は生後 3 日令で定着し, 特に Lactobacilli は $10^{9} / \mathrm{g}$ で 最も優位な構成菌種となった。又, 生後21日令以降の菌 数は, 通性嫌気性菌が $10^{4 \sim 5} / \mathrm{g}$, 微好気性菌, 偏性嫌気 性菌が108 9/g, で安定した。又, Bacillus は全く検出 されなかった。

生後28日令以降, 半数に非隇菌飼料を給与したとこ ろ，Bacillus が検出された。しかし，他の菌群につい ては飼料の相違による影響は認められなかった。検出さ れた Bacillus は Bacillus subtilis var. aterrimus, 
Bacillus licheniformis の 2 菌種で, 非滅菌飼料中か ら検出された菌種と一致した。更にこの Bacillus は滅 菌飼料給与で 2 日後に消失し, 非滅菌飼料給与で 1 日後 に検出された。又, フクシンを含有した飼料を給与した ところ，1 日後の霬便中にフクシンが検出され，給与を 中止した 2 日後には検出されなくなった。このことは, ラット消化管内で検出される Bacillus subtilis var, aterrimus, Bacillus licheniformis の 2 菌種は単なる 通過菌にすぎなく，定着しないことを示唆するものであ る。

\section{[発言]}

田中輝彦（エーザィ・生物研）私達がこの実験を 始めた基本的な姿勢は Barrier System 飼育の動物と Conventional の環境下での飼育された動物の生体全体 の比較をすることにあった。その内には, 滅菌飼料と非 滅菌飼料による生体成分の違いもあろうし, 成長性も寿 命も異ろらし, さらには腸内細菌叢の差異もあろらと考 えていた。今回，その一環として，まずは成長期の腸内 細菌叢の変動について報告したのではあるか，私達の意 図していることに執着すれば，本来は Normal Data の分野で報告をしたかった。

合田 朗 (北研) Hand feeding で育成されたの ではない様ですが, 親の腸内細菌叢との関係は如何でし ょうか。

餅田久利（エーザイ・生物研） 今回の検索は Barrier と Conventional な環境下での自然定着性の比較 を行い, 特に Barrier 内に拈いては, 定着性および菌 数の変動過程は親と同様の傾向があるものと考えられま す。授乳期に括ける，親と仔の菌叢については考慮にい れていませんでした。

勝俣是五郎（武田薬品・中央研）盲腸を特に選んだ 理由について、扮教えいただきたい。

餅田久利（エーザイ・生物研） 消化管各部位により 菌叢異なると考えられている。我々は，盲腸で検索を 進めることで, より多菌種の把握が可能と考えました。 又, 今後の追加検索では嫌気性菌を重視していきたいと 考えています。

前島一淑 (医科研) 1 . Clostridium 用培地の選 択性はどうか（すべて Clostridium とみてよいか）。

2. Flavobacterium, Streptococcus $\mathrm{N}$ の検索も, あるいは必要かと思らが, 検索の対象としなかった理由 があるか。

餅田久利（エーザイ生物研） 1 . 選択性について は，極めてよいものと考劣ます。2. 考慮にいれません でした。

\section{0. バリヤー内で人工哺育したラットの腸内菌叢の定着} について

○尾博之, 瀬古彰司, 牧野 進, 三日月勝見（塩野義・油日）

〔目的】微生物学的に外界と厳重に遮断された環境で 動物を飼育した場合, 定着した腸内菌叢は通常動物に比 べて単純な構成を示すとの報告がある。バリヤーシステ ムで生産された動物を用いての薬理実験が増加し, 疾病 による支障は解消された反面, 通常動物に見られるある 種の腸内菌叢が制禦され，そのため特に消化，吸収作用 に执いて通常動物と異なることが予測される。そこで先 ず腸内細菌叢を把握してその動物の生理学的特徴を明確 にする必要があると考光る。1971年 3 月にバリヤーシス テムが完成し，人工哺乳により基礎コロニーを育成した が，その経過に拉いて腸内菌敢の定着について検索し， 2,3 の成績を得たので報告する。

〔方法】実験に用いたラットは $\mathrm{S} \times \mathrm{W}$ の交雑系で子宮 切断術により導入し，人工乳は市販牛乳をべースに各種 ビタミンを添加しそれぞれ滅菌後調合し, 哺乳は 4 人の 男子が交替で $2 \sim 3$ 時間置きにカテーテルで行った。離 乳迄の期間は温湿度の制禦を容易にするため, 人間用の 保育器内で育成したが, 離乳後は飼育室へ移した。腸内 菌叢は 5 種の分離培地を用いて数回検索し, 乳酸桿菌, 酵母, 腸内細菌, 連鎖球菌, ブドウ球菌, 芽胞形成菌に ついて行い, 自然環境下で分娩したラットの菌叢と比較 した。

〔成績〕バリヤー内ラットの腸内菌叢の定着は, (1)ブ ドウ球菌, 酵母, 腸内細菌は生後 9 日令で既に定着を認 めたが，乳酸桿菌と連鎖球菌の定着は遅く生後93日令で 初めて認めた。(2)芽胞形成菌は生後93日令でも認めず, 1 年を経過した現在でもまだ認めていない。(3)定着した 殆んどの菌叢は菌数において大差はなかった。

[考察]バリヤー内で育成したラットの盲腸が通常動 物より大きいことが明らかになったが，その面でも腸内 菌叢の関与が考学られ，今回検索した以外の菌群につい ても検討することが必要であると思われる。

[発言]

松原孝雄 Barrier 内で飼育していく場合, 慨の滅菌 方法はどのようにしているのか。

中尾博之 (塩野義・油日) 私共の所では $121^{\circ} \mathrm{C} 5$ 分 間の高圧蒸気滅菌によりバリヤ一内へ搬入し給与してい ます。この 5 分間の時間設定に当っては, 以前に TGC 培地を用いて菌発育のない最少の滅菌時間を検討し 5 分 間で可能であると云う結果を得て現在に至っています。

中川雅郎 (予研) Barrier 内で定着したラットの flora と open system で飼っているラットの flora 
を菌の genus から見ると90日位で同じょうになる data を出して抢られますが, 污染源が open system では rat to rat でしょらが, barrier では man to rat で はないのでしょらか。そうすると, むっと詳細に調べれ ば両者は相当違っているのではないでしょらか。

中尾博之(塩野義・油日) バリヤーでは確かに人間 の影響が大きいと思われますし，オープンでも動物相互 の影響が考えられますが，今回の実験に执いては定着し た腸内菌叢が間由来の菌かどうかの確証はつかんで括 りません。定着した菌叢は菌数的には同じでも種につい て詳しく調らべれば何か差はあると考えています。

岩井 浤 (実中研) 菌そら形成過程で, 大腸菌々数 が $10^{9}$ レベルに達した後 $10^{7}$ 以下に減少する現象がある。 示された成績では, barrier と conventional room に おいては大腸菌々数の減少時期にずれがあるが, その理 由は何と考学るか，

中尾博之（塩野義・油日） バリヤーでは生後初期に 先行定着した 3 種の菌（ブドウ球菌, 腸内細菌, 醅母) の状態が長期間つづき, 他の菌の影響がないうちに減 少, 安定したものと考えられるが, 一方オープンでは既 に菌叢を形成した母獣が授乳したり，また離乳後末滅菌 飼料を摄取させたことなどの影響があるがやはり微生物 制御の面で大きく異なる点が注目される。

今泉清（予研） あなたの演題は疾病と異常の区分 に入っていますが腸内菌叢は疾病ですか，異常ですか。

中尾博之（塩野義・油日）私が特に希望した区分で はなかったよらです。腸内細菌叢の検索は疾病や異常の 分野ではなく正常細菌叢についてはむしろノーマルデー ターだと考えています。

\section{1. 最近 3 年間における市販実験用動物（主としてマウ ス・ラット）の寄生虫検查成績}

○田中英文, 藤波不二雄, 大島 慧 （田辺製薬・生物研）

〔目的】市販実験用動物の寄生虫污染の実態の把握。 [方法】各動物共到着後 2 日以内に内部寄生虫は検便 法及び剖検法により, 外部寄生虫は, モルモットはセロ ファンテープ法, 他は実体顕微鏡による直接鏡検を行な った。

[成績】マウス：普通動物 7 群1220頭よりダニ 4 種類 と条虫, 線虫各 6 種類, 原虫 6 種類が検出された。親が バリアーシステム (以下 BS ) 由来の 2 群1349頭からは ダニ類 1 種, 条虫 1 種, 線虫 3 種, 原虫 4 種類が検出さ れた。BS 2 群159頭からはダ二は認められず, 蟯虫と原 虫が 3 種類 $1 \sim 2$ 例に検出された。ラット：普通動物 6 群 625 頭よりダニ 3 種, シラミ 1 種, 条虫, 線虫各 3 種 類, 原虫は 6 種類検出された。親が BSの 3 群405頭には
外部寄生虫は認められず内部寄生虫は条虫, 線虫各 2 種 類, 原虫 5 種類が検出された。BS 2 群276頭にはダ二類 の寄生はなかったが蟯虫と原虫（トリコモナス）が少数 検出された。モルモット： 5 群 880 頭からダニとシラミ が共に 1 種類, コクシジウムが約半数に検出された。ウ サギ： 5 群 216 羽に, コクシジウムが高率に認められ た。肝型より腸型が多く検出された。その他に豆状霊虫 が数例認められた。

[考察】各寄生虫の濃厚感染が認められたものはいず れも普通動物で, しかも季節消長等はなく, 年間を通し て高率に検出され, しか子污染度の指標之なる帯状囊虫 や縮小条虫がマウス, ラット共に検出された。親を B S 由来にすればその効果は顕著でダニ類はほとんど認めら れなかった。しかし，一部の群に飼育管理の杜撰を思わ せる帯状囊虫や膀胱内に寄生する線虫が散発的に検出さ れた。血清診断により病原微生物 free という BS のマ ウス, ラットに蟯虫と数種の原虫が検出されたが, たと 病原性はないにせよ, 寄生虫についても free である 事が望ましい。

\section{2. モルモットにおけるコクシジウム感染による原虫相 の変化}

武藤 健, 杉崎正雄 (予研), ○白鳥耕也（資生堂・研）

モルモットに拈ける大腸内原虫相がコクシジウム（以 下コ）感染によって，いかなる影響を受けるか自然扰よ び実験コ感染例について検討した。

大腸内の原虫については Eimeria caviae (以下E) のオオシスト, Balantidium caviae (以下 B) 及び Trichomonas caviae (以下T) の栄養型に限定して, 盲腸及び結腸内容物を MHS (Methylgreen+Formalin 水十食塩）で固定，50 60\%のGlycerinで稀釈し， Fuchs-Rosenthal 計算板を用いて原虫の種類を判別し 定量的に計数を行なった。

1). 対照例のコ陰性モルモットの原虫相及び数は盲腸内 B $1 \times 10^{5} / \mathrm{g}$, T $2 \times 10^{6} / \mathrm{g}$ であり, 結腸内 B $4 \times 10^{4} / \mathrm{g}$, T $3 \times 10^{5} / \mathrm{g}$ であった。自然発生コ症の原虫相及び数は 盲晹内 $\mathrm{E} 8 \times 10^{5} / \mathrm{g}, \mathrm{B} 0 / \mathrm{g}, \mathrm{T} 3 \times 10^{5} / \mathrm{g}$ であり, 結 腸内 E $4 \times 10^{6} / \mathrm{g}, \mathrm{B} 0 / \mathrm{g}, \mathrm{T} 2 \times 10^{6} / \mathrm{g}$ であった。大 腸内 B はコ感染によって著しい影響を受けて消失がみ られた。2). 自然発生コ症の成績を確かめるために, E のオオシストを経口感染させた実験的コ症の大腸内原虫 を経時的に検索した。10日までは殁んど变化がみられず 対照例と同様であったが，Eのオオシストが大腸内に排 泄される時期（10１5日） には E の増数と共に B 数の 減少が急激にみられ，下沜発生時（15〜17日）には $\mathrm{E}$ 数の著しい增加によって自然コ症と同様に B の消失む。 
みられた。コ感染による大腸内原虫相の変化が確かめら れた。3).コ污染コロニーモルモットについてす検査し た。原虫相の変化はみられなかったが, コ陰性コロニー に比べて B 及び $\mathrm{T}$ 数の減少らがみれた。さらに $\mathrm{E}$ の検 出有無により分けてみると, 陽性群は陰性群に比べB及 び T 数の減少がみられた。

コ感染によって引き起こされる大腸内原虫相の変化 は，あたかも Bと Eとの間に競合する様な現象がみられ た。しかし, 我々はモルモットの原因不明の下痢症例で $\mathrm{B}$ の消失, $\mathrm{T}$ の減数・消失を経験しているのでさによる 特異的な変化とは推察され得なかった。むしろ大腸内 B の消失はコ感染を含めて下痢症発現との間に密接な関係 が存在しているものと考える。

\section{実 験手技}

\section{3. マウス, ラットの屠殺法についての一考案}

○谷口芳信（日本クレア）, 高橋 弘 (実中研)

〔目的〕動物を安楽死させ, 屠体の処理も容易である 屠殺の方法を知ることを目的とし，ドライアイスを使用 した方法を試みた。

[方法] 1. 従来の方法のひとつとしてクロロフォル ムによる方法を用い, ドライアイスによる方法と対比さ せて, 薬剂の使用量と致死時間との関係, 動物が死に至 るまでの経過を観察した。

2. ドライアイス法の場合の動物の体温, 容器内温 度, 容器内酸素量の変化について観察した。

3.ドライアイス法がマウス，ラットからウサギまで 使用できるような容器を考案した。

〔成績】 1.ドライアイスの場合, 動物は全く乱れる ことなく死に至る。致死時間は個体によってばらばら で，1群を10匹として，全例が死亡するまでの所要時間 はマウスの場合, 2 分 30 秒から11分を要した。ラットの 場合は，それよりやや延長する傾向がみられた。これに 対してクロロフォルムの場合は, 注入直後, 狂乱的に暴 れまわり殆んぞ全例が同時に死亡した。その所要時間 は, マウスでは 2 分以内, ラットでは 3 分以内であっ た。なお，死体の処理はドライアイス法によって屠殺し た方が，容易であった。

2. 動物が死亡するまでの間には, 容器内の温度はや やや上昇の傾向を示した。動物の体温は屠殺の直前から 直後までの間で約 $1^{\circ} \mathrm{C}$ 低下していた。容器内の酸素は 著明に減少して扣り, 炭酸ガスの急激な増加が示唆され た。

3.上述の観察成績からドライアイス法は安楽死と死
体処理が容易と云ら目的に叶らことを知った。そこで, ドライアイス法による屠殺の容器を考案した。この容器 は，マウス，ラット，ウサギまでに使用できる。フタが 透明であるので, 動物の死亡は肉眼で確認でき, 死体は 内装したビニール袋のままで処分できる利点がある。

\section{[発言]}

奥木 実（都老人研） ウサギのと殺の場合はいかが ですか。

谷口芳信（日本クレア） ウサギについても実験して みましたが，マウス・ラットの場合と同様，乱れること なく安楽死しました。

\section{4. 小動物における採血方法の検討 第二報，尾静脈採 血法}

○矢島隆二, 後藤鋼星，水上浩司 (ヘキスト・ジャパン)

〔目的〕 ラット，マウスを用いて薬物の長期毒性試験 を行なう場合その中間検査として血液学的検査を行なら 必要がある。この場合薬物の影響を明らかにするために その採血方法はできるだけ動物に侵襲を与えず，又，連 続採血が可能な方法を選ぶ必要がある。

[方法]我々は小動物での採血時の影響を血液学的性 状変動を主標として種々の方法について検討を行なって 扣り，昨年報告した舌下静脈採血時に执ける影響に引き 続き今回は, Schneider の尾静脈採血法 (Hoppe-Seylers, Z, 283, 112, 1948) について雌雄 8 週令の SDJCL ラットを用いて検討した。この方法はラットを市 販の固定台に固定し, ラットの尾部を酒精綿, ガーゼを 用い血管を怒張せしめた後, カミソリにて尾静脈を切断 しゴム栓とビニール管を利用した器具とアスピレーター で減圧下に吸引採血する方法である。

〔成績〕血液学的検查は, 抗凝固剂 EDTA-2K 処理 試験管に採取した血液を使用した。採血の体重に及ぼす 影響は 1 日 5 回連続採血を行なってもほとんど見られな かった。赤血球数（TOA-Micvocell counter）へマ トクリット值（毛細管法）へモグロビン量 (Cyanmethemoglobin法) は2 日後では軽度の減少がみられる が，3 日後にはその採血の影響から回復した。白血球数 (TOA-Microcell, counter) では著明な変動はみら れず，血小板数（TOA-Microcell counter）は雌雄 共に採血 3 日後まで増加傾向がみられるが 7 日後にはほ とんど回復していた。網状赤血球数 (Brilliant cresy1 blue 染色）では変動がはなはだしく一定傾向の影響 を明らかにすることはできなかった。尚, 白血球像 （Wright-Giemsa染色）については明らかな採血の影 響はみられなかった。

[考察） 以上の様な採血時の影響は採血量が0.6〜0.8 
$\mathrm{ml}$ の範囲では同様の傾向を示したが動物への侵襲を最 小限とするためには $0.6 \sim 0.8 \mathrm{ml}$ の採血がラットの場合 適当と考えられる。

\section{5. シロネズミの新しい固定法と頸静脈連続採血法}

○金武朝春，瀬井康雄，荒川清二 （湧永薬品・中研）

表題の目的のために簡易な固定器を考案した。馬の口 につける「はみ」の原理を応用し，二個の口金の一つで 上顎門歯の直下を通して固定し，下顎をもう一つの口金 を上下に動かして固定を確実にする。四肢は市販の合成 樹脂製吸盤（帽子かけなどに用いる）の掛釘に相当する 蓋をはずして肢を入れ蓋をして固定する。頸静脈採血の ために側頸部をアルコール綿で清拭し，鎖骨に沿って外 側に指先をずらして行くと頸静脈が柔かく触れる。頸静 脈は膨隆してアルコール綿で清拭すると皮覤の上から黒 くみえる。但し肥って脂肪のついたものでは黒く見えな いこともある。この時は柔かい感触だけで触知する。そ こをピンセットでつまみ上げ，できるだけ皮下の血管を 切らぬ上ら固定板と平行に水平に鋏を入れて皮膚を楕円 形に切る。その大さは目的に応じてきめる。すなわち 1 〜2 回の採血ならば切口を小さくし, 連続採血の場合は 広く切除する。切口には消毒薬又は抗生物質を塗る。2 本のピンセットで皮下の脂肪組織を分離すると胸骨乳突 筋と鎖骨乳突筋と鎖骨に囲まれた部に扇形をした頸動脈 が露出してくる。頸静脈は管壁が動脈ほど弾性がなく薄 くて破れ易く，周辺に小血管が多いから切断しないよう 注意する。頸静脈に注射針を入れるにはすず「筋に針を 入れて」静かに頸静脈に刺し入れると針先が固定されて 血液が採れ易い。頸静脈飞針が入ると注射器をるつ指先 の抵抗感が弱くなる。それと同時に吸引する。固定した まま連続採血する場合には径 $5 \mathrm{~mm}$ のビニール管にへパ リンを通し,静脈に插込み血管の上から管を糸で固定し， コッヘルで管口を押え，要に応じて採血するのも一法で ある。本法で例えば Alloxan を静脈に注射して一過性 血糖上昇と慢性糖尿病を起させ経時的血糖值が個体によ る大きなバラッキなしに観察できた。本法は麻酔を要せ ず，簡易に随意量連続採血でき，動脈血採血もこれに準 じて行える点便利であると思われる。

\section{[発言]}

坂口 孝(ヘキスト・ジャパン） 1 . 採血量はどの 位でしょうか。2. 正常ラットで連続採血時の血糖値の 変動はいかがでしょらか。3，採血時の注射針の太さは どの位ですか。

荒川清二 (湧永薬品・中研) 1 . 採血量は必要に応 じて相当量とる。血糖の場合は $0.1 \mathrm{ml}$ で充分であるが， 赤血球, 白血球, ヘマトクリット, 血色素量を二個所で
盲目検相をした場合では $1.0 \mathrm{ml}$ とったことすあるが， 1 週間後の影響はあまりみとめられなかった。2. 当然 しらべるべき基礎試験と思うがまだ行っていない。

3. 1/3-1/4 で充分である。

\section{6. 腟外見所見を利用した妊娠ラットの確保，スメア法 と比較した交配率と作業効率}

○田中光夫, 児玉直己, 江角吉造 （日本シェーリング・研）

$7 ， 9 ， 11 ， 13 ， 15 ， 17 ， 19$ 週令の JCL・SD系末経 産ラットを20匹ずつ用い，恒温恒湿下で 1 匹ずつ飼育し 毎日一定時間に検索した成績を比較した。発情前期を示 したものを交配に用いたが，前期の外見所見は，スメア 法と比較し，腔口ゆるやかに開口，腔孔壁膨隆，粘膜は 赤ピンク時に若干白色調で乾燥光沢を有するものとし た。スメア法で前期を示した動物中，外見法でも前期を 示した動物の割合は, 7 〜3週令で $60 \%$ 以上であるが, 15 週令以降は漸減を示した。この事は前期の動物でも外見 上前述の所見を示さぬものがあり，その割合は高令で増 加する事を示している。各週令のラットを毎日両検査法 で調べ前期を示した動物を交配に用い，交配の成立した ものを除く方法で $80 \%$ ものが交配し終るまでの交配起 用率，即ち延べ検査動物数に対する前期を示した動物の 延べ数の率を比較した。いずれの週令に於てもスメア法 が高い值を示すが13週令を除いてその差は大きくなく， 一般に両検査法とも 7 週令で約 $25 \%$ 示した後, 週令と ともに減少傾向がみられた。使用した動物の $80 \%$ が妊娠 するまでの期間を比較すると，スメア法が短く，また週 令の若いもの程短くなっているが，開始時で11週令迄は 両法の差は少く，ともに 2 週間以内である。19週令のも のではスメア法で 3 週，外見法で 5 週を要した。 $80 \%$ 交 配成立に要する検査回数は, 11 週令迄 7 ～10回を要し両 法の差は大きくないが，その後は回数が増加するととも 飞差も大となった。1 匹当りの平均検查時間は，外見法 で20秒であって，スメア法の 1 分 56 秒の約 $1 / 6$ ，総時間 でも11週令迄はスメア法の約 $1 / 4$ であった。交配成立率 は，両法間に差は少く，17週令迄は週令による差も少な かった。以上妊娠ラットを効率よく確保する目的でスメ 了法之胵外見法を比較した結果， 7 ～13週令では，胵外 見法によっても充分その目的が達せられるだけでなく， 作業時間上からはより秀れていることが知られた。

\section{[発言]}

中野健司（予研） 発情前期の腔外見所見は，習熟し ない者でも他の発情期，終期と区別が明確につきますで しょうか。熟練した者でないと区別できないということ はないでしょうか?。

田中充夫（日本シエーリング・研） 発情前期と間期 
は一番明瞭に区別がつきますが発情期や発情後期とも充 分区別がつきます。私達の実験室で交配の企業をしてい る者は充分性周期を外見法で区別出来る能力をもってい ます。習得する事は別に困難ではなく, 私達と一緒にや っていただけば数日間で習得出来ます。

江角吉造（日本シエーリング・研）外見法では 100 \%前期を当てる事は出来ないが60\%位はカバーできる。 それでも作業時間等を考えれば充分目的にかなっている といら事を申し上げたい。

谷岡功邦 (実中研) ラットの交配の経験から, スメ 了観察により前期の動物を交配させたときよりも休止期 または後期より同居させて括いた方が交尾率が高いよう に思われた。またラットの交尾は, 前期の日以外に発情 期（III期）の日の夜にも成立することがあり，この場合 正常に妊娠する。

\section{7. ラットのヒフ移植試験法の比較検討}

○前田甚作，豊島久美子，原田喜男 (塩野義・研)

我々は近交系 Wistar ラット及び近交系 SD ラット の生産維持と癌移植などの感受性を知るために, その系 統ラットの均一度を検定するための一法として, 皮膚移 植試験を行っている。

移植の方法は, Billingham の背部同所性交換移植 と, Festing 等の方法による尾部同所性交換移植の二 法で，それについて比較検討を加えたので概要について 報告する。

背部の場合は約15～20mm 角に皮膚全層を剝皮して， 判定に便利なように移植片を逆方向に定着する。固定は ミヘル針, アロンアルファ，糸による縫合又はそれらの 併用を試みたが，何れも一長一短がある，これら縫合材 は自然脱落を待った。此の手技で最もむづかしいのは, 出血を極力少なく肉様膜を損傷せずに移植片を切り剝が すことと，固定の際に移植片を損傷しないことである。

尾部の場合は約 $10 \sim 15 \mathrm{~mm} \times 5 \mathrm{~mm}$ の長方形に移植片 を切り剝がして逆方向に定着する。固定は絆創高, グラ スカバー，アロンアルファなど用いたが絆創裔は最も優 れた成績を示した。絆創高の除去は20時間前後に行う。

判定についての観察期間を一応90日としているけれど も近交維持のものは終生観察である。

90日生着のものでも, その後いわゆる chronic rejection 症状で脱毛現象を示すものがある。

皮膚移植の二法を比較して, 尾部移植の優れた点を挙

げると次の通りである。

動物に与える苦痛が少ないこと。

手技が簡単である。

固定法が簡単で短時間にできる。
接着に要する時間が 6 〜20の短時間でよい。 手術後の飼育は多数飼育でよい。 成功率が高く95〜100\%である(対70\%前後)。

\section{8. ラットの甲状腺機能検查のための Triosorb Test.}

○樽本保男, 斎藤修司, 仲沢政雄 （大正製薬）

従来, ラットの甲状腺機能検查方法として主として行 なわれて来た ${ }^{131}$ I 甲状腺摂取率, 血清 PBI 量の測定 等は操作が煩雑で実験動物での routine work に適さ ない事が多い。最近, ${ }^{131}$ I-triiodothyronine resin sponge 撕取率 (別名Triosorb Test) と呼ばれる新し い検査法が開発され，臨床面での有用性が広く認められ るようになった。演者らはこの Triosorb Test を Trypan blue, Methylthrouracil, Thyroxine を処 置したラットに応用して, 他方法（ ${ }^{131}$ I 甲状腺摄取率, 血清 PBI, 甲状腺/血清ヨーソ比, 甲状腺重量) と比較 し, この方法が小動物の甲状腺機能検查法として充分利 用でさることを認めた。

Triosorb Test 法は, 試験管中にとった血清に ${ }^{131}$ ITriiodothyronine を加え, 更に resin sponge を加 光て管中の総放射能を測定して括き (1st Count)， 1 時間のインキベート終了後, 血清を除去し, sponge 内 に残溜した放射能を測定して (2nd Count) 2nd Count $/$ lst Count の割合から摃取率を求める方法で, 機 能六進症では高值を, 低下症では低值を示す。

Trypan blue, Methylthrouracil では Triosorb 值, 血清 PBI 值とも低下し, Thyroxine では兩者と も増加して，いずれも平行した相関性を示した。

Triosorb Test 法は血清 PBI 法や, ${ }^{131}$ I- 甲状腺掑 取率法よりも操作が極めて簡単で, Sample の保存が可 能であり，また少量の Sample で動物を殺さずに検查 できるなど多くの長所を有し，thyroxine 処置等の特 殊な場合をのぞき，甲状腺機能を簡便に測定出来る方法 として有用であると思われる。

[発言]

$$
\text { 施設 }
$$

69. 実験動物飼育施設の環境調査, II . F 生育場

○高橋 弘, 米山敏子, 佐藤悦子, 今井都泰 (実中研), 谷口芳信, 田口福志（日本クレ 了), 嶋本洋二 (日東理科工業)

〔目的〕実験動物飼育施設の環境統御に関する基礎資 料を得る目的で，本調查を括こなった。

〔方法】静岡県富士郡に SPF ラットの生産を目的と 
して新設された施設（軽量鉄骨ブロック造り，平剭 420 $\left.\mathrm{m}^{2}\right)$ の建築完成時に抢ける温度・湿度の分布と経時変 化, 外気温湿度との関連について調査した。

測定方法は, 1. 同施設の飼育室内 $\left(150 \mathrm{~m}^{2}\right)$ 飞 527 点（1平面につき 176 点とし，床面より $40,90,150 \mathrm{~cm}$ 高の 3 面をとる）を定め, 各点に㨟ける温・湿度を測定 した。2 . 飼育室内中央部の 3 点と外気取入口および排 気口（2 力所）の温・湿度の経時変化を測定した。

測定に使用した機器は，1。アスマン式通風乾湿計,

2. 横川電気製打点式温湿度検出記録器である。

[結果〕 1. 飼育室内 527 点の測定の結果, 温度分布 の中央值は $20.8^{\circ} \mathrm{C}$ (150 $\mathrm{cm}$ 高), 湿度分布の中央值は50 $\%(150 \mathrm{~cm}$ 高) であった。

2 . 分布の最高と最低について, 中間 $90 \%$ の範囲をと って評価する試みを招こなったところ, 温度は $3.2^{\circ} \mathrm{C}$, 湿度は $16 \%$ の゙らつきがあった。

3 . 今回の調查期間（1972年 2 月）中の外気は温度 0 $\sim 5^{\circ} \mathrm{C}$, 湿度30 90\%であった。飼育室内温湿度の経 時変化には外気条件と関連するような動きは認められな かった。

[考察】実験動物飼育施設の 1 例について, 飼育室内 の温湿度分布拉よび外気温湿度条件との関連に扣ける経 時変化についての資料を得ることができた。

この種の施設は個々に独自の条件があるために, 環境 統御に関しても一般性（共通性）を求めることは難かし い。したがって，出来るだけ多くの施設について調査す ること，および長期間にわたる調査を扣こならことによ り，目的達成のための手がかりとしたい。

\section{[発言]}

河合清之（労衛研） 1. アネモ吹出し, 片側流し出 乙型式下で得られた結果を，層流方式へ向っている現在 の思想傾向と対比して，どのように和考兵になっておら れますか?。2. 環境統御の目標位置を，室内におくか ケーヂ内におくか，御意見があれば伺いたいと思いま す。

山内忠平 (実中研) 1. 層流方式についても同様な 精密測定を行って比較してみなくては何ともいえない。 2. 環境統御の目標位置は一応飼育室に扣くが，ケージ 内の実態についても充分認識して実施する必要があると 考光ます。

\section{0. 実験動物飼育施設の環境調查，III. I 生育場}

○山内忠平, 平山三船 (実中研), 谷口芳信（日本クレア）

実験動物飼育施設の妥当な環境制御の基盤を確立する とともに, 簡易で標準的な測定方法をつくるために, 飼 育施設の環境調査を行っている。この報告では, SPF
ラットの生産を目的としてつくられた施設の完成直後に 扣ける温度・湿度・風速と, 動物を収容するようになっ てからの温度・湿度について報告する。

測定は飼育室の床上 $0.5 \mathrm{~m}, 1 \mathrm{~m}, 1.5 \mathrm{~m}$ 高さに和い て，それぞれ 150点で行った。また，動物を収容したの ちは部屋の中央においた自記温湿度計で経時的に測定し た。

温度は平面的には $2 \sim 3^{\circ} \mathrm{C}$ の差があるが, 高さ別の 中央值は床上 $0.5 \mathrm{~m}$ で $20.8^{\circ} \mathrm{C}, 1 \mathrm{~m}$ で $21.5^{\circ} \mathrm{C}, 1.5 \mathrm{~m} て ゙$ $22.1^{\circ} \mathrm{C}$ と床面の方が低く, $1 \mathrm{~m}$ 高くなる毎に $1.3^{\circ} \mathrm{C}$ 高 くなっていた。しかし, 動物を収容後には $1 \mathrm{~m}$ 毎に約 0 . $3^{\circ} \mathrm{C}$ 高くなっていた。動物収容後の経日的測定では 21.5 $\sim 24.5^{\circ} \mathrm{C}$ の範囲にほぼ保たれていた。

湿度は平面的には $7 \sim 10 \%$ 差があり, 高さ別では, 床上 $0.5 \mathrm{~m}$ で $40.1 \%, 1 \mathrm{~m}$ で $37.4 \%, 1.5 \mathrm{~m} て ゙ 35.8 \%$ で,

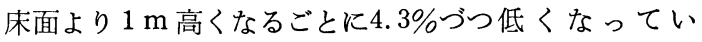

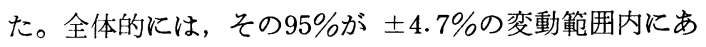
った。動物を收容後には $1 \mathrm{~m}$ 毎に約 $1.9 \%$ づつ上部の方 が低くなっていた。経日的測定では, 湿度は60〜 75\%の 範囲にあり, やや高い傾向を示した。

風速は床上 $0.5 \mathrm{~m} て ゙ 11.3 \mathrm{~cm} / \mathrm{sec}, 1 \mathrm{~m} て ゙ 11.6 \mathrm{~cm} / \mathrm{sec}$, $1.5 \mathrm{~m}$ で $12.0 \mathrm{~cm} / \mathrm{sec}$ で天井の方が高い傾向を示し, 床 面より $1 \mathrm{~m}$ 高くなるごとに約 $0.7 \mathrm{~m}$ ずつ高くなってい た。また，高さ別の風速のばらつきは上部の方が大きい 傾向を示した。

\section{1. 実験動物飼育施設の環境調查一I - 国立公衆衛生院 S P F 動物実験施設}

○吉沢 晋, 山崎省二 (公衆衛生院), 滝沢隆安 (家衛試)

実験動物飼育施設は，人を対象とした一般建物とは全 く異った内容を有するものであり, 実験動物施設として の技術体系を開発せねばならない点に, 基本的な問題が ある。

環境規制は, 実験動物の質の均一性や，環境条件から の実験上の誤差を除くなどの目的で行らが, 環境調查 は, 室の環境性能の把握, 施設相互の比較, 動物の環境 履歷の把握などを目的として行い，夫々適した方法があ る。ここでは, 環境性能把握, 比較のための測定方法を 応用した結果について述べる。

国立公衆衛生院動物実験中央研究室内の一室におい て, $50 \mathrm{~cm}$ 間隔の格子で, 床上 $50 \mathrm{~cm}, 100 \mathrm{~cm}, 150 \mathrm{~cm}$ の 3 位置の, 合計 255 点の測定点で, 温湿度, 気流の測定 を行った。室内中央, およびケージラック上に夫々 3 点 の計 6 点の定点測定も行った。

255 点の移動測定には小形電動式了スマン通風 温湿度 計 3 台, 定点測定では, 電気抵抗型アスマン通風計式变 
換器を有する温湿度記録計 6 台を用いた。気流速度は, 熱電対風速計を使用し, 各点での最大風速を求めた。 室内温, 湿度, 気流の分布を, 累積度数分布により, 中央值ならびに $90 \%$ レジとして比較したが，動物を入 れない場合と入れた場合とでは，あまり明確な差はみと められなかった。また, 測定值の分布に関し, $\mathrm{t}$ 検定を した結果，大部分は正規分布をなすとみとめられたが， 実際の分布はかなり凹凸の激しいもので，単純に統計的 な值からのみ比較するのは難点があることがみとめられ た。

\section{2. 国立ガンセンターにおける実験動物飼育方式の改善 について}

○藤本政晴, 宮本盛吉, 長沢 弘, 榑谷和男（国立がんセンタ一）

〔目的】実験動物の飼育管理を合理化する場合, 動物 舎の建物自体をはじめとして, 種々問題がある。事実, 自動化による飼育方式の利点を多としながらも，その実 施にふみきれない施設も，少なくない。私共は一般用の 建物を動物舎として用い, 飼育管理を行なっているが, この建物の条件下で飼育管理の合理化を図り, 飼育条件 の恒常化, 所定人員による飼育頭数の増大化ならびに省 力化を追求した。

〔方法〕改善の実施に際しては, 建物の改造はしな い, 既存ケージを最大限に利用する，動物飼育数の低下 をさたさないなどの条件を前提として行なった。

新飼育方式のための機材は, 一部従来の機材を改良し て利用し，その他は新たに設計したものを用いた。対象 とした動物種のららラット，八ムスター，モルモット， ウサギについては自動給排水による飼育方式とし，1 ヌ, サルについては床敷 (木屑) による飼育方式とし た。な扣サルの給水方法には吸飲式，イヌには貯留式の 飲水装置を用いた。

〔成績および考察】 新旧飼育方式によるラット150ケ 一ジの作業量について，その所要時間を比較すると新方 式は旧方式の $1 / 5$ であり，その消費労力は $1 / 20$ である。 これらはウサギ，モルモットについてもあてはまり，作 業能率は新方式の方がすぐれていた。イヌ, サルの床敷 飼育に拈いては，当飼育室の条件にかなって有利であ り，また動物の状態も良好であった。給水方法について は当所では発癌物質 (NG) の飲水投与も兼ねたが，こ の場合の NG の感光防止, 給水状態の安定化（涸渇, が ぶ飲み防止), また給水作業の簡便化にとって, 新方式 は有利であった。

以上のごとく, 飼育方式改善の結果, 給水の定量化, 省力化など, 当所に拈ける動物舎の整備事情に即応した 成果を持さめたものと考える。
73. 実験動物施設の環境統御 一シャワー廃止とその影 響について一

○久保文雄, 扣藤法子, 高橋徳太郎, 務台方彦，代田 稔（ヤクルト研）

[目的〕 Barrier System (B. S.) で必要とされて いるシャワーは実験者, 飼育管理者の健康管理, 実験・ 管理操作の複杵性等問題を残している。そこでわれわれ は, B. S. からシャワ一を廃止し, 微生物統御にどのよ らな影響を与えるかを検討した。

〔方法】作業衣は，ヒトと動物の接触を出来るだけ避 けるため, 目以外の部分を全て被覆するよらなものを用 いた。この影響を調べる方法として, Ex-germfree マ ウス, ラットの粪便菌叢の変化を月 1 回以上検索した。 使用培地は, MacConkey, Staphylococcus No. 110, SF, Potato dextrose, LBS, 変法 NBGT. GAM であ る。

〔結果】奏験に用いた動物の䔬便菌 叢は, Enteric bacteria, Bacilli, Streptococci, Fungi, Lactobaci1li, Bacteroides 等が free であり,この状態はシャワ 一廃止前 8 力月とシャワー廃止後 6 力月の観察期間中, 変化がみられなかった。しかし，7 力月以降の動物には 新しく Streptococci, Bifdbacteria の 2 種が出現し た。しかし, 大腸菌, 病原菌は認められなかった。

〔考察〕作業衣の改良により，シャワ一を廃止して も, Ex-germfree 動物の翼便菌叢に長期間変化がなか った。しかし，7 カ月以降に新たに上記の菌種が定着し たことは，B. S. の使用頻度，実験方法（複雑性）によ るものと考える。しかし, 大腸菌, その他の病原菌の污 染が認められなかった事は注目されてよいであろら。從 って，作業衣の改良等により，SPF 動物を飼育する方 法としてシャワーの廃止は, われわれの施設では可能に なった。われわれは，この方法による影響については， さらに検査項目を增加させ, 長期に観察を重ねていく必 要があると考えている。

[発言]

吉田 燦（千代田化工） 1 . 退出時に消毒楽を散布 しモップでふきとったとありましたが，飼育中におこな われたわけですか？。どの範囲について拉こなわれまし たか?。2. 飼育室の消毒楽散布は床面のみであっても 多少のミストペーパーの飛散はあると考学られますが, 病理検査をされてその影響と考えられる有意の変化はあ りませんでしたか? 。

久保文男（ヤクルト研） 1 . 動物飼育中の飼育室で は床面のみ, 他の清净域では, 全面に散布している。垁 験管理作業終了時に毎回实施している。2. この方法は B.S. の管理方法として一般にとられているものではな 
いかと思う。薬液散布によると考えられる異常はとくに 現在認めていない。

本庄重男 (予研) スライドで沶示しの作業衣類の材 質は何ですか。オートクレーヴにかけた場合に縮むこと はありませんか。市販されていますか。

久保文男 (ヤクルト研) 厚手の木綿地を使用, 洗濯 による縮みは, 使用したてに若干ある。オートクレーブ でとくに縮むと言う事はない。特注品である。

高橋 弘（実中研）特殊作業衣を着用した管理技術 者の方が，作業しやすいかどうか，汗をかくことはない か, の 2 点についてはいかがでしょうか?。

久保文男（ヤクルト研）慣れれば問題はない。むし ろ全身を打扣ら事による安心感のようなものも出て来て いる。発汗はほとんどない。

佐善喜二（日本クレア） シャワーの是非論はわれわ れも当面している大さな問題ですが今後益々発展させて 下さい。な和下着をつけていますか？。

久保文男（ヤクルト研）外部で各自着用のものその ままである。

坂口孝（ヘキスト・ジャパン）このような作業衣 で作業を行った場合外部へ放散する熱が遮られるため, 汗をかいたりなどして，作業者が気持が悪いと云らょう な事はありませんか。

久保文男 (ヤクルト研) 当初, 首周囲をきつく締め ていたため, 気分不快を訴える者が出たので, この点作 業衣を改良した。作業者の体型にあわせたものが必要で ある。

\section{生産 と管 理}

\section{4. オートクレーブ滅菌が飼料の消化・吸収に及ぼす影 豲について}

○山中聖敬, 斉藤宗男（実中研）

〔目的〕実験動物, 殊に germfree, gntobiotes, SP F 動物などの飼料は何らかの方法で滅菌しなければなら ない。そこで, オートクレーブ滅菌の場合, その滅菌操 作を加えることが飼料の消化・吸収にどのような影響を 及ぼすかをみるために，この実験を抗こなった。

〔方法〕 ICRマウス（合，早）を 5 匹の群飼として， 代謝ケージ内で 4 週間飼育し, その間, $1 \sim 2$ 日括きに 䔬・尿を全量採取し, フリーザー内に保存した後 1 週ご とにまとめて分析することとし，いずれのマウスにも非 滅菌あるいは滅菌 $\left(127^{\circ} \mathrm{C}\right.$ で30分間オートクレーブ) C L- 2 飼料を給与し, 同一個体で非滅菌または滅菌飼料 掑取時の成績を比較した。

〔成績〕滅菌飼料摂取時の純蛋白質の見かけの消化率
は, 非滅菌飼料摂取時よりも10〜20\%低い值を示した。 な拉, 粗蛋白質の見かけの消化率はこれと同じ傾向であ ったが，粗脂肪の見かけの消化率では両飼料の間に殆ん ど変化がなかった。次に, 滅菌飼料摂取時の窒素蓄積率 は, 先の蛋白質の消化率と同じく非滅菌飼料摂取時より も10〜20\%低い值であった。

[考察]オートクレーブ滅菌操作を加えることは, 飼 料の消化・吸収あるいは窒素蓄積によい結果をるたらさ ず，かえって栄養価（ここでは蛋白質の）を低下させて いる。例えば, 飼料中のアミノ酸についても, 化学分析 の場合は蛋白質を強酸で高温, 長時間に亘って分解した 後, アミノ酸を定量する。しかしながら, 動物の消化管 内では, 飼料蛋白質の様相が变わっている隇菌飼料の場 合，それをアミノ酸にまで分解することが困難なのかも 知れない。これらのメカニズムの解明は, 今後に残され た課題の一つであろう。

[発言]

中尾博之 (塩野義・油日) 我々の所でもバリヤーシ ステム運営に当りまして飼料の滅菌については問題にな ります。滅菌時間を30分のデーターを牧聞きしました が，滅菌時間を変えた場合 $\left(121^{\circ} \mathrm{C} 5\right.$ 分，10分）の成分 の変動について何かデーターを持ちでしょらか。

山中聖敬 (害中研) 今回は滅菌条件 (温度・時間)

と, 動物に括ける飼料の消化・吸収試験成績との関係に ついては実験していない。

橋本秀介（ヤクルト研）私共のラットを用いた試験 結果でも同様の結果を得ております。SD系成熟雄ラッ 卜に滅菌 NMF 飼料を与えた場合の粗蛋白質の見かけ の消化率は, 非滅菌, 放射線隇菌では違いは見られなか ったが，蒸気加圧滅菌では加圧時間が長くなるに従って 消化率が低下しました。

\section{5. 東大医科研・実験動物センター 4 階に設置されたオ 一トクレーブによる器材の滅菌に関する検討}

○前島一淑, 鈴木 潔, 小林理造, 須藤力ツ子, 伊藤喜久治（東大・ 医科研)

医科研動物センターに設置されたオートクレーブ（日 東理科) による, 無菌動物のための各種器材の滅菌条件 を検討した。

各種の条件でオートクレーブ処置した固型飼料（オリ エンタル $\mathrm{NMF} \cdot \mathrm{CMF}$, 船橋 $\mathrm{FI} \cdot \mathrm{F}$ II ) について, heart infusion ブイヨン $\left(37 \mathrm{C}^{\circ}\right)$, 臨床用 TGC 培地 $\left(37^{\circ} \mathrm{C} \cdot\right.$ 室温), cooked meat 培地 $\left(37^{\circ} \mathrm{C} \cdot\right.$ 室温), potato dextrose ブイヨン（室温）を用いた培養試験を おこなうと同時に，それを与えた無菌マウスの無菌試験 を試みた。その結果, $115^{\circ} \mathrm{C}$ ならば 30 分, $120^{\circ} \mathrm{C}$ なら 
ば20分， $125^{\circ} \mathrm{C}$ ならば15分で飼料は滅菌できることがわ かった。

つぎに, これらの滅菌飼料のビタミン $\mathrm{B}_{1}$ とビタミン $\mathrm{B}_{2}$ を定量した。ビタミン $\mathrm{B}_{1}$ はかなり破壊される（残存 率；20～50\%）が，オートクレーブ処置条件や製品によ る残存率の差異はあきらかではない。ビタミン $\mathrm{B}_{2}$ の破 壊はわずかであった。さらに, これらの飼料をふつらの マウス（DDD・市）飞与えて摂䬣量と体重を検索した が, 無処置飼料群との差はみられなかった。これらの成 績と実際上の作業能率から, 飼料のためのオートクレー ブの滅菌条件は, $120^{\circ} \mathrm{C} 20$ 分とセットすることにした。

大量の飲水を滅菌するためには, 飼料の場合にくらべ て，はるかに長い時間あるいは高い温度のオートクレー ブ処置が必要である。内筒へ急速に蒸気が導入できる高 性能オートクレーブでは, 内筒温度の上昇に水温はつい ていけない。たと党ば, 今回検索の対象となったオート クレーブでは, 滅菌条件を $120^{\circ} \mathrm{C} 30$ 分にセットしたと き, 飲水の温度は滅菌行程の終了時にやっと $70^{\circ} \mathrm{C}$ 前後 である。そこで, 多種の方法と条件について検討を加 光, 飲水の滅菌には, オートクレーブの条件を $120^{\circ} \mathrm{C} 90$ 分にセットすることが適当であると結論された。

床敷, ケージ, エアフィルターその他のオートクレー ブ滅菌については, とくに問題となる点はなく, 飼料と 同様, $120^{\circ} \mathrm{C} 20$ 分の処置で十分といえる。

\section{[発言]}

山崎省二(公衆衛生院) 公衆衛生院 SPF 施設では 無菌動物, Gnotobiote 動物を飼育するための材料（主 に飼料, 水, 床敷) は滅菌缶を用いてオートクレーブで 滅菌したものを使用する。この滅菌缶内の温度を, 熱電 対を用いて材料別に測定したので結果を知知らせ致しま す。床敷はオートクレーブ設定条件, $121^{\circ} \mathrm{C} 40$ 分で, $121^{\circ} \mathrm{C} 15$ 分の滅菌条件を満足させ, 飼料は $128^{\circ} \mathrm{C} 45$ 分の 設定条件で水は $128^{\circ} \mathrm{C} 2$ 時間で滅菌条件を満足させた。

\section{Pathogen Free Rabbits の育成}

○多賀谷修, 松原孝雄, 餅田久利, 橋本茂樹, 田中輝彦（エーザィ・生物研），木村 克， 鈴木四郎, 脇田隆治, 野崎良美

$$
\text { (カワシマ商事) }
$$

I 、はじめに

1）実験結果の精度, 信頼性の向上, 2）実験使用効 率の向上，3）飼育管理の省力化，を目標に，まず微 生物学的に良質な実験動物としてのウサギの育成を目指 し, Barrier 内に隔離した新生仔の人工哺育を行な い, Pathogen Free Rabbits の作出を試みた。

II. 実験材料招よび方法

供試動物は日本白色種の新生仔を生後 $7,10,14,16$
日後親から隔離し, ビニールアイソレーター内に収容し た。また使用器具類はすべて滅菌した後, アイソレータ 一内に搬入し, ミルク, 水, 固型飼料も滅菌後用いた。

ミルクの給与は 6 時間毎とし, また $20 \%$ ミルク, 固型 飼料, 水の給与は種々のスケジュールで行なった。これ らの搷取量は体重とともに毎日測定した。

Coccidium 検査は分画遠心法により行ない，また細 菌検査は親から隔離後10日間隔扣よび離乳時に行なっ た。

\section{III. 実験成績}

体重推移：各群ともに隔離日から $1 〜 7$ 日間横ばい状 態あるいは減少傾向を示したが，その後は自然哺育群の 増加勾配とほぼ同様であった。

ミルク・固型飼料・水の撕取状態: ミルクの人工給与 は数日間規定量以下の群もあったが，その後は規定量を 上回った。また，ケージに設置した $20 \%$ ミルクは，28日 令から, 固型飼料は29日令から本格的に摄取し, 摂水量 も固型飼料の摂取量が多くなるにつれて增した。

Coccidium 検査：生後26～32日令の間毎日検査し， 以後は一週間に一度, 定期的に行ない, 全例 113日令ま で陰性であった。

細菌検查 : 隔離後10日間隔および離乳時に細菌検查を 行なった。検出された細菌は非病原性のもののみであっ た。

IV。まとめ

我々は今回ウサギの実験動物化を目指し，7 日令以降 の新生仔の人工哺育で Coccidium Free Rabbits の 作出が達成できた。しかも早期に Isolation したこと により, 細菌学的にも Pathogen Free にできた。し かしながら自然哺育期間が長くなるとその污染の可能性 は十分考兄られるので, 今後はより早期に親から隔離す る必要があろら。

[発言]

宿田吉男（武田・光） このウサギの繁殖成績はあり ますか。

田中輝彦（エーザイ・生物研）繁殖性については, まだ，実験途中ではあるが，現在までに 2 母体使用して 共に分婏を認めている。妊娠期間は31日と予定したがい ずれる，それより 1 日間遅れた。Litter size は 9,4 であり, 前者の離乳仔は 7 , 後者は 4 匹で, 前者の死因 は圧死であった。

渋木 実(武田・光) コクシジウムフリーを得るた めにはウサギ出産日令の限界は何日でしょうか。私の経 験では生後10日及び15日令ではコクシジウムフリーで, 20 日令では $10^{4} \sqsupset / \mathrm{g}$ 程度污染 (腸内容物)されていま す。

田中輝彦・（エーザイ・生物研）本実験と平行して 
Coccidium の自然定着を追跡した。この場合, 母ウサ ギは市販のもので, Coccidium に濃染していたことを 確認してある。これを, 自動飼育装置で分婏させ, 定着 の追跡実験に用いたが，早いものでは，21日令の仔ウサ ギから Oocyst の検出を認めた。しかしながら，このよ うな飼育方法では, 木箱と異り, 污染は比較的軽度であ る傾向がみられる。

\section{7. 残留農薬研究所動物実験棟における空中細菌につい ての検查成績}

○高橋和明, 古橋彰子, 大沼富雄, 坂本年夫, 白須泰彦 (残留農薬研)

〔目的〕演者らは動物の長期飼育実験を目的に作られ た当研究所の Barrier System Block (以後 B.S. ブ ロックと記す）の清浄度を管理する目的で, B. S. ブロ ック内の空中細菌について, 同ブロックの消毒前, 消毒 後 (動物入室前)，動物入室後等にそれぞれ検査を行な った。

〔方法】送風空気の細菌検査はミリポア製空中細菌キ ッドを使用し，吹込口の空気を一定容量ろ紙を通して吸 引しそのろ紙にハートインフュージョン培地を浸みこま せた後培養した。落下細菌検查にはハートインフュージ ョン寒天培地 (シャーレ内径 $8.9 \mathrm{~cm}$ ) を，カビ検查には サブロー寒天培地を使用し, 原則として60分間露出し

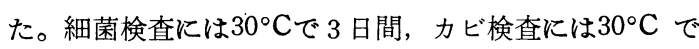
5 日間好気的に培養し, 発育したコロニ一数を值とし た。

\section{〔成績ならびに考察〕}

1. 送風空気の細菌検査を行なった結果, B. S. 系統 ではほとんど菌は検出されなかったが, conv. 系統では ある程度菌が検出された。

2. B. S. ブロックとその周囲の落下細菌・カビの検 査を経時的に行なった結果, B. S. ブロックに护落 下細菌は同ブロックの消毒後減小したが，その後動物の 入室およびその収容匹数の増加にともない増加する傾向 を認めた。動物入室後の昼 (AM11：30’〜PM12：30') と夜 (PM11：30’〜AM0：30') の成績を比較すると明 らかに夜の方が細菌数が増加した。B. S. ブロック落下 細菌のグラム染色による分類では, 消毒前はグラム陽性 桿菌の割合が多く, 消毒後 (動物入室) の検査ではグラ 么陽性球菌の割合が多かった。B. S. ブロックとその周 囲に括ける落下細菌・カビ数を比較した結果, B. S. ブ ロックの方が明らかに菌数が少なく清浄であることがわ かった。

[発言]

前島一淑（東大・医科研） 空中細菌は, どこに由来 するか。とくに, 菌そらが, 桿菌から球菌に変ったこと
を,どら解釈したらよいか。

高橋和明（残留農薬研）菌の同定を行なっていない のではっきりとした事はわかりませんが，現在の段階で は球菌は動物由来ではないかと考えています。

山崎省二 (公衆衛生院) 1 . 空中細菌測定用器具と して millipore filter 法を用いているが，私達のデー ターでは同法で大量の空気を吸引すると空中細菌が死ん でしまう心配が出たが，その点はどうでしたでしょう か。2. 空中細菌の測定に落下法を用いているが，空中 細菌と落下法との関係はどうなっていますでしょらか。

高橋和明 (残留農薬研究所) 1 . 空中細菌測定用器 具として millipore filter 法は現状では㕕く用いられ ており, 我々も同法にしたがった。本法に代りらる広く 公認された方法を知っておられましたら御教授下さい。 2. 高垣らは落下法について, 同法にて同一条件下で検 查した成績を比較することは十分意味があり，それによ って空中細菌数を把握することは可能であると述べてお り, 我々も同一時刻に多くの室の空中細菌を簡単に調べ られる方法として本法を用いた。

\section{8. 日生研におけるウサギ（JW-NIBS）の生産につい $\tau$}

梅沢英彦, 由井福男, ○矢沢 肇, 倉益茂実 (日生研・実動研)

日生研ウサギ（JW-NIBS）の起源は, 長い間（20 年以上）他からの導入の記録なしに飼育されていた日本 白色種コロニーの, 同腹の雌 4 , 雄 1 から1964年に出発 したクローズド・コロニーである。このコロニーの1967 年より 5 力年にわたる, 飼育概要及び繁殖成績と, 発情 に対する若干の知見を報告する。

飼育舎は木造モルタル及び, 鉄骨ハウス（改造）で, 飼育ケージは木製で, 大きさ形式ともそれぞれ繁殖, 育 成, 飼育用に区分されている。また飼料は自家製固型飼 料を使用し, 水は自動給水している。特に発育期に括け る飲水量は300〜 $500 \mathrm{cc}$ と多い。繁殖については, 初発情 は 4 4.5力月令, 繁殖適令期は雌6. 8 力月令, 雄 6 力月 令である。交配方法については, 各世代にわたる遺伝子 頻度の安定性を計る為めに, ローテイションシステムで 行なっている。繁殖成績の変遷を見ると, 年平均受胎 率 $89.2 \%$, 離乳率 $86.6 \%$, 産仔数 6.8 匹となり, 夏場に 扣いて季節的影響がややうかがわれたが，年間安定した 計画生産が行われている。

発情については, 動物の行動及び陰部所見, その他我 々の経験からではあるが，耳温度差による見分けがつく のではないかといら結果が得られた。周期については, 明確な結果が得られなかったが，交配時に扣いて全体の ウサギの発情が増すといら点が観察された。今後はこれ 
らの問題とともに内面より卵胞の発育速度, 及び発情, 妊娠，哺乳期に打けるホルモン関係について併せて，両 面から検討して行きたいと考えている。

\section{[発言]}

鈴木 潔（東大・医科研） 1 . 交配は発情度と関連 づけて行ないましたか。2. 交配期間は 3 日間に限定し たそらですが，市合 3 日同居で偽妊娠がみられません か。

矢沢 敏 (日生研・実動研) 1 . 発情度と関連をつ けて交配しています。2. 交配期間 3 日というのは, 毎 月定期に行っている20２5匹のウサギ全部が，交配を終 了するまでの期間をいいます。 3 日間同居させているわ けではありません。交配は, 交尾回数 2 回を確認後, 雄 から雌を離します。偽妊娠については殆ど見当りませ 几。

浅倉晴弥（武田薬品・生研） 交配方法について, 人 工的にほう助して交配を行っているか?。

矢沢 箨 (日生研・実動研) 交配時に人口的補助は 行っていません。

79. 精製飼料によるマウスの飼育・繁殖について（I ）

○岩田寿雄, 三鴨信秋, 北村佐三郎 (オリエンタル酵母)

〔目的】実験動物の質的向上と動物実験精度の向上と がなされるにつれて, 実験に用いられる飼料も, 款類, 魚粉等の天然原料を使ったものから, 内容, 組成を明確 に把握するために各栄養素が比較的単一原料から由来す る様に, カゼイン, スターチ, 油脂等を使用した精製飼 料を用いる実験例が外国及び国内でも多くなり, 報告さ れているが，これら実験に用いる基礎飼料としての標準 的な飼育例, 繁殖例は少なく, 特に精製飼料による継代 繁殖例は見受けられない。そこで, 満足し得る飼育・繁 殖が可能な精製飼料の標準的組成を求める目的で配合検 討を行なった。

[方法]カゼイン， $25 \%$ ，スターチ， $48 \%$ ，砂糖， 5 $\%$ ，サラダ油， $6 \% ，$ セルロースパウダー， $8 \%$, ビタ ミン類， $2 \%$ ，ミネラル類 $6 \%$ からなる精製飼料を粉末 又は固型にて，クローズドコロニーにて維持されている マウス（C57BL/6）に給与し，継代繁殖を行なった。 交配方法はㅇ $2 \times \hat{8} 1,10$ 日間同居とした。継代は各世 代第 2 産仔を次代に残した。

〔成績】 10 週令迄の発育では, $4 \sim 6$ 週令迄は精製飼 料が従来特殊繁殖用飼料 (CMF) での発育よりやや上 廻り，6〜8 週令で逆転する。体重 $20 \mathrm{~g}$ に達した 9 の飼 料椇取量は精製飼料 $2.7 \mathrm{~g}, \mathrm{CMF}$ 飼料 $3.1 \mathrm{~g}$ であった。 6 世代迄の継代繁殖成績は，平均生産率，84\%，産仔 数, 7.4 匹, 離乳率, $72 \%$ であり, $\mathrm{CMF}$ 飼料では, 出
産率， $72 \%$ ，産仔数， 8.1 匹，離乳率，92\%であった。 〔考察】前述の配合組成による精製飼料での発育・繁 殖成績を得たが, CMF 飼料での成績と比較し十分実験 用基礎飼料としての標準的配合となし得る事がわかっ た。しかしながら，今後更に検討しなければならない事 は, 離乳率の向上であり,ビタミン, ミネラル量につい ても，更に過不足の解明を行なら。

\section{[発言]}

藤井 孝 (東京都衛研) 採食量の相異, 差の因子の 中に占める動物の嗜好といら点についての考穴は。

岩田寿雄（オリエンタル醉母）採食量に影響を与え る因子としては，動物自体の体調その他を考学ずに，飼 料の面からの及考学ると，に打い，味などの嗜好性，飼 料の硬さ, 給䬣器の形状及び設置場所などが主因子とし て考兄られる。本実験での採食量の差は, この因子のう ち，飼料の硬さが大きく影響した。

鈴木 潔 (東大・医科研) 合成飼料とか半合成飼料 といら用語を用いないで，精製飼料と云った意味は?。 岩田寿雄（オリエンタル醉母）実験動物用飼料を, 使用する原料の違いによって天然飼料, 精製飼料, 合成 飼料の三つに大別したいと考兄ている。すなわち，天然 飼料とは天然原料（穀類，魚粉，糟棣類）から作られた もの, 精製飼料とはカゼイン, スターチ，セルロースパ ウダー, 精製油脂類等から作られるもの, 合成飼料とは 蛋白源としてアミノ酸混合物, 炭水化物源として単糖 類, 脂質源として脂肪酸混合物などを使って作られる飼 料のこととしたい。

\section{0. 系統マウスの繁殖成績と計画生産についての一試案}

○宮本盛吉, 長沢 弘, 藤本政晴 （国立がんセンター）

[目的】実験動物の生産を効率よく行なら場合, その 動物のもつ繁殖性について, みずからが把握した基礎デ 一夕を用いる必要があると考学る。私共は当研究所で系 統繁殖している8 系統マウスの繁殖成績を調べ, これら の繁殖性にもとづいた生産方法, とくに追っかけ妊娠に よる計画生産についての試案を作成した。

〔方法】用いた動物は 8 系統のマウス ( $\mathrm{C} 3 \mathrm{HeB} / \mathrm{FeJ}$ ax, C3H/HeMs, C57BL/6Jax, CBA, BALB/cHe, A, $\mathrm{R}$ II, $\mathrm{DBA} / 2)$ で, 動物数は各系統25 32匹である。交 配は約70日令で雌雄各 1 を同居させ，3産まで追っかけ 妊娠させた。繁殖成績としては各系統, 各産次ごとに交 配分婏間隔, 分婏時母体重, 分婏率, 産子数, 0,12 , 20 日令平均子体重，12日令増体率，12，20日令育成率等 を各個体ごとに，3 産まで毎世代調べた。飼養条件とし ては, 飼育室を温度, $24 \pm 0.5^{\circ} \mathrm{C}$, 相対湿度 $65 \sim 70 \%$, 午前 8 時〜午後 8 時の 12 時間人工照明を行なった。飼料 
は日本クレア製繁殖用（CA-1）を自由採食させ，床 敷は週 2 回交換した。

〔結果および考察】8 系統のマウスを通じ系統内産次 間，系統間に打いて分婏間隔に大きな違いはみられず， 約 4 週間であったが, BALB/cHe のみ約 5 週間であっ た。他の成績については別紙 (表) のごとく系統間に相 違がみられた。これらの成績を計画生産の実際にあては めてみると, 週単位の生産を基準とした生産 群の編 成 は，交配分娩間隔の成績から BALB/cHe については 5 群, 他の系統は 4 群を必要とし, 生産数の具体例を示 すと, 週 100 匹の生産目標に対して例えば, 繁殖効率の 比較的よい $\mathrm{C} 3 \mathrm{HeB} / \mathrm{FeJax}$ に拈いては生産親のケージ 数は76個を要し, 効率の悪い $\mathrm{DBA} / 2$ に括いては200ケ 一ジを必要とする。このことから系統マウスの計画生産 にあたっては, それぞれの系統自身の繁殖成績にもとづ くことが重要であり, 追っかけ妊娠方式による生産数の 計画化が可能であると考える。

\section{[発言]}

鈴木 潔（東大・医科研）追いかけ妊娠方式による 計画生産の資料とするために，Lane-Petter のQ計算 を試みたら，いかがですか？。

宮本 盛吉（国立がんセンター） われわれの方式を 実地に検討してみるとともに，仰せの方式る是非検討い たしたいと存じます。

\section{1. 久留米大学医学部動物実験センターの管理運営につ} いて

○野田安孝, 山口誠哉（久留米大・医）

医学に関する動物実験, 実験用動物の管理, 研究等を 行ならために, 従来分散していた各科の動物室, 動物実 験室を一力所にまとめて管理するとともに, 実験の安全 と精度の確保に必要な安定した環境条件を提供すること を目的として，動物実験センタ一が完成し，昭和45年 4 月より運営を開始した。施設の概要については千代田化 工建設 $\mathrm{KK}$ Kよりすでに報告ずみである。現在学内に沶い て要求される動物の質と量は, 飼育室の環境レベルと収 容能力にほぼ合致して扣り, 飼育管理すべてをセンター で行ならょうになって,ひじょらに順調に飼育され感謝 されている。動物, 飼料はセンターで一括購入し, 動物購 入費および飼育管理費は各講座の研究費あるいは個人か ら徴収している。すなわち使用者負担であるが，センタ 一の維持運営費 (人件費, 光熱水費等) は大学から出す といらことをたてまえとしている。動物実験センター規 程が制定されて扣り, 実験動物は全てセンターに収容す ることになっている。管理部門, 犬実験部門, 感染実験 部門, 発癌実験部門および一般動物飼育実験部門からな り, 各部門の運営委員長と医学部長, 病院長をもって動
物センター委員会を組織し，管理運営に関する基本方針 を審議している。各部門運営委員会はセンタ一委員会が 定めた基本方針に基づき，センターの日常業務の運営， 使用上の連絡調整その他必要な事項を審議している。施 設を運営していく上で一番苦労したのは, 飼育技術者, 各研究者はもちろん各部門の運営委員とか, 事務関係, 施設関係の人などの力をセンターの管理運営にいかに結 集するかということであった。まだ充分とはいえない が, 本センターが実験動物の改良, 研究および動物実験に 関するサービスに，大学に拈ける中央施設としての役割 を果たすことがでさるように，単に動物の集中飼育機関 と考えるのではなく，独立した動物実験施設として機能 するように更に充実，整備したいと考えている。

[発言]

近藤恭司 (名大・農) 同種類の実験動物で, テー マ, 操作の違う動物実験が行なわれる場合, どのように マネージされますか。

野田安孝 (久留米大・医) 感染動物飼育, 実験室は 9 室, 30個のドラフトチェンバーがあり, 発癌実験はウ サギとマウス，ラット用 2 飼育室および処置室がありま すが，その他一般動物実験は, 異種の実験内容のものを 同一室に飼育せざるをえない状態であります。

\section{2. 動物実験センターにおける施設点検の実際とその結 果}

野田安孝, ○田中智久, 稲吉三男

(久留米大・医)

久留米大学医学部に括いて昭和 45 年 2 月動物実験セン タ一が完成した。不安定な人員構成のなかで, われわれ が行なってきた施設の管理点検の結果をまとめた。空調 設備, 機械の故障, 施設維持のための電力, 重油, ガ ス, 食塩使用量, その他飼育室内のミク口気象などにつ いても併せ報告する。飼育施設は 4 階および感染飼育室 は Barrier System で, 他に一般動物飼育室, 手術 室, 実験室等が配置されている。Barrier System で は高性能フィルターで除菌された全外気空気調和を行な い, 他はファンコイルュニットにより空気調和されてい る。飼育室内温度は, $23 \pm 1^{\circ} \mathrm{C}$, 湿度は $55 \pm 5 \%$ であっ た。室内のアンモニア濃度は, 最高 $20 \mathrm{ppm}$ あったが, これは床敷交換回数, 換気回数を増すことで減少させて いる。騒音については, 機械室が 2 階に設置されている ため, 飼育室内で最高55ホーンあり, 排気ダクトの吸音 処理, 機械の改良等対策を行なった結果, ある程度の効 果があった。落下細菌検查は毎月 1 回行なっているが, 現在まで病原性の細菌は検出されていない。空調機の故 障は, ボイラー罐体のパンク，冷凍機のコンデンサーチ ューブのパンクを経験した。原因を検討した結果，水質 
不良によるものと考えられ，ボイラ一に対しては連続ブ ロー装置の取付, 清罐剤の連続注入など, 冷凍機に対し ては, アンモニアイオン, 塩素イオン等の除去を行らた め, クーリングタワー付近にある排気筒の移動, 煙突の 延長, 冷却水のオーバーフローなどの対策処理を行っ た。その他, 給気, 排気フィルターの目づまり, 冬期の 飼育室内の結露等の問題があった。

\section{[発言]}

高橋 弘 (実中研) 温度・風速の室内分布測定の 際，上，中，下の区別はどのようにして決められました か? 。

田中智久（久留米大 - 医）測定時の上，中，下の区 別はラックの最上段を上, 中段を中，最下段を下と別け ました。な挔，室内の測定点は33点行ないましたがスラ イドには12点だけしか示して拉りません。

高橋和明（残留農薬研）排気のミクロンフィルタ一 のチェックはどの様にやって拈られますか。

田中智久 (久留米大・医) 飼育室内のドラフトチェ ンバーについているボックスフィルターはU字型マノメ ーター, 各飼育室より集合したフィルターは丸型マノメ 一ターを用いて括り，マノメーターに正常時の目盛を付 けておいて目づまり時との水位又は針のふれの差により チェックして拉りす。

\section{3. 和歌山医大 ・実験動物センターのその後の運営につ いて}

○西村正彦, 辻 繁勝, 松下 宏 （和歌山医大）

第 6 回研究発表会に括いて昭和 45 年 4 月開設後 1 年間 の当施設の設備能力および飼育環境等の概要について報 告した。今回は昭和 46 年度 1 年間の動物の利用状況およ び生産状況について報告する。

独自に動物飼育室を有する分校打よび基礎の数教室を

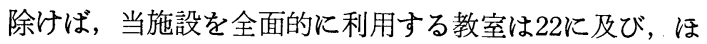
ぼ全学的な共同利用施設としての役割を果している。飼 育管理にたづさわる人員は 5 名であり, 内訳は 1 日 8 時 間が 2 名, 3 時間が 3 名である。

年間 1 日平均飼育匹数は犬約 50 , 猫 10 , 鬼 150 , モル モット50, 八ムスター150, ラット500, マウス 3,000で あり, 動物入舎・退舎の回転により収容スペースを有効 そ使っている。

学外よりの動物購入は猫を除き必要頭数をスムーズに 入手出来るが，市販されていない系統の維持特よび供給 のために，ラットに护ける 2 近交系及び 2 ミュータント 系, 八ムスタ一の 1 近交系, マウスの 12 近交系と $12 ミ$ 一タント系を自家繁殖して扣り，実験に使用される八厶 スター及びマウスの $90 \%$ 以上を自家生産により供給して
いる。各系統の交配ぺア数と月産匹数によって生産状況 を説明した。

特に劣性ホモ不妊のミュータント系についてへテロペ アを入手後, 目標生産数汇達するまでの経過を記すと, C57BL/6J-dy の場合, ヘテロ10ペアより增殖開始し, 月産ホモ60匹に達するのに 9 力月を要し，このときの交 配中へテロペア数55を維持するのに月産同定へテロ 5 〜 15ペアを必要とした。C57BL/6J-ob の場合, 5 ペアの ヘテロを入手後, 月産ホモ30匹を得る迄10力月を要し, 交配中へテロペア数25を維持するのに月産同定へテロ 2 〜 7 ペアを必要とした。C $57 \mathrm{BL} / \mathrm{KsJ}-\mathrm{db}$ の場合, 月産 ホモ20匹を得るには10力月を要し, 交配中へテロペア数 15を維持するのに月産同定へテロ 1 〜 ペアを必要とし た。

\section{4. 電子計算機によるマウスの飼育管理について 第 2 報}

藤崎年英（和歌山医大）

第 5 回本研究会及び実験動物 Vol. 20, No 3 で報告し たが，マウス飼育管理データ処理システムの準備段階を 終え可動態勢が完成した。使用電子計算機は FACOM 230-20中型電子計算機で, データ処理はオフラインバッ チ処理で行なっている。

動物舎で集収されたデータは IBM 29 カード穿孔機 によりパンチカードに穿孔された後，カードチェックを 行なった後磁気テープに格納されその後, 死因調査, 出 産成績調査等の各処理が行なわれる。

各データ処理時間はカードチェックから現在用意され ているプログラム全ての処理まで約 1 時間程度である。 また，パンチされるカードは 1 日当り約 250 枚程度で必 要時間は $1 \sim 2$ 時間である。

今後飼育管理者あるいは研究者からの要求も増加する ことが考えられ，これらの要求に応じるべくプログラム を開発增加させていく予定である。

\section{5. マウス交配時の雄雌同居最適比率について}

○野崎良美（カワシマ商事）, 田中輝彦（エーザイ・生物研）

実験は, 繁殖効率の向上, ケージスペースの狭少化, 飼育管理の省力化の 3 点を目指し行なった。交配率を示 標とし, 雄雌同居時の最適比率を求めた。<自然発情の 場合の交配比率について>方法は，合 1 匹・ 2 匹・ 3 匹 - 4 匹. 5 匹に対し, + 1 匹・ 2 匹・ 3 匹. 5 匹・ 7 匹 の割合で各 3 群ずつ, 6 日間同居させ交配した + $/$ 発情し た $\times 100$ の数式で交配比率を出した。この結果として は, ○ 2 匹群が最も高く, 次いで 5 匹群, 4 匹群, 3 匹 群の順で 1 匹群は極端に低い率を示した。早群では 7 匹 
群が最も低率であった。組み合せ別では，影：守が 2 ： 1・2:2・3:2 が 100\%を示し, 次いで $4: 2 \cdot 4$ : $3 \cdot 5: 3 \cdot 5: 5$ が高率を示した。妊娠率は, 全般 的に大差が見られず，平均 $70 \%$ の高率を示した。今複数 群における闘争で損失した今の匹数は，2：1・3：1 - $3: 2 \cdot 3: 5 \cdot 4: 2$ では, 闘争は見られたが, 損 失は全くなかった。全般的に見ると, 今 4 匹以上ㅇ, 3 匹以上の飼育密度の高い組み合せで, 損失が多く見られ た。〈発情を同期化した場合の交配比率について〉方法 は, 3 日間卵胞ホルモン本筋肉内注射して同期 化させ た。その早におを, 自然発情の場合と, 同じ割合で同居 させた。結果は, 全般的に, 今 4 匹群の交配比率が高 く, 11 匹群が最も低い率であった。この実験でも, 単数より複数の方が高率を示した。以上の結果とし て, 交配時に今複数同居させた場合, 今の闘争はまぬが れ得ないが， ○ $2 \sim 3$ 匹: ㅇ $2 \sim 3$ 匹の比においては, 交配比率が高かっただけではなく，令の損失が少なかっ たといら結果が得られた。合 $2 \sim 3$ 匹：+ 2 ๔ 3 匹で交 配させることによって, この目的を達しらるものと, 思 われる。

\section{[発言]}

辻紘一郎（中外・綜合研） 交配率あるいは交配比率 という用語を交尾率について使われているが，特別の意 味を持たれるのか?。

田中輝彦（エーザイ・生物研）交配比率といら表現 をとったのは, 交配率といら用語との混同をさけるため で，特に意味は持っていない。助言を御受けしたように 今後は交尾率と表現したい。

石島芳郎（東京農大）交尾の確認はどのようになさ いましたか。交配比率は繁殖学用語として不適当ですか ら交尾率といった方がよいと思います。

田中輝彦（エーザィ・生物研） 本来ならば, 交尾の 確認は sperm 確認によるのが妥当と思われるが, 今回 は plagueによった。この場合の妊娠率は, plague 確 認のものに一致した。交配比率の用語が繁殖用語として 不適当で交尾率との表現がよいとのこと, 助言を御受け し, 訂正致します。

\section{6. マウスの反復過排卵誘起}

石島芳郎（東京農大）

性腺刺激ホルモンによる過排卵誘起が, 産子数の増進 や研究用卵子の生産に利用されているが, 近年, この過 排卵処理をくり返すと次回以降の反応がにぶくなること がいくつかの動物で指摘されている。このことは，過排 卵を応用していくらえで支障になる問題なので, マウス についてこの点を検討した。

CF\#1 未経産マウスにPMS 5 IU を皮下注射し，つい
で48時間後 HCG 5 IU を皮下注射する方法を用い，これ を10，20および30日間隔でそれぞれ4回までくり返し， それぞれの時点の排卵数を検査した。

その結果, 供試マウス 1 群の平均排卵数は, いずれの 区も 2 回目までは変化なかったが， 3 回目以降は有意に 減少し，4回目では初回の 1/5 1/10 程度の卵子しか得 られなくなった。排卵陽性率は，10日と20日区は 3 回目 以降，30日区は 4 回目に低下し，回がすすむにつれ，排 卵しない個体が増加した。排卵した個体のみの卵子数を みても，3回目以降は初回の $1 / 2 \sim 1 / 3$ 程度に減少してい た。また，排卵反応が有意に低下した 3 回目以降は，い ずれの区の卯巣重量も極端に減少していた。これらの反 応低下の傾向は, 処置間隔が短いほど顕著のようにみう けられたが，この処置間隔による差は統計学的には有意 とはみとめられなかった。つぎに，追試の意味で dd マ ウスに同様の処理を10日間隔でくり返したところ，やは り回がすすむにつれ, 排卵数, 排卯率の減少がたしかめ られた。

以上のことから，マウスに拈いても過排卵処理をくり 返すと排卵反応が低下することがあさらかとなった。こ の知見をふまえ今後は，この原因の解明と改善策を検討 していきたい。

\section{[発言]}

中村経紀（麻布獣大） マウスを用いての過排卵の実 験では，個体差がマウスの場合多いと考えられなかった か。

石島芳郎（東京農大）たしかに反応には個体差がみ られました。しかし，今回の場合，過排卯処理を反復す ると排卵数が減少する傾向は, 個体差をこえて有意な差 がみられたので，あきらかに処理回数による低下と考壳 られます。反応の個体差を考えると，こうした実験の場 合同一個体で反応の推移をみる必要があると思います が，実験しにくいのでやむなく一群の結果をみていま す。この原因について, 従来から卵巣の反応性がなくな ることと, アンチホルモンの産生が指摘されていて, 私 も複数の原因を考劣ています。本日発表しませんでした が，すでに反復処理を 3 回くり返したマウスからの血清 をPMS に加えて反応をみますと, 過排卵対照の卵子 数23.1 コに対し, 血清を加えたものは 9.0 コであきらか に抑制がみとめられる知見をもっています。一方, 今回 のデータで処理が進むと卵巣萎縮がみられていますので この点も無視できないと思います。今後は両面から原因 を追究する所存です。

\section{7. 昼間飲水率からみた不適照明時間の限界}

村上 宏（神戸大・医）

〔目的〕 マウスの群について昼間飲水率 (WRD) が 
有意差のある变動を示すような照明時間の限界を求め る。

〔方法】 80 匹の $\mathrm{ICR} / \mathrm{JCL} / \mathrm{T}, 4$ 週令早マウスを各 8 匹の10群に分け，金網ケージに個別に収容したのち， 1 日の照明時間を $22,20,19,18,17,8,7,6,4$ ，および 2 時間の 10 種類に設定して, 各群のWRD の変動を経日 観察する。

〔成績〕 WRD の変動は 1 日の照明および暗黒の時間 差が大きい群ほど著明であり，実験開始時に打けるWR D の初期值に対して有意差の変化が現われたのは，1日 19時間以上および 7 時間以下の照明群であった。

[考察] マウスの昼間飲水量が 1 日の飲水量中に占め る比率をWRD とするとき，マウスを連続照明または 連続暗黒に飼育すると，WRD は前者に扣いては約 20 日，後者ではそれより著しく長い周期で変動する。WR D が高い值を示す時期は本来夜行性のマウスが昼行性の 状態に転換しているものと考只られ，したがって各種の 生理值が測定される長期実験において，マウスを連続照 明または連続暗黒のみでなく，本実験で求められた限界 以上に明暗の時間差がある照明条件で飼育すると，日々 のデータが不安定になるであろうことは容易に推測され る。

また動物の群としてではなく，各個体についてWRD の変動が最小になるよらな照明条件を求めれば，データ を安定させるのに最適の照明時間が決定できよう。この ことは動物を年中同一の照明条件で飼育するのと, 自然 界の日照時間の季節変動を加味するのとどちらが望まし いかを決定するさいにも一つの規準とすることができ， さらにまたアルミ製などのケージはケージ内外の照度差 が著しく異なるから，データの安定を目的とする観点か らその影響についても検討する必要があると考えられ る。

\section{[発言]}

奥木 実（都老人研） 照明時間の影響については, 飲水量だけでなく，掑食量，運動量などにも関係すると 思われるので測定されておられたら教えて頂きたいと思 います。

村上 宏（神戸大・医）摄食量は摂水量にほ湆此例 し，計測するまでもないと考えたため測っておりませ ん。運動量の連続照明下に和ける变動は昼間飲水率の変 動によく平行しています。

登倉尋実（京大・霊長研） 1 . 昼間飲水率が照明時 間が 1 日に19時間以上の場合は有意に上昇するといらこ とですが，そういう照明条件下にマウスの endogenous な飲水リズムが entrain できないといらことから生じ ると考えていいでしょらか。2. 連続照明または連続暗 洄のもとでは，本来夜行性のマウスが昼行性に変るとい
うことが講演抄録に書いてありますが，こらいら表現方 法は正しくないと思う。あくまでマウスの夜行性といら 性質は変っていなくて, 本来マウスがもっている24時間 ではない生物時計がその自発周期にしたがって，いわゆ る free-running の状態を示している。したがってみか け上偶然地方時の昼間に飲水率が上昇することがあるわ けで，このことをもってマウスが昼行性に变るというの はよろしくない。飲水率が地方時の昼間時期に上昇する 時期があると表現すべきである。

村上宏 (神戸大・医) 1 . 連続照明下での昼間飲 水率に関するいままでの実験はもっぱら現象面だけのも ので, その発現機構については全く検討して叔りません ので，現時点では御質問に扮答えできません。2，昼間 によく水を飲み, また活動量る多いといら「状態」を指 して抄録には「昼行性の状態に变わる」と記したので, マウスといら「動物」そのものが昼行性になったといら 意図ではありませんが，御指摘のような誤解を生じない よう表現に注意いたします。

高橋和明（残留農薬研） 私は NCS 系マウスで14時 間明10時間暗の条件下で水消費量・餌消費量・䔬量等を 観察した事が御座居ますが，その際これらの值が点燈， 消燈前後に增加する事を認めています。先生の述べられ ている夜行性のマウスが日によって昼行性の状態に変る と云う点において, 私の認めた点燈, 消燈前後の増加の 山が日によって昼の方にややずれるとも解しゃく出来ま すがいかがでしょらか。

村上 宏（神戸大・医）連続照明下で昼間飲水率招 よび自発的活動量を 3 週間あまり観察した経験では, 御 指摘のように点燈・消燈時前に特徵的な变化が認められ るということはありませんでした。しかし，トリ(Leiothrix lutea Scopoli）を毎日18時消燈の明暗サイクル から連続照明へ移すと, その初日のみ18〜19時の 1 時間 に著しい活動量の増加を見ております。

\section{8. ハムスターの性周期に及ぼす光の影響一夏期におけ る照明条件の検討}

中野健司, ○沓掛源四郎，今泉 清 (予研)

〔目的〕 予研の八ムスタ一繁殖コロニーに拈ける妊娠 率が冬期著しく低下することは発情周期が光周期の变化 の影響をうけ，正しく4 日周期をくり返えさないためで はないかと考光，冬期に和汀る照明条件を検討した。そ の結果照明条件を一定にすることによって冬期性周期の 規則性が維持されること，扣よび照明条件の変化は性周 期の規則性に影響することが確かめられた（第 5 回研究 発表会で報告)。今回この照明条件の影響が自然光下で 繁殖に支障を来さない夏期（ 5 月一 9 月）飞扎いてもこ の照明条件が 4 日周期にどのように影響を及ぼすかにつ 
いて検討した。

〔方法〕方法は前回と同様月令別に一群 6 匹が各照明 条件に各々用いられた。条件転換は夏期は 5 月に行なわ れた。4 日周期の規則性は腔分泌物性を指標にして追跡 された。

〔成績】自然光における性周期は冬期では一時的に不 規則となり， 発情後期の stage が消失するが夏期では 正しく4 日周期をくり返えしている。人工照明（LD12 :12) で，冬期は多少の不規則性がみられるが夏期では 殆んど乱れがみられなかった。照明条件の変化について は, 連続照明への転換群で冬期と同様夏期でも 4 日周期 は乱れて再び正常周期に戻らなかった。人工光（LD12 :12) から自然光へ, 自然光から人工光 (LD12:12) への転換において前者にあっては冬期に一時不梘則性が みられたのに反して夏期で全く変化がみられなかった。 後者にあっては逆に冬期では変化がみられなかったのに 夏期では一時期 4 日周期の乱れがみとめられた。

[考察] 以上の成績から照明条件の変化は四季を通じ てハムスターの性周期に影響を与え, 正しく 4 日間周期 を維持するためには一定の光周期が必要であることが確

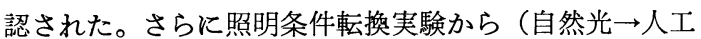
光）（人工光 $\rightarrow$ 自然光）日照時間の長短にも性周期の規 則性は支配されることを示唆する成績が得られた。

89. 実験動物と騒音 V. 騒音環境で飼育したラットの体 重および採食, 飲水量について

○井都泰, 高橋 弘（実中研）

〔目的】実験動物の飼育環境に発生する騒音が，そこ に飼育されている動物に，どのような影響を与えるかに ついて知ることを目的とした。

[方法]

供試動物は SD-JCL ラットふ里計50匹とした。これ らのラットは 3 週令時に, 騒音環境（今。各15匹）と普 通環境（今12, ㅇ 8 匹）に無作為にわりつけ, 23週令ま で飼育した。

騒音環境は，85ホンのホワイトノイズを 3 時間間隔で 3 時間ずつ発生させ, ラットは 1 日につき 12 時間, 騒音 環境下で飼育されるようにした。普通環境には暗騒音 60 ホンの飼育室を使用した。

この間の体重, 採食量, 飲水量を測定した。更に, 騒 音の影響が生理機能面に現われる一現像として, ラット の自発運動について観察した。

〔結果】実験開始時の体重は今 +共に騷音群と対照群 の間に差はなかったが， $5 \sim 6$ 週令（実験開始後 $3 \sim 4$ 週目）から差が見られ始め，23週令時の体重は令で騒音 群542g, 対照群603g, 우では䮎音群 $324 \mathrm{~g}$, 対照群 $367 \mathrm{~g}$ と なり, 今早共に対照群の方が騒音群より大きく, 両群間
に有意差が認められた。

採食量, 飲水量については両群間に著明な差は認めら れなかった。その結果, 騒音群の飼料要求率が対照群の それより高い値を示した。この結果は，先にマウスを用 いておこなった実験成績とも良く一致した。

又自発運動の測定の結果，音刺激によりラットの自発 運動は著明に増加した。

〔考察〕以上の結果より, 騒音はラットの体重の発育 を減退させ, 飼料の要求率を増加せしめることがわかっ た。更に，その原因のひとつとして，騒音はラットの自 発運動を著明に増加させることから，運動エネルギーと して消費される養分量が, 騒音群はコントロール群より 多いのではないかと推察された。

[発言]

过紘一郎（中外・綜合研） 飼料要求率とは何んのこ とですか？(単位がgになってましたが)。

今井都泰（実中研） 飼料要求率とは, 体重 $1 \mathrm{~g}$ 増加 するために飼料何グラムを要求したかということで，単 位はグラムかまたは数值のみ（無単位）で示されていま 寸。

久保文雄（ヤクルト研） 普通環境（55～65ホン）に 执いて，瞬間的に発生する騒音についての影響について はいかがですか。

今井都泰（実中研）瞬間音または持続時間の短い音 による影響については, 第 $1 ， 5$ 回本研究会等で報告し ています。

笹川祐成 (京大・医) 85 phone の騒音時は常に運 動し， 60 phone の暗騒音時は常に休息状態でしたでし よ5か

今井都泰（実中研） 音刺激によりラットの運動量は 明らかに増加しますが，長期間の連続刺激の場合には運 動量増加のパターンが急性刺激の場合とは異ります。こ の点に関する一部は第74回日本獣医学会 (47.8, 带広) で報告しています。

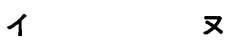

\section{0. 実験用 Beagle の眼底について 第 2 報 色素欠乏 症犬に関する観察}

○福井正信, 安達二朗, 赤地 勇 (中外・綜合研)

清浄閉鎖環境下育成 Beagle 320 頭以上の生産子群中 より 2 例の片側性眼球白色症（Albinismus solum bulbi）を得た。雌雄各 1 例，右及び左眼に発現し，被毛 色調, 鼻端色素沈着は正常である。虹彩色彩は白及び青 色の混じたもので，辺縁において青色々彩濃厚である。 
望膜異常はみられない。瞳孔を通し網膜が赤色調にうか がえる。眼底カメラでの撮影の結果, Tapetal fundus, Non-tapetal fundus の区分明瞭な食肉類の特幑的 像はみられず，一椂に赤色調で脉絡膜血管が透視し得 た。視束乳頭は辺縁部は赤色調で明瞭, 中心の生理的陥 凹部はより白色調で特に異常はない。視・聴覚ともに異 常をみない。MAGRANE（'65）の報告した眼底像（乳 頭辺縁不明瞭などの差はあるが）に類似する。但し虹彩 像は示されていないため比較し得ない。在来白色家猫の 両・片側性虹彩異色症を伴なら眼底は, Beagle での例 飞類似する。虹彩の部分的白色症（正確には青色調も示 す）は対応する眼底部での色素欠損をみせることが観察 された。猫においても視・聴覚異常はみられない。何れ の場合も網・脉絡膜色素欠損とみられる。遺伝的な面は 親・兄弟・子犬群とも現在迄他に異常例をみないため将 来の課題としたい。な和開放環境下育成 Beagle 中に被 毛に黒斑なく，鼻端色素沈着不全を伴なら眼底色素欠之 症をみた。本例虹彩は淡褐色，瞳孔より赤色調眼底を観 察し得る。網膜は Tapetal fundus, Non-tapetal fundus の境界明膫で Tapetal fundus 色調に異常な く, Non-tapetal fundus は赤紫色を呈した。該部静 脉は明瞭に観察された。本症例は網膜, 特に Non-tapetal fundus の色素沈着不全とみられ ROBERTS ら ('65)の German pointer での標準眼底に類似する。但 し何れの場合も剖検例をもたない。この例においても 視・聴覚異常は認めていない。

\section{1. 実験用 Beagle に関する基礎的研究一繁殖コロニ 一にみられた疾病について}

辻紘一郎, $\bigcirc$ 常井和男, 神津正光, 真貝 博, 富永 聰 (中外・綜合研)

〔目的・方法〕1964年より開始した Beagle の繁殖 作業は，1968年より本格的生産に入り，1972年までの 9 年間にその数は延べ 1,300 頭に達した。この間に繁殖コ ロニーに执いて診療した 717例の疾病を診療記録をもと 飞臨床的な見方から, 内科, 外科, 皮フ科, 眼科, 産 科, その他（不慮の事故, 奇型）の 6 つの科に分類し, 疾病の種類と発生の傾向を把握して, 今後の疾病予防に 役立てたいと考㝋た。

〔成績〕 717例のうち, 内科疾病の発生が467例と全体 の $65.9 \%$ で最も多く, 次いで外科73例 $(10.2 \%)$, 皮フ 科70例 $(9.8 \%)$, 眼科 58 例, $(8.0 \%)$, 産科33例 (4. $6 \%$ その他16例 (2.0\%) の順となった。そのうち死 の転帚をとったものは, 内科 81 例, 外科 4 例, 産科 7 例 その他は14例であった。主な症例をあげると，内科では ケンネルコーフ, 肺炎の呼吸器疾患が 438例 (94\%)を 占め, 外科では創傷が 43 例（59\%）であった。皮フ科で
はパピローマ様新生物が 46 例 (66\%), 眼科では瞬膜肥 厚が35例 $(60 \%), \quad$ 産科では難産のための帝王切開が19 例（58\%）を占め，その他では咬殺が 8 例（50\%）であ った。季節別に疾病の発生状況を見ると, 春 $17.8 \%$, 夏 $21.8 \%$, 秋 $46.4 \%$, 冬 $14.0 \%$ の割合で, 秋に多発してい る。また年令別に疾病の発生状況を見ると，哺乳犬20.6 $\%$, 育成犬 $63.4 \%$, 成犬 $16.0 \%$ の割合で育成犬に多発し ている。

〔考察】 9 年間に犬で問題となるジステンパー, 伝染 性肝炎, レプトスピラ症, フィラリア症は, 幸いに 1 例 も発生しなかったが, 呼吸器疾患, パピローマ様新生 物, 瞬膜肥厚, 難産等が予防の方法など解決し得ないま ま残されて扣り，今後の課題である。

\section{2. イヌの甲状腺炎について}

○二木力夫, 高垣善男, 福井正信, 富永 聰 (中外・綜合研)

Tucker（1962） は実験用ビーグル犬127例中 $16.2 \%$ に散在性括よび湎漫性甲状腺炎を病理組織学的に認めて いる。わが国ではまだその報告はないが, 演者らは最 近, 実験用ビーグル犬 124 例を剖検し病理組織学的に検 討したところ，11例 （8.8\%） 飞 Tucker の報告例と ほぼ同様の甲状腺炎を組織学的に認めた。甲状腺炎例は 雄 5 , 雌 6 で $1 \sim 2$ 才のものが 7 例 (63例中), $2 \sim 4$ 才のものが 2 例 (26例中)， 5 才以上では 2 例（5 例 中）であった。甲状腺炎例で, 甲状腺重量が正常例より も重かった例は 1 例にすぎず，それ以外には肉眼的には 異常所見は認められなかった。病理組織学的には, (1) ンパ球・形質細胞および少数の組織球などの細胞浸潤な いしリンパ汇胞の形成のみられる散在性甲状腺炎 (10 例）と，(2)主としてリンパ球・形質細胞の瀮慢性浸潤を 呈する渘漫性甲状腺炎（1例）が認められた。病変の軽 度のものは数力所に細胞浸潤が存在する程度であるが, 強い例ではリンパ沪胞㥞構造ないし胚中心を伴ならリン 八゚沪胞が散在性に形成されて和り，一般にはリンパ球よ りも形質細胞の浸潤が強くみられた。沪胞構造は大部分 崩壊され, 汇胞膠質の減少ないし消失と汇胞の小形化が 著明である。沪胞上皮は著しく腫大し, 胞体は淡明で時 々空胞形成も伴ない, 上皮の石垣状配列が随所に認めら れた。リンパ球・形質細胞や小数の組織球などの汇胞内 浸潤や稀に巨細胞像もみられたが, 上皮の酸好性変性や 間質の線維化は認められなかった。特に甲状腺重量の重 、例の散在性甲状腺炎や湎漫性甲状腺炎例では形質細胞 の浸潤が著明で，ヒトの慢性甲状腺炎像に類似する面が 多い点で興味深い。尚, ビーグル犬の胸腺髄質内にリン パ沪胞様構造が時々みられ，これらの所見と甲状腺炎と の関係を追求したが，特に甲状腺炎と胸腺異常との関係 
は認められなかった。

\section{[発言]}

及川弘（塩野義・油日） Chronic thiroiditis 飞 ついては FDA (Washington DC) では young adu1t Beagle 120\%, Univ. California (Davis) では10 才以上の Beagle で20\%, Pick（'65）は8\%認めてい ます。

三木力夫 (中外・綜合研) 実験用 Beagle 犬の甲状 腺炎は文献的には Tucker (1962) の記載や只今先生が 御指摘された報告例の如く, アメリカでは比較的多く発 生しているょうであります。

Davis の10才以上の Beagle 犬の闸状腺炎と Tucker や吾々が認めた甲状腺炎との比較については, 現在 Davis の詳細な報告をみて和りませんので, この点明らか ではありません。ただ, 文献的に15才令の雄 Boston terrier に橋本病 type の甲状腺炎例報告があります。 この Beagle の甲状腺炎は発生原因が明らかでなく, 組 織像の上で形質細胞の浸潤が強く, 胚中心をもつ多数の リンパ汇胞形成を伴なって括り, 自己免疫疾患を疑ら興 味深い所見であると思われます。

\section{3. ビーグル繁殖コロニーにおけるジステンパーの大量 発生について}

○久木田禧一, 岩城隆昌（日本E DM), 山内忠平 (実中研)

昭和 47 年 2 月から 5 月にわたって, 日本 EDMの芝川 生育場で, ビーグルの育成犬にジステンパー症が大量に 発生した。その発生の状態と経過について増告する。

1. 症状は鼻汁, 咳, 眼脂, 食欲不振, 元気消失, 微熱などに始まり, 重症例では高熱, 食欲廃絶, チック 症状，後銵麻脾なども発現した。発症は全育成犬の $42 \%$ にみられ、これらの $36.5 \%$ が死亡した。死亡例は21日令 から 180日令にみられたが，とくに61日〜90日令の仔1 又に高率にみられた。種犬には 1 例の死亡例もみられな かった。

2. 流行の初期に，すでに予防接種済みのものでも発 病したが, その死亡率は, 接種後10日以内の もので 23 \%，20日までのもので10\%，30日までのもので $5 \%$ 日゙ った。しかし31日以上経過したものでは死亡例はみられ

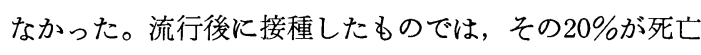
し，非接種のまま経過したものは $95 \%$ 死亡した。

3. 治療は, ジステンパー免疫血清, Domon-L, 抗 生物質及びその他の対症療法で行ったが, 顕著な効果を 示す薬物はなかった。

4. 種犬は 3 回以上の予防接種をしていたが, 抗体価 は 8〜640倍で, 16頭検査した内，12頭が100倍以下と著 しく低かった。育成犬の抗体価も50〜80倍で, 低い傾向
にあった。

5. 病理解剖の結果, 肺は全葉にわたって充血してい た。後稫麻瘦をきたしたイヌでは，大脳皮質および春䯣 にグリア細胞の増殖がみられたが，他には大きな病変は 認められなかった。

\section{[発言]}

中垣 登(塩野義・研） ジステンパーワクチンの接 種時期についてらかがいたい。

久木田禧一（日本E D M) 御質問の趣旨は，「あま りに幼い時期にワクチンの接種を行つては, 仔イヌに免 疫抗体の産生能が無いのではないか」とこの点にあると 推察致します。幼犬の抗体の産生能の発現時期について は, はっきりした事は判りません。しかし, 幼犬でも接 種した群では，予防効果はあるように思います。

富永 聰 (中外・綜合研) ジステンパーの抗体価が 比較的低い成績についての知見並びに和考学がありまし たら扣教え下さい。

久木田禧一(日本EDM) イヌの品種にも問題があ るかもしれないが，当社のイヌは外部から閉鎖された犬 含で飼育されているので, 自然感染の機会が比較的少い ために抗体価は低くなるのではないかと考えます。

内海健二朗（大日本製薬・総合研）ジステンパーワ クチン接種後の抗体価の消失状態をしらべた成績を追加 致します，接種は 3 力月令である。

\begin{tabular}{|c|c|}
\hline 73力月令で & $200 \quad \mathrm{ND}_{50}$ \\
\hline $45 \quad \prime \prime$ & 200 \\
\hline 27 & 126 \\
\hline 25 & $126 \sim \geqq 316$ \\
\hline 17 & $66.6 \sim \geqq 316$ \\
\hline 12 & $\geqq 316 \quad$ "I \\
\hline
\end{tabular}

尚, 接種後 1 力月が経過しても抗体価の上昇のみられ ないこともあった。

\section{4. 実験用 Beagle の歯牙の磨耗について}

福井正信, ○赤池 勇, 安達二朗 (中外・綜合研)

前報（福井ら, '71）の歯牙萠出観察にひきつづき, 閉 鎖清浄環境下育成の所謂 Parasite free beagle に拉 いて歯牙の磨耗を観察した。記環境下で CD 1 固型飼 料により飼育育成した雄 45 頭, 雌32頭，4８2月令を対 象とし（内一部は定期的に 1 年間）計測を行った。測定 は永久歯上顎第 1 切歯の写真撮影により, 計測箇所は歯 冠長 $($ 原錐長を除く $)=a$, 原錐長 $=b$, 歯冠巾 $=c$, 原錐巾 $\mathrm{d}$ とした。のべ 650 歯の計測の結果, $\mathrm{a}$ 測定值 の推移は 3 相に分かれ，4 12月の成長期，40月以後の 歯肉後退期及びその中間の比較的安定な時期に分かれ た。 $\mathrm{b}$ 值は， $4 \sim 12$ 月令迄は変化に乏しく, 以後時間の 
経過に比例してその值は急激に小さくなり磨耗の進行が 観察された。c 值は月令との間に関係をみず，磨耗をみ ない。 $\mathrm{d}$ 值の動きは $\mathrm{b}$ 值のそれとほぼ同様の傾向をみせ た。このため, 上記各計測部位中， $\mathrm{c}$ を基準として各部 との比をとる試みを行った。先ず $\mathrm{a} / \mathrm{c}$ 值の推移は，先き に述べた a の絶対值の動きとほぼ同樣に 3 相に分かれ， 次式

$$
\begin{aligned}
& \mathrm{Y}=794.643+75.275 x-10.258 x^{2}+0.770 x^{3} \\
& (x=\log 1.2 \times 16
\end{aligned}
$$

が得られた。 b/c とついても $\mathrm{b}$ の絶対值の動きとほぼ同 様の傾向で, $\mathrm{Y}=0.279+0.235 x-0.145 x^{2} \quad(x=\log \mathrm{X}$, 何れも Xは月令) を得ている。をた開放環境下育成 Beagle 雄39頭, 雌89頭の計 252 歯を対象としての調査 の結果，その各月令平均值の推移において，閉鎖環境下 育成群とほぼ同様の動きをみせた。82月令迄の観 察で は, 永久歯脱落例には遭遇していない。1又切歯磨耗に よる年令推定は LEBEAU（'66）PIERARD（'67）なぞ, 特に仏国産 Beagle のそれについては ESCURET ら （'69）の報告がみられるが，我々の同年令の Beagle の 磨耗状態との適合率は必ずしもよくなく，彼らの方式に よる年令推定は, 将来より詳細な検討を必要とするとみ られる。

\section{5. 犬の無麻酔下カテーテル採尿法}

○東山 昇, 中田勝久, 山口健二 （塩野義・研）

薬物の尿中排泄量を測るなどの目的のために従来は自 然蓄尿を材料とした。また投与された薬の動きを短い時 間間隔で知る実験などではカテーテルによる採尿がなさ れていたようである。しかしこの方法ではカテーテルの 㭔入に際して麻酔の必要があり, また雌犬では外尿道口 を見やすくする為に胵前庭に小切開を加える必要もあっ た。これらの問題を解決する為にこの実験を行なった。 [実験材料】イ邓は塩野義で繁殖された雑種成犬。力 テーテルはゴム製のネラトン 5 号とポリエチレン製のロ ブネル 8 号を用いた。腔鏡は人用を購入し，筒部を更に 細く改良した。

\section{〔実験成総〕（1）カテーテル挿入に際してイヌは実験台} 上に雌雄とも脊卧位に保定した方が挿入が容易であっ た。(2)纺ラトンの挿入は麻酔下では雌雄全例に可能であ った。無麻醉下では雌犬に全例可能であったが，雄犬に は全例不可能であった。ロブネルの插入は麻醉下, 無麻 酔下のいずれの場合に沶いても雌雄ともに可能であっ た。(3)ロブネルの挿入に要する時間は雄で 1 分, 雌 3 分 で，15分間隔で採尿が可能であった。(4) 1 回/週 $\times 30$ 週 間のロブネル挿入採尿をした雌雄各 2 頭を実験終了後剖 検し，特に尿道と膀胱の肉眼的及び組織学的検索を行っ
たがほとんど異常は認められなかった。

〔腎障害実験への応用〕1又の腎尿細管に特異的に障 害を及ぼす AmphotericinB を投与し以後 1 日 7 回, 3 日間隔で採尿し検査を行なった。BUN 值と血漿クレ アチニン值は投与翌日最高, 以後徐々に元に復した。ク レアチニンクリアランス值は投与翌日最低，3日目より 徐々に回復に向った。PSP は投与翌日各時間とも最低 となり， $2 \mathrm{mg} / \mathrm{kg}$ 投与犬は 3 日目以降 30 分值と 60 分值は 回復したが， $4 \mathrm{mg} / \mathrm{kg}$ 投与犬は完全に回復しなかった。 尿沈渣は上皮細胞と白血球がみられた。尿蛋白は 8 日目 から陰性。

\section{[発言]}

迲紘一郎（中外・綜合研） Nelaton 护よび Robnel の使用の成否の判定規準についてらかがいたい。

東山 昇 (塩野義・研) 犬を無麻酥下, 背卧位に保 定した場合， Nelaton 执よび Robnel catheter が膀 胱内に容易に挿入出来たか否かと, 更に, 十分な量の尿 が採取出来たかどうかと云うことを判定基準とした。 尚, 十分な量の尿が採取出来た犬の採尿直後の剖検によ って膀胱内に残尿が無かったことを確認した。

菅野 茂 (中外・綜合研) 無麻酔, 背位保定で採尿 されたそらであるが，採尿時にあばれないか?。

東山 昇 (塩野義・研) 日頃から良く犬を訓練して いれば，採尿時に暴れることはない。

\section{6. 自家繁殖 Beagle 犬の血液諸検査値}

○内海健二朗, 深川清二, 鶴田耕右, 大西久美雄, 唇巳 熙（大日本製薬・ 総合研)，野田周作（大阪府大農）

Open System で繁殖育成中（第 5 回研究発表会で報 告)の Beagle 犬について血液諸検査值を求めた。

[方法] 2 62 力月令の今 49 頭, 早55頭について昭和 44 年11月～46年 7 月の間に10回採血を行ない, のべす 143 回, ㅇ199回の検查値について検討した。

〔検査項目方法〕は赤・白血球数（ミクロセルカウン ター), ヘマトクリット值 (毛細管法), 血色素量 (シア ン・メトへモグロビン法）拈よび血漿中の総蛋白, アル ブミン, BUN, クレアチニン, グルコース, コレステ ロール, ビリルビン, $\mathrm{Ca}^{++}$, 無機燐, GOT, Al-P, L DH (Auto Analylyzer SMA12/60), $\mathrm{Na}^{+}, \mathrm{K}^{+}$(A AN-206の焰光法), $\mathrm{Cl}^{-}$(AAN-56のロダン鉄法) の19 項目である。

〔成績】 月令ごとに集計し成長にともなら変動をみた ところ, 成長とともに明らかに増加する赤血球数, へマ トクリット值, 総蛋白, $\mathrm{Cl}^{-}, \mathrm{Na}^{+}$; 減少するBUN, 無 機燐， $\mathrm{Al}-\mathrm{P}$; 注とんぞ変動のない群の 3 つのグループ に分かれた。これら変動する項目が安定する時期は 6 〜 
Base-line data in adult* (Beagle dogs)

\begin{tabular}{|c|c|c|c|c|c|}
\hline & \multicolumn{3}{|c|}{ Male } & \multicolumn{2}{|c|}{ Female } \\
\hline & Unit & $\begin{array}{l}\text { Number } \\
\text { of } \\
\text { samples }\end{array}$ & Mean \pm S. D. & $\begin{array}{l}\text { Number } \\
\text { of } \\
\text { samples }\end{array}$ & Mean \pm S. D. \\
\hline Erythrocytes & $\left(10^{4} / \mathrm{mm}^{3}\right)$ & 50 & $623.3 \pm 97.5$ & 90 & $611.1 \pm 84.6$ \\
\hline Leukocytes & $\left(10^{2} / \mathrm{mm}^{3}\right)$ & 51 & $126.1 \pm 47.7$ & 90 & $144.2 \pm 46.2$ \\
\hline Packed cell volume & $(\%)$ & 52 & $43.2 \pm 5.2$ & 90 & $43.2 \pm 5.4$ \\
\hline Hemoglobin & $(\mathrm{g} / \mathrm{dl})$ & 52 & $15.42 \pm \quad 2.1$ & 90 & $15.2 \pm 2.2$ \\
\hline Total protein & $(\mathrm{g} \%)$ & 41 & $6.03 \pm \quad 0.24$ & 73 & $6.1 \pm 0.36$ \\
\hline Albumin & $(\mathrm{g} \%)$ & 41 & $1.49 \pm 0.24$ & 73 & $1.42 \pm \quad 0.15$ \\
\hline Blood urea nitrogen & $(\mathrm{mg} \%)$ & 38 & $15.1 \pm 3.3$ & 70 & $15.9 \pm 4.2$ \\
\hline Creatinine & $(\mathrm{mg} \%)$ & 37 & $0.74 \pm \quad 0.12$ & 65 & $0.7 \pm 0.12$ \\
\hline Glucose & $(\mathrm{mg} \%)$ & 41 & $103.9 \pm 10.3$ & 72 & $104.0 \pm 9.1$ \\
\hline Cholesterol & $(\mathrm{mg} \%)$ & 40 & $178.8 \pm 20.5$ & 72 & $189.0 \pm 30.7$ \\
\hline Bilirubin & $(\mathrm{mg} \%)$ & 41 & $0.12 \pm \quad 0.04$ & 69 & $0.11 \pm 0.03$ \\
\hline Chloride & (meq/liter) & 40 & $111.6 \pm 3.8$ & 72 & $112.3 \pm 3.5$ \\
\hline Sodium & (meq/liter) & 40 & $146.6 \pm 3.5$ & 71 & $146.9 \pm 4.0$ \\
\hline Potassium & (meq/liter) & 40 & $3.96 \pm 0.25$ & 73 & $4.06 \pm 0.32$ \\
\hline Calcium & $(\mathrm{mg} \%)$ & 41 & $9.78 \pm 0.27$ & 72 & $10.0 \pm 0.41$ \\
\hline Inorganic phosphorus & $(\mathrm{mg} \%)$ & 41 & $3.45 \pm 0.47$ & 72 & $3.92 \pm \quad 0.73$ \\
\hline GOT & $(\mathrm{mU} / \mathrm{ml})$ & 42 & $46.9 \pm 11.3$ & 73 & $48.2 \pm 11.1$ \\
\hline AL-P & $(\mathrm{mU} / \mathrm{ml})$ & 41 & $51.4 \pm 17.1$ & 73 & $66.3 \pm 24.9$ \\
\hline $\mathrm{LDH}$ & $(\mathrm{mU} / \mathrm{ml})$ & 41 & $27.1 \pm 14.2$ & 73 & $34.7 \pm 22.5$ \\
\hline
\end{tabular}

*. Over 15 months of age.

15力月令の種々であった。この結果よりこれらの項目が 安定するのは15力月令以後であり，それからが成熟期と 判断した。その成熟期の平均值および標準偏差は表のご とくである。

[考察】 Open System であるため四季の影響を受け ていると考えられる。今後更に検討を加えていきたい。 [発言]

安達二朗 (中外・綜合研) 我々も, 清浄閉鎖環境下 育成ビーグル群の血液性状について検討し, その成績は 電気泳動学会, 本研究会 ('69) に報告いたしました。そ の標準值は一応 300 日令でプラトーになるという成績を 得ました。Bulgin (in door) らも8 月月令で安定す ると報告して括り, 貴報告と若干差がありますが, 飼育 条件（特に感染性疾患）を扣さかせ下さい。

内海健二朗（大日本製薬・総合研）飼育条件はオー
プン・システムであります。冬期の暖房設備は備えてい るが, 夏期の冷房設備は持っていない。空は防虫網を取 付け蚊の侵入を防ぎ，更に室内は電気蚊取器を昼夜（春 〜秋）つけ放している。晴天時は $1 \sim 3$ 時間野外運動場 に放置している。成長にともなう生理変動值がプラトー になる時期 (月令) は我々の成績では15力月令で, 安達 氏らの成績より確に遅れているが，これはコロニーによ る差と考えている。感染性疾患で特に注意を要するのは 肺炎 (ジステンパー様症状) 皮膚炎（アカラス）であ る。前者は日頃の症状観察時で疑しい時は体温測定を行 ない, 発熱時は抗血清による治療を行なっている。後者 は薬浴を定期的に行ない予防の方に力をそそいでいる。 いずれも $2 \sim 5$ 力月令の間に発生する例が多く, それ以 後は外傷以外の疾病の発生はまれである。 